\title{
CONSIDERAȚII PRIVIND POZIȚIA CRONOLOGICĂ ŞI CULTURALĂ A ETAPEI TIMPURII A CULTURII VINČA ÎN TRANSILVANIA
}

DRAGOŞ DIACONESCU, COSMIN IOAN SUCIU

\section{REZUMAT:}

Utilizarea analizei de corespondență, prin luarea în calcul ca variabile caracteristicile morfologice ale ceramicii aparținând culturii Vinča de la Miercurea Sibiului - Petriș și folosirea rezultatelor obținute drept criterii preliminare pentru o abordare bayesiană, demonstrează că intervalul cronologic absolut pentru nivelul II din acest sit corespunde marjei temporale a fazei Vinča B, contrar opiniilor precedente care considerau acest nivel relaționat în mod special cu faza A a culturii Vinča. Lărgirea perspectivei, prin comparația directă, tot prin analiza de corespondență, dintre situl eponim de la Belo Brdo şi situri amplasate în arealul unor localităti transilvănene cum ar fi Miercurea Sibiului, Alba Iulia sau Tărtăria ne arată că în Transilvania există unităţi stratigrafice de fază Vinča A ce corespund acestei faze aşa cum a fost definită în zona Dunării mijlocii. Faza Vinča B din Transilvania, definită în special pe baza materialelor de la Miercurea Sibiului, prezintă disocieri clare de materialul de la acelaşi palier cronologic din situl eponim al culturii, readucând pe masa discuțiilor problematica variantei transilvănene a culturii Vinča.

\section{ABSTRACT: CONSIDERATIONS REGARDING THE CHRONOLOGICAL AND CULTURAL POSITION OF THE EARLY ViNČA CULTURE IN TRANSYLVANIA}

Applying the correspondence analysis method on the morphological characteristics of the early Vinča culture pottery from the Miercurea Sibiului-Petriş site and using the obtained results as prior-estimates for the Bayesian approach shows that the time span of the Vinča layer, labelled as no. II from this site corresponds only to Vinča B phase, contrary to the prior assertions in this regard which saw this layer connected especially to the phase A of the Vinča culture. Enlarging the territory, consequently making the comparison to the eponymous site of the Vinča culture from Belo Brdo and other Vinča sites such as Alba Iulia and Tărtăria allows the conclusion that in Transylvania exists also a Vinča A horizon which totally corresponds to the same phase from the Middle Danube region. The Vinča B stage from Transylvania, defined especially on the basis of the materials from Miercurea Sibiului is rather different than the one from the Middle Danube region, reopening the discussions about a Transylvanian aspect of the Vinča culture.

CUVINTE CHEIE: cultura Vinča, analiză de corespondență, stil ceramic, neolitic mijlociu transilvănean, abordare bayesiană.

KEYWORDS: Vinča culture, correspondence analysis, pottery style, Transylvanian Middle Neolithic, Bayesian approach. 


\section{Introducere}

Cunoscută în literatura de specialitate a secolului al XX-lea ca faza/stadiul Vinča-Turdaș ${ }^{1}$, etapa timpurie a culturii Vinča a fost separată, datorită ultimilor 40 de ani de cercetări arheologice în Transilvania și Banatul românesc, în mai multe entităţi culturale distincte: cultura Vinča, etapa timpurie ${ }^{2}$, cultura Banatului, fazele I, II /grupul cultural Bucovăț/grupul cultural Parța ${ }^{3}$ și cultura Turdaș ${ }^{4}$. Prima entitate culturală este considerată contemporană cu fazele A și B ale culturii Vinča, cea de-a doua cu finalul fazei A și faza B ale culturii Vinča 5 , iar cultura Turdaș văzută inițial ca fiind contemporană cu fazele B și C ale culturii Vinča ${ }^{6}$, a fost paralelizată cu a doua jumătate a fazei Vinča $\mathrm{C}^{7}$.

\section{Discuții privind conceptul cronologico-cultural Vinča - Turdaș}

Situl arheologic de la Turdaș - Luncă este binecunoscut în literatura arheologică în special prin materialele adunate, începând din 1875, prin săpături arheologice și colecționare, de către Zsófia von Torma ${ }^{8}$, materiale ce au fost publicate in extenso de către Márton Roska9 .

Totodată M. Roska este și arheologul care întreprinde în 1910 și săpături arheologice de control stratigrafic în patru puncte diverse ale sitului ${ }^{10}$. Acum 24 de ani, cele mai timpurii elemente din situl de la Turdaş au fost considerate ca fiind situate cronologic pe baza materialelor stratigrafiate provenind din săpătura lui M. Roska şi publicate de acesta, nu mai devreme de faza Vinča C1 ${ }^{11}$. Pe baza publicației din 1941, care oferă doar date de apartenență la situl de la La Luncă pentru materialele din colecția Zsófia von Torma, fără niciun fel de informație stratigrafică, vor fi clădite paralelismele cultural-cronologice dintre situl transilvănean și situl din zona Dunării mijlocii de la Vinča-Belo Brdo.

Săpăturile arheologice efectuate de M. Vasić la Vinča - Belo Brdo, ale căror rezultate au fost publicate în perioada 1932-1936, au dus la crearea mai multor sisteme cronologice pentru acest sit arheologic și totodată pentru cultura Vinča. Autorul cercetărilor arheologice propune șase faze de evoluție ale sitului, numerotate cu cifre romane ( $\mathrm{I}=$ ceramica din gropile de la baza sitului, $\mathrm{II}=\mathrm{ad} .9-8 \mathrm{~m}, \mathrm{III}=\mathrm{ad}$. 7,9-6 m, IV=ad. 5,9-4 m, V=ad. 3,9-2 m, VI=ad. 1,9-0 m) ${ }^{12}$. Popularitatea acestor cercetări este extrem de mare câtă vreme V. G. Childe discută despre acestea încă din 1929 propunând pentru prima dată o cronologie internă pentru situl de la Belo Brdo ${ }^{13}$. În 1939 este propus primul sistem cronologic bazat pe analiza ceramicii din acest sit, sistem care cuprinde cinci etape, etichetate cu litere majuscule de la A până la $E^{14}$. Între adâncimile de 7 și 6 metri este văzută o schimbare treptată a conținutului

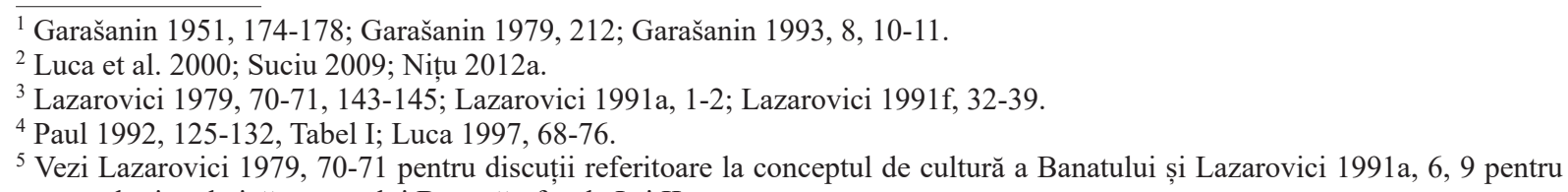

${ }^{5}$ Vezi Lazarovici 1979, 70-71 pentru discuții referitoare la conceptul de cultură a Banatului și Lazarovici 1991a, 6, 9 pentru cronologia relativă a grupului Bucovăț, fazele I și II.

${ }^{6}$ Paul 1992, 125, 131, Table I; Luca 2009, 201 consideră că faza I a culturii Turdaș este contemporană cu stadiul Vinča B2/C, iar faza IV a culturii Turdaș este cuprinsă, respectiv, între sub-fazele C1 și C2 ale culturii Vinča, bazându-se pe sistemul cronologic elaborat de Gh. Lazarovici.

${ }^{7}$ Drașovean 1996, 28, 93-94, 97.

${ }^{8}$ Luca 2001, 26 avansează o teorie conform căreia „o parte destul de însemnată a pieselor din colecție a fost strânsă de la țăranii din Turdaș sau de la cei din Turmaș", localnici care "erau bine plătiți pentru strângerea obiectelor, ei declarau intotdeauna acest lucru - și aceasta este o supoziție -, chiar dacă descoperiseră materialele și în alte locuri". Conform Coltofean 2016, 82-83, Zsófia von Torma achiziționează un vas întreg de la o săteancă din Turdaş, având cunoștință și de existența unei întregi game de obiecte preistorice aflate în posesia locuitorilor Turdașului. Coltofean 2016, 84 arată faptul că printr-o scrisoare datată în 24 ianuarie 1876 Zsófia von Torma îl anunță pe Flóris Rómer că nu i se mai permite să efectueze cercetări arheologice în situl de la Turdaș în mod liber, ci doar în schimbul unor sume de bani. Această situație poate fi un argument conjunctural pentru o acțiune deliberată de achiziții de obiecte declarate ca fiind din situl de la Turdaș, așa cum sustine Luca 2001.

${ }^{9}$ Roska 1941, 7-15, Taf. I-CXLV. Aici trebuie să amintim și contribuțiile științifice ale Zsófiei von Torma numite de unii autori (Luca 2001, 26), dintre care am avut acces, personal, la una dintre ele - Torma 1879.

${ }^{10}$ Roska 1941, 9.

${ }^{11}$ Drașovean 1996, 93-94, 97; sistemul cronologic folosit este cel al lui Gh. Lazarovici, unde etapa C1 este cuprinsă între adâncimile 6-5 m, cote altimetrice care, în sistemul Schier, corespund fazei C2. O încercare de analiza multivariată aplicată pe materialele din săpăturile lui M. Roska din 1910 vede lumina tiparului în 1996 - Lazarovici, Maxim 1996. Din păcate rezultatele acestuia sunt neconcludente, autorii încadrând grupul Turdaș în etapa Vinča B2 (i.e. adâncimea de 7-6 m la Vinča) pe baza unor aserțiuni mai vechi ale primului autor (vezi Lazarovici, Maxim 1996, 224).

${ }^{12}$ Vasić 1936, 1.

${ }^{13}$ Childe 1929, 26-27. Este propusă existența a două etape: Vinča I și Vinča II, separația altimetrică dintre cele două faze fiind făcută la adâncimea de $5,5 \mathrm{~m}$. Printre siturile considerate ca aparținând etapei Vinča I este numit și situl de la Turdaș (Childe 1929, 27, n. 3)

${ }^{14}$ Holste 1939, 2-5. Faza stratigrafică Vinča E este văzută ca fiind ultima etapă pre-metalică din cadrul sitului ce precede ceramică de tip Vatina, fiind paralelizată cu descoperiri de tip Baden în Ungaria de vest și câmpia Tisei (Holste 1939, 16, 
cultural, aspect ce îl face pe F. Holste să definească la acest orizont stratigrafico-altimetric debutul fazei $\mathrm{C}^{15}$.

În 1949, V. Milojčić, plecând de la sistemul lui Holste, îl modifică ușor, precizând mult mai clar conținutul cultural al celor cinci etape, creând totodată o primă sub-diviziune a fazei $\mathrm{B}$ în $\mathrm{B} 1$ și $\mathrm{B} 2^{16}$ și a fazei $\mathrm{C}$, în $\mathrm{C} 1$ și $\mathrm{C} 2$, această din urmă sub-fază fiind văzută la adâncime de $4,5 \mathrm{~m}^{17}$. Totodată V. Milojčić propune ca fazele A și B să fie integrate în etapa veche (timpurie) a culturii Vinča, iar fazele C și D în etapa târzie ${ }^{18}$. În 1951 M. Garašanin propune și el două mari faze pentru cultura Vinča, separate în situl eponim în zona adâncimii de $6,5 \mathrm{~m}$, prima dintre ele fiind numită Vinča-Tordoš (rom. Turdaș), iar cea de-a doua Vinča-Pločnik ${ }^{19}$. De subliniat că linia de demarcație altimetrică dintre cele două faze corespunde celei definită de F. Holste pentru debutul fazei C.

Milutin Garašanin aprofundează subiectul cronologiei culturii Vinča și, în 1979, propune un sistem mult mai complex, unde faza Vinča - Tordoš este împărțită în două sub-faze (I - gropi și cca $8 \mathrm{~m}$ adâncime și II - cca 8-6,5 m adâncime), pe care le echivalează etapelor A și B1 din cronologia propusă de V. Milojčić; sub-faza II este considerată ca posibil de divizat în alte două etape (IIa și IIlb), fiind urmată de faza Gradac (cca 6,5-6 m adâncime, echivalată sub-fazei B2 la Milojčić) ce se intercalează între cele două mari faze definite anterior în $1955^{20}$. Faza Vinča-Pločnik este și ea subiectul unui proces de etapizare, fiind create sub-fazele I (cca 6-4,1 m adâncime), IIa (cca 4,1-3,48 m adâncime) și IIb (cca 3,48-2,98 m) care sunt paralelizate, corespunzător, cu sub-etapa B2-C [sic!] și fazele C și D din cronologia lui Milojčićc ${ }^{21}$. Autorul sârb își păstrează această opinie și mai târziu ${ }^{22}$, în două studii cuprinzătoare, în cel de-al doilea reluând problema corespondenței dintre cele două sisteme cronologice ale culturii Vinča, deja clasicizate la data redactării articolului în cauză ${ }^{23}$.

Pentru teritoriul românesc, cel mai influent sistem cronologic pentru cultura Vinča este cel realizat de Gh. Lazarovici în 1979, sistem cronologic ce folosește ca bază de plecare sistemul propus de V. Milojčić. Astfel, faza A este sub-divizată în trei sub-faze (A1, A2, A3), faza B deasemenea (B1, B1/B2, B2), fiind văzut și un fenomen de „retardare" numit B2/ $\mathrm{C}^{24}$. Fazele târzii sunt clasificate foarte simplu sub nomenclatura de $\mathrm{C}$ și D. Pentru aceste faze târzii ale culturii Vinča trebuie să amintim sistemul propus de D. Berciu care, plecând tot de la sistemul lui Milojčić împarte faza C în sub-fazele C1, C2, C3/tranziție C-D și faza D în sub-fazele D1 și D2 ${ }^{25}$. Pentru regiunea Banatului este propus de către F. Drașovean un sistem cronologic bazat și la nivel declarativ pe cel al lui V. Milojčić, pentru etapa târzie a culturii Vinča, mai precis pentru faza $\mathrm{C}$ a acesteia, divizată în două sub-faze $\mathrm{C} 1$ și $\mathrm{C} 2^{26}$.

O sinteză excelentă a sistemelor cronologice propuse pentru cultura Vinča este cea realizată de W. Schier ${ }^{27}$. În mod fericit autorul german include în această discuție și propunerea proprie, bazată pe analiza multivariată a ceramicii vinčiene, în special din situl eponim. Prin realizarea unui tabel comparativ între sistemele cronologice propuse de-a lungul timpului de către Menghin, Holste, Milojčić, Garašanin, Berciu, Dimitrijević, Lazarovici, Chapman,

21). Conform lui Miločić 1949, 73 această fază este caracterizată prin descoperiri aparținând Epocii Cuprului, mai precis de tip Baden-Kostolac.

${ }^{15}$ Holste 1939,4

${ }^{16}$ Milojčić 1949a, 72-74.

${ }^{17}$ Milojčić 1949a, 73.

${ }^{18}$ Milojčić 1949a, 74, tabelul sinoptic.

${ }^{19}$ Garašanin 1951, 173. Fazei Vinča-Tordoš îi este atribuit, din afara teritoriului iugoslav la acel moment și situl de la Turdaș, cu toate cele trei niveluri surprinse aici (Garašanin 1951, 183).

${ }^{20}$ Garašanin 1979, 152.

${ }^{21}$ Garašanin 1979, 152.

22 Garašanin 1982, 88.

${ }^{23}$ Garašanin 1993, 8. Aici trebuie să discutăm problematica ridicată de Whittle et al. 2016, 4, n. 2 conform căreia: „Unfortunately, Garašanin (1979.152) misunderstood Milojčić's subdivision, maintaining that, according to the latter, the transition between Vinča B2 and C would occur around a depth of $5 \mathrm{~m}$ at Belo Brdo, instead of at $6 \mathrm{~m}$ as Milojčić had clearly stated. This led to several decades of mismatch between the two typological systems, since researchers more familiar with the Garašanin scheme consistently 'translated' the phase Vinča-Pločnik I back into the Milojčić scheme as , Vinča B2-C "instead of correctly „Vinča C”. În 1951 M. Garašanin spune foarte clar că delimitarea dintre fazele Turdaș și Pločnik este cel mai probabil la adâncimea de 6,5 m. În 1979, la orizontul altimetric de 6,5-6 m el introduce faza Gradac, pe care o vede contemporană cu etapa B2 din cronologia lui Milojčić. În lucrarea Milojčić 1949a, 72 etapa B1 este văzută între metri 8 și 7. Pentru etapa B2, Milojčić 1949b, 276 precizează adâncimea de 6,8 m pentru reconstrucția așezării din această fază. V. Milojčić vede o cezură în dezvoltarea sitului la adâncimea de $6 \mathrm{~m}$ (Milojčić 1949b, 266). M. Garašanin vede la $6.5 \mathrm{~m}$ o modificare a stilului ceramic, de aceea introduce în schemă faza Gradac. Intercalarea în schema cronologică a lui Milojčić, în mod arbitrar, de către M. Garašanin, a sub-fazei B2-C și echivalarea sub-fazei Vinča-Pločnik I cu aceasta (vezi Garašanin 1979, 152), este elementul care creează confuziile și decalajele de care vorbesc mai titrații nostri colegi.

${ }^{24}$ Lazarovici 1979, 80. Orizontul A1 este considerat sporadic la Vinča (Lazarovici 1979, 76, Tab. 7), iar orizonturile A3, B1/B2 și B2/C sunt văzute în situl de la Belo Brdo ca hiatus-uri.

${ }^{25}$ Berciu 1961, 72, 90.

${ }^{26}$ Drașovean 1996, 28.

${ }^{27}$ Schier 1995, 302-320. 
Parzinger, Schier este oferită posibilitatea echivalării cât mai corecte între diversele faze şi sub-faze ale culturii Vinča, existente în cadrul sistemelor cronologice respective ${ }^{28}$. Analiza de corespondență efectuată de către W. Schier pe ceramica din situl de la Belo Brdo dintre 9,3 și 5 m adâncime oferă imaginea existenței a 7 faze, fiind vizibile şi două zone de cezură/hiatus între unitățile de analiză reprezentate de gropi și niveluri altimetrice/stratigrafice. Prima zonă de acest gen este dispusă între faza 1 (reprezentată de groapa Z, atribuită culturii Starčevo - Criş) și faza 2a și a doua între faza 5c și faza 6 unde pachetul stratigrafic corespunzător adâncimii 6,5 m este reprezentativ, marcând trecerea de la faza B2 la faza C1 în cadrul așezării de tip tell de aici ${ }^{29}$. Soliditatea demersului întreprins de W. Schier ne-a convins să folosim în studiul prezent, în dorința de analizare a descoperirilor transilvănene pretabile, sistemul cronologic al culturii Vinča propus de acesta.

Similitudini între materialele de la Vinča și cele de la Turdaș au fost văzute încă de la începutul secolului al XX-lea, moment în care publicarea acestor situri era la un stadiu preliminar ${ }^{30}$.

Pe baza analogiilor formale dintre materialele publicate de la Vinča (1936) și Turdaș (1941), M. Garašanin își elaborează sistemul cronologic pentru cultura Vinča, în care, aşa cum spuneam mai sus, etapa timpurie (pînă la 6,5 m adâncime) este numită Vinča-Tordoš/Turdaș. În 1993, M. Garašanin, cunoscând absența datelor stratigrafice viabile pentru materialele din colecția Zsófia von Torma ${ }^{31}$, încadrează totuşi situl de la Turdaş (orizonturile prePetrești) în intervalul cuprins între etapele Vinča - Tordos Ia-b=Vinča A2-A3 și faza Gradac=Vinča B2 ${ }^{32}$. Utilizând comparația cu sistemul propus de W. Schier, încadrarea propusă de cercetătorul sârb este între fazele A2-C1.

Sistemul cronologic propus de M. Garašanin și descoperirile de la Turdaș fac ca istoriografia românească să folosească termenele de cultură Turdaş, Turdaş-Vinča sau Vinča-Turdaş în același timp, fără o separație clară între aceste concepte ${ }^{33}$. Pentru prima dată, în 1965, este propus termenul de cultură Turdaş, ca entitate clar definită, când Iuliu Paul afirma că: „Prin urmare, credem ca nu greșim dacă afirmăm că, pe teritoriul Transilvaniei, mai precis pe valea Mureșului central şi într-o regiune limitrofă, avem de-a face cu un aspect cultural care prin totalitatea formelor sale de manifestare de pe acest teritoriu justifică folosirea unui termen diferit. De aceea opinăm pentru folosirea termenului de Turdaş, pentru definirea acestui aspect cultural, fără a pune însă semnul egalității între acesta și cultura Vinča în ansamblul ei." "34 Mai târziu, același autor precizează și mai clar opinia sa privitoare la aceasta cultură, oferind și o periodizare internă în trei faze (I-III) ${ }^{35}$. Incadrarea nivelurilor pre-Petrești din situl de la Turdaș este în accepțiunea lui I. Paul cuprinsă între Vinča B1-C1 $1^{36}$ (i.e. Vinča B1-faza Vinča C1/prima jumătate a fazei C2 în sistemul cronologic Schier).

Foarte interesant este faptul că opinia din 1965 a lui I. Paul legată de o dezvoltare independentă a culturii Vinča în arealul transilvănean ${ }^{37}$, argument folosit pentru utilizarea denominativului de Turdaș pentru această manifestare, își

\footnotetext{
${ }^{28}$ Schier 1995, Abb. 146.

${ }^{29}$ Schier 1995, 207, Abb. 114; vezi desemenea Schier 2000, 192, fig. 4.

${ }^{30}$ Vasić 1910, 35, n. 4, citând din studiul Schmidt 1903.

${ }^{31}$ Garašanin 1993, 16.

${ }^{32}$ Garašanin 1993, 17.

${ }^{33}$ Vlassa 1967, 407, 419 (autorul folosește însă și conceptul de cultura Turdaş-Vinča la p. 409 sau cel de cultură Vinča-Turdaş la p. 408, pe lângă cel de cultura Turdaș); Lazarovici 1979, 71, n. 20 utilizează termenul de grup Turdaș (aici autorul indica pe Kalicz, Makkay 1977, 94, Tab. 2 ca promotori ai conceptului de grup Turdaş; verificarea sursei citării ne obligă să menționăm ca cei doi autori nu folosesc deloc acest termen, iar în Tab. 2 pentru Transilvania centrală nu este indicată nici o entitate culturală mai târziu de Körös-Kultur); Luca 1986, 53 menționează grupele transilvănene Iclod, Turdaș și Tăulaș; Lazarovici 1991c, 9-10, folosește termenii de cultură Turdaș și de grup Turdaș; Lazarovici, Kalmar-Maxim 1991b, 122132, definesc aspectul Turdaș continuând însă utilizarea termenului de cultură Vinča-Turdaș (vezi p. 125 din respectivul studiu); Lazarovici 1991b, 115-120 definește aspectul Tăulaș ca aspect cultural al culturii Turdaș (vezi p. 115); Dumitrescu 1984, 19 folosește termenul de cultură Turdaş chiar dacă uzitează conceptul de cultură Vinča-Turdaş în tot restul studiului); Draşovean 1996, 93 și Luca 1997, 68-77 utilizează doar conceptul de cultură Turdaş, discutând și inadvertența terminologiei de tỉp Vinča-Turdaș și plasând începuturile culturii Turdaș la orizont de, cel mai devreme, Vinča B2; Maxim 1999, 81-87 folosește termenul de grup Turdaş; Luca 2001, 95-143 cu o discuție mult mai detaliată asupra orizontului vinčian timpuriu din Transilvania, precum și a influențelor liniare din acelaşi spațiu, face uz din nou de termenele Vinča și Turdaş; Lazarovici, Lazarovici 2006, 568-596, elementele de tip Tăualaș sunt încorporate în grupul Turdaş, utilizându-se chiar termenul de grup Turdaș-Tăulaș.

${ }^{34}$ Paul 1965, 298. Autorul susține că nu se poate vorbi despre existența unei faze vechi Vinča A în Transilvania, oferind ca exemplu situl de la Tărtăria unde, în stratul inferior al aşezării, nu s-au identificat materiale mai vechi de etapa B1 a culturii Vinča. De asemenea I. Paul afirmă că „pătrunderea purtătorilor culturii Vinča spre centrul Transilvaniei” se face la fază ceva mai târzie, subliniind și o dezvoltare independentă față de centrul de origine, în noul spațiu, care nu îi modifică „structura sa intimă" dar îi imprimă o linie de dezvoltare culturală distinctă, comparativ cu arealul din jurul stațiunii eponime.

${ }^{35}$ Paul 1981, 224-225, Abb. 18, 231, 233; Paul 1992, 131, Tabel 1 și 2. Autorul paralelizează Turdaș I cu Vinca B1, Turdaș II cu Vinca B2 și Turdaș III cu Vinca C.

${ }^{36}$ Paul 1981, 225 and Abb. 21.

${ }^{37}$ Paul 1965, 298.
} 
găsește ecou în opinii exprimate la câțiva ani mai târziu. M. Garašanin discută despre mai multe facies-uri/variante regionale (mai precis șase) ale culturii Vinča ${ }^{38}$ și anume varianta clasică/sârbească, varianta sud-moravă, varianta kosovară, varianta bosniacă, varianta transilvăneană și varianta oltenească. J. Chapman reia și el acest subiect propunând cinci secvențe regionale: Serbia și Macedonia, Vojvodina, Bosnia de nord, Oltenia și Transilvania ${ }^{39}$. Astfel cei doi autori susțin existența unei variante regionale a culturii Vinča în Transilvania, M. Garašanin considerându-i încheiată evoluția la nivelul fazei $\mathrm{Gradac}^{40}$. John Chapman se raliază la ideea prezentă în propunerea făcută de I. Paul în 1965, independent de aceasta, fără să folosească/citeze studiul cu pricina, sugerând pentru cultura Vinča în Transilvania o evoluție în trei faze (I-III) ${ }^{41}$, ultima dintre ele, III fiind văzută ca reprezentată de sfârșitul etapei Tărtăria II și etapa Tărtăria III și etapa Pianul de Jos I și contemporană cu faza D din situl eponim²

După demersul științific datorat lui Iuliu Paul, cultura Turdaș a "suferit" o contracție culturală și cronologică, prin cercetările întreprinse, în special, în siturile de la Orăștie-Dealul Pemilor și Turdaș-Luncă de către S. A. Luca. Astfel, cultura Turdaș este împărțită în patru faze, faza I a culturii Turdaș fiind văzută contemporană cu etapa Vinča B2/C, iar faza IV a culturii Turdaș este cuprinsă între sub-fazele C1 și C2 ale culturii Vinča ${ }^{43}$ (sistem cronologic Lazarovici care, translatat în sistemul Schier, înseamnă sfârşit de fază C1/început de C2 - tranziție C2C3). Contracția culturală este, în fapt, considerarea fazelor Turdaș I și Turdaș II definite de I. Paul ca aparținând culturii Vinča, faza timpurie ${ }^{44}$ și transformarea practic a fazei Turdaș III (cronologie Paul) în "noua" cultură Turdaş, separată la rândul ei în patru faze.

Inadvertența dintre opiniile exprimate de M. Garašanin, I. Paul, F. Drașovean și S.A. Luca referitoare la cronologia sitului de la Turdaș este rezolvată parțial de datele ${ }^{14} \mathrm{C}$ existente la acest moment pentru situl de la Turdaş ${ }^{45}$. Sumele mărginite ale celor două etape bazate pe cele șase date publicate până acum sunt ilustrate în Fig. 1 și arată că suma mărginită a datelor atribuite culturii Turdaș este contemporană cu zona mediană a sectorului cel mai consistent atribuit fazei Vinča C, iar suma mărginită a datelor atribuite culturii Petrești corespunde celei de-a doua jumătăti a fazei Vinča D și chiar mai târziu ${ }^{46}$. În consecință la acest moment nu există nici un argument de cronologie absolută pentru o încadrarea a sitului de la Turdaș mai devreme de sub-faza C2 a culturii Vinča.

În acest fel, opiniile deja exprimate în literatura românească acum mai bine de 20 de ani legate de inadvertența folosirii în continuare a conceptului de fază Vinča - Turdaș pentru etapa timpurie a culturii Vinča ${ }^{47}$, capătă argumente din ce în ce mai solide din partea datelor de cronologie absolută, câtă vreme situl transilvănean considerat reprezentativ este contemporan cu etapa târzie a culturii Vinča, numită și Vinča - Pločnik.

\section{Siturile aparținând etapei timpurii a culturii Vinča din Transilvania}

Descoperirile arondate culturii Vinča din Transilvania au fost încadrate, folosind metoda comparativă, în etapa timpurie a culturii Vinča în intervalele definite de sub-fazele Vinča A1-B1 ${ }^{48}$ sau A2-B1 ${ }^{49}$. Mai recent, cel mai vechi orizont Vinča din Ardeal era considerat a fi sub-faza A3 ${ }^{50}$.

Siturile atribuite culturii Vinča sunt concentrate pe cursul mijlociu al Mureșului și pe văile afluenților săi sudici (vezi Fig. 2). Ele vor fi enumerate în ordine alfabetică după cum urmează: Aiud-Cetățuie ${ }^{51}$, Alba-Iulia-Lumea

\footnotetext{
${ }^{38}$ Garašanin 1979, 181-194 și Garašanin 1982, 124-126.

${ }^{39}$ Chapman 1981, 21-22, 29-30.

${ }^{40}$ Garašanin 1993, 17.

${ }^{41}$ Chapman 1981, 22.

${ }^{42}$ Chapman 1981, 22.

${ }^{43}$ Luca 2009, 201, Tab. 1.

${ }^{44}$ Vezi în special Luca et al. 2000, dar și Luca 2009, 201, Tab. 1

${ }^{45}$ Conform Luca et al. 2019, 4-5, tab. 1 există două date ${ }^{14} \mathrm{C}$ pentru nivelul Petrești (RoAMS 47.40 și RoAMS 45.40) şi patru date ${ }^{14} \mathrm{C}$ (RoAMS 44.40, RoAMS 43.40, RoAMS 46.40, RoAMS 42.40) pentru nivelul Turdaș. Datele RoAMS 45.40 și 47.40 au mai fost publicate de două ori în Luca et al. 2018, 116-117, Table 1 și în Luca et al. 2017a, 36, Tabel 1, iar datele 42.40, 46.40 tot de două ori în Luca et al. 2017b (cf. Luca et al. 2017a, 36, Tabel 1, n. 5).

${ }^{46}$ Conform Whittle et al. 2016, (fig. 37).

${ }^{47}$ Drașovean 1996, 94; Luca 1997, 72-73.

${ }^{48}$ Luca et al. 2000, 49-50 consideră elementele Vinča timpurii din acest areal aproape identice cu cele din aria inițială de definire al acestui orizont - i.e. zona Dunării.

${ }^{49}$ Luca 1997, 75.

${ }^{50}$ Luca 2009, 201, tab. 1.

${ }^{51}$ Ciugudean 1978, 49, fig. 5/6; Luca et al. 2000, 37-38; Luca 2001, 98-99; Ciută 2004, 32; Suciu 2009, 64; Niţu 2012a, 30, nr. cat. 1.
} 


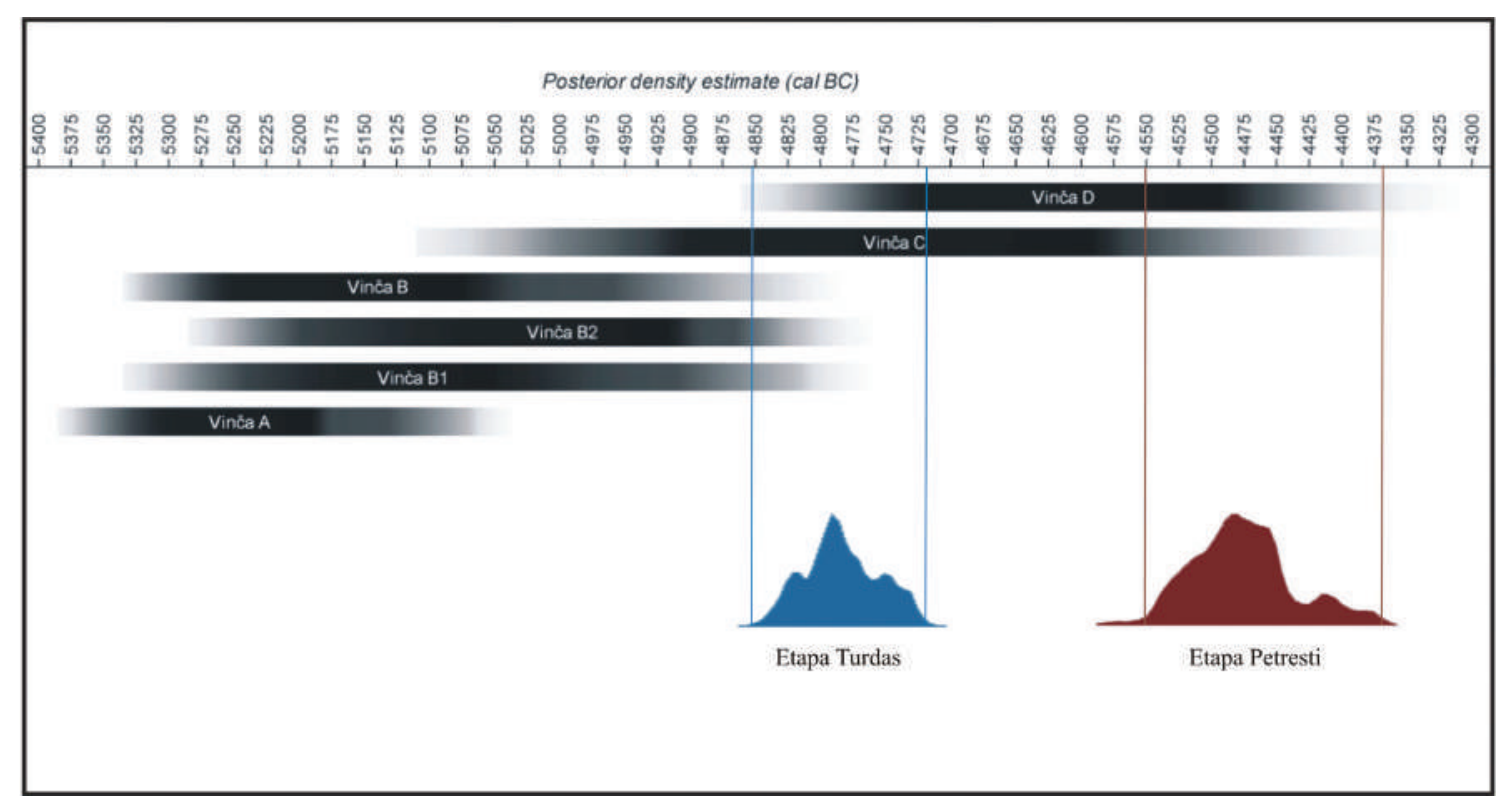

Figura 1. Cronologia nivelurilor atribuite culturilor Turdaș și Petrești din situl de la Turdaș - Luncă (prelucrare după Whittle et al. 2016, fig. 37).

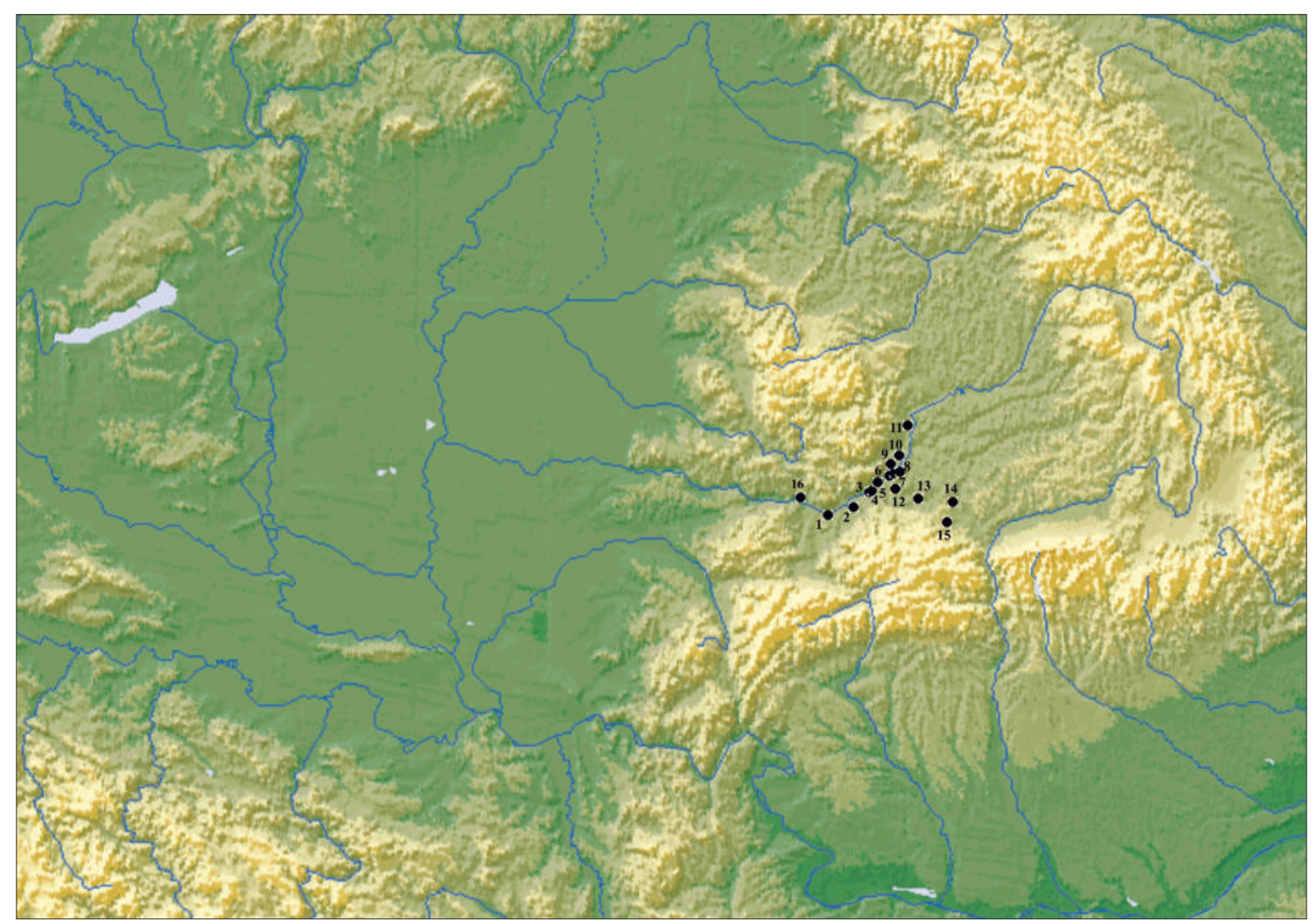

Figura 2. Harta siturilor certe aparținând culturii Vinča în Transilvania: 1) Râpaș; 2) Romos; 3) Balomiru de Câmp; 4) Tărtăria; 5) Vurpăr; 6) Oarda de Jos; 7) Limba; 8) Șeușa; 9) Alba Iulia; 10) Sântimbru; 11) Aiud; 12) Sebeș Alba; 13) Miercurea Sibiului; 14) Ocna Sibiului; 15) Orlat; 16) Şoimuş. 
Nouă $\breve{c}^{52}$, Balomiru de Câmp-Gura Văii Cioarei ${ }^{53}$, Cașolț-Poiana din Pisc ${ }^{54}$, Cerișor-Cauce ${ }^{55}$, Hunedoara-Biserica Sf. Nicolae $^{56}$, Limba - Bordane ${ }^{57}$, Limba - Șesul Orziii ${ }^{58}$, Limba-Vărar ${ }^{59}$, Limba - Vărăria ${ }^{60}$, Miercurea Sibiului-Petriș ${ }^{61}$, Miercurea Sibiului-Luncă (Pustia) ${ }^{62}$, Miercurea Sibiului-Gară ${ }^{63}$, Miercurea Sibiului-Valea Gârbovei ${ }^{64}$, NandruPeștera Curată ${ }^{65}$, Oarda de Jos-Dublihan ${ }^{66}$, Ocna Sibiului-Fața Vacilor ${ }^{67}$, Orlat-Poduri ${ }^{68}$, Râpaș-Grivoni/Ferma ${ }^{69}$, Romos-Făgădau ${ }^{70}$, Sântimbru-La Țărmure/La Ierugă ${ }^{71}$, Sebeș Alba-Podul Pripocului ${ }^{72}$; Șeușa-La cărarea morii ${ }^{73}$, Șoimuș - La Avicola/Ferma 2 ${ }^{74}$, Tărtăria - Gura Luncii ${ }^{75}$; Tărtăria - Gura Luncii/Gura Văii Cioarei ${ }^{76}$; Tărtăria Pietroșița $a^{77}$; Vurpăr ${ }^{78}$. O analiză critică a apartenenței acestor situri la cultura Vinča a fost făcută deja ${ }^{79}$, patru din aceste situri nebeneficiind de suficiente argumente pentru a fi atribuite acestui palier cronologic și cultural: Caşolț - Poiana din Pisc, Cerișor - Peștera Cauce, Hunedoara - Biserica Sf. Nicolae și Nandru - Peștera Curată.

Cercetările arheologice sistematice de la Miercurea Sibiului-Petriș și cele preventive și sistematice la Alba Iulia

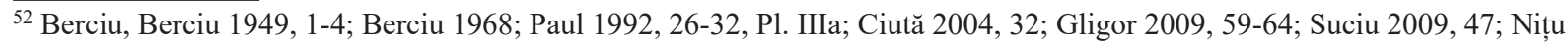
2012a, 30-31, nr. cat. 2. Foarte interesant este că în Luca et al. 2000 și în Luca 2001, 97-124 (textele sunt similare în ambele surse bibliografice) așezarea neolitică de la Lumea Nouă nu este considerată ca făcând parte din siturile cu elemente Vinča timpurii, chiar dacă materialele publicate în Berciu, Berciu 1949, fig. 3-5, 11, prezintă elemente tipice pentru orizontul timpuriu vinčian (?). În schimb, situl de la Aiud, pe baza a trei fragmente, unul singur ilustrat și care nu prezintă elemente tipice, este integrat în respectiva categorie.

${ }^{53}$ Vlassa 1976, 114-117; Popa 2000, 18, nr. cat. 1.1.1, Pl. XII/1-3; Luca et al. 2000, 38; Luca 2001, 99-100; Ciută 2004, 32; Suciu 2009, 65; Popa 2011, 672-673, nr. cat. 5; Nițu 2012a, 31, nr. cat. 3.

${ }^{54}$ Paul 1960, 116 și fig. 6/10; Suciu 2009, 66; Nițu 2012a, 37, nr. cat. 1 - autoarea include acest sit în categoria siturilor incerte pe baza re-evaluării proprii întreprinse pe materialul din situl de la Caşolț, aflate în Muzeul Național Brukenthal (vezi Nițu 2014, 96).

${ }^{55}$ Luca et al. 2000, 38; Luca 2001, 100; Suciu 2009, 68; Nițu 2012a, 37, nr. cat. 2 - autoarea include de asemenea acest sit în categoria celor incerte, câtă vreme în Luca, Roman, Diaconescu 2004, 103, foto 26 încadrează materialele vizate de Suciu 2009 nivelului II atribuit culturii Turdaș. Respectivele fragmente ceramice decorate cu bandă punctat incizată se asociază cu ceramica pictată de tip Tăualaș. De subliniat opinia tranșantă din Roman 2008, 27 care, referindu-se la cultura Vinča, susține că urme ale acestei culturi nu au fost identificate în peșterile din sud-vestul Transilvaniei, areal în care este situată și Peștera Cauce.

${ }^{56}$ Luca et al. 2000, 39; Luca 2001, 100; Suciu 2009, 70; Nițu 2012a, 37, nr. cat. 3 - autoarea include și acest sit în categoria siturilor incerte. Aceste materiale, plasate la debutul anilor 2000 ca mostre în dulapurile sălii de cursuri de la subsolul clădirii Facultăţii de Litere, Istorie și Jurnalistică pe atunci, din Sibiu, nu prezentau nici un element morfologic caracteristic etapei timpurii a culturii Vinča, așa cum nu prezintă nici cele descoperite de curând de echipa coordonată de dr. Sorin Tincu în cadrul cercetării preventive a respectivului monument/obiectiv arheologic (infomație amabilă Sorin Tincu).

${ }^{57}$ Berciu, Berciu 1949, 20; Luca et al. 2000, 39; Luca 2001, 101; Ciută 2004, 32; Mazăre 2005, Tabel 1; Colesniuc 2014, 53, fig. 18; Suciu 2009, 72-73, 75-80; Nițu 2012a, 31, nr. cat. 4.

${ }^{58}$ Mazăre 2005, Tabel 1; Suciu 2009, 75-76; Nițu 2012a, 31, nr. cat. 5.

${ }^{59}$ Berciu, Berciu 1949, 20; Ciută 2004, 32; Suciu 2009, 72-73, 79-80; Niţu 2012a, 32, nr. cat. 6.

${ }^{60}$ Ciută 2004, 32; Suciu 2009, 80; Nițu 2012a, 32, nr. cat. 7. Conform schiței topografice din Ciută 2009, 340, fig. 3 siturile din punctele Bordane, Șesul Orzii și Vărăria sunt situate pe aceeași unitate de relief, constituindu-se de fapt într-un singur sit (vezi și Ciută et al. 2016, 19, fig. 6).

${ }^{61}$ Luca et al. 2000, 40-42; Luca 2001, 103-105; Ciută 2004, 32; Suciu 2009, 87-137; Nițu 2012a, 32, nr. cat. 8.

${ }^{62}$ Luca et al. 2008b; Suciu 2009, 135-137; Nițu 2012a, 33, nr. cat. 9.

${ }^{63}$ Suciu 2009, 137-138, fig. 207. Acest sit nu este inclus în repertoriul propus de Niţu 2012a.

${ }^{64}$ Luca et al. 2013, 55. Situl este numit și Miercurea Sibiului II.

${ }^{65}$ Luca et al. 2000, 42; Luca 2001, 106; Niţu 2012a, 38, nr. cat. 4 - autoarea include şi acest sit în categoria celor incerte, având în vedere faptul că atribuirea culturală se face pe baza unui singur fragment ceramic.

${ }^{66}$ Rustoiu 2001, 55, p. I/2, 13, pl. II/6, 8; Nițu 2012a, 33, nr. cat. 10.

${ }^{67}$ Suciu 2009, 141; Nițu 2012a, 33, nr. cat. 11; Nițu 2014.

${ }^{68}$ Luca, Părean 1995-1996, 31-32; Luca et al. 2000, 42; Luca 2001, 105; Suciu 2009, 142-143; Nițu 2012a, 33-34, nr. cat. 12.

${ }^{69}$ Nițu 2012a, 13, 34, nr. cat. 13; Whittle et al. 2016, fig. 26; Rogozea 2016, 136, n. 55

${ }^{70}$ Luca 1995-1996; Luca et al 2000, 42-45; Luca 2001, 106-111; Suciu 2009, 144-146; Nițu 2012a, 34, nr. cat. 14.

${ }^{71}$ Ciugudean 1979, pl. 11/4,5; Luca et al. 2000, 45-46; Luca 2001, 111; Suciu 2009, 146-147 (scris Sntimbru [sic!]); Nițu 2012a, 34-35, nr. cat. 15.

${ }^{72}$ Popa, Totoianu 2001, 34-35, pl. 1; Ciută 2004, 32; Nițu 2014, 35, nr. cat. 16

${ }^{73}$ Ciută 2004, 29-30, fig. 1; Suciu 2009, 147-148; Nițu 2012a, 35, nr. cat. 17.

${ }^{74}$ Nițu 2012a, 35-36, nr. cat. 18 - autoarea atribuie situl fazei C a culturii Vinča pe baza celor afirmate de Drașovean-Rotea 1986, 20; Ștefan, Petcu, Petcu 2013.

${ }^{75}$ Horedt 1949; Vlassa 1963; Luca et al. 2000, 46; Luca 2001, 111-112; Paul 2011; Suciu 2009, 148-163; Niţu 2012a, 36, nr. cat. 19; Luca 2016.

${ }^{76}$ Rogozea 2016.

${ }^{77}$ Ghenescu, Sana, Ștefu 2000, 82-83; Nițu 2012a, 36, n. 2, nr. cat. 20; Rogozea 2017. Conform lui Ghenescu, Sana, Ștefu 2000, 82 situl de la Pietroșița se află amplasat ,pe terasa situată imediat la E de așezarea neolitică de la Gura Luncii, în dreapta căii ferate Vințu de Jos - Deva”. Comparând această situație cu imaginea din Rogozea 2017, P1. 1/1, 2 constatăm că situl 10b este unul și acelaşi cu cel identificat în anii 2000 și alocat toponimului Pietroșița.

${ }^{78}$ Luca et al. 2000, 46-47; Luca 2001, 112-113; Suciu 2009, 164; Nițu 2012a, 36-37, nr. cat. 21.

${ }^{79}$ Nițu 2012a, 30-38. 
- Lumea Nouă sau Tărtăria - Gura Luncii oferă un cadru suficient de solid pentru o încercare de reconsiderare a orizontului timpuriu al culturii Vinča din arealul sud-transilvănean. Din păcate, situri arheologice în care s-au întreprins cercetări arheologice cum ar fi Tărtăria-Gura Luncii, Ocna Sibiului - Fața Vacilor, Romos - Făgădău, Șoimuș - La Avicola nu au material publicat corespunzător, în anumite cazuri lipsindu-le și apartenența la unități stratigrafice clare, pentru a fi utilizat într-o analiză multivariată. Totuși, publicarea unor complexe aparținând culturii Vinča, din cercetările preventive efectuate în zona teraselor din stânga Mureșului de la Tărtăria (siturile/ punctele de la Gura Luncii/Gura Văii Cioarei și Pietroșița/sit 10b - vezi Fig. 3) oferă materiale pretabile pentru o analiză de acest gen.

Dintre cele patru obiective arheologice care ne oferă date viabile (Miercurea Sibiului, Alba Iulia și cele două puncte de la Tărtăria), situl de la Petriș, datorită muncii depuse de Florina Maria Nițu și Cosmin Suciu, oferă cel mai bun set de date pentru o analiză de corespondență (correspondence analysis prescurtat $C A$ ) a elementelor morfologice ale ceramicii vinčiene și, în consecință, constituie nucleul central al analizei noastre de mai jos.

\section{Studiu de caz: Miercurea Sibiului-Petriș}

Situl de la Miercurea Sibiului - Petriș este situat în partea sudică a bazinului hidrografic al Mureșului mijlociu, pe terasa stângă, neinundabilă a pârâului Secaș, la jumătatea distanței dintre Miercurea Sibiului și Miercurea Băi (Fig. 4). După 14 ani de cercetări arheologice în acest sit (1997-2010 - vezi Fig. 4 pentru arealul cercetat), două teze de doctorat ce au vizat nivelul habitațional aparținând culturii Vinča au fost elaborate de către Cosmin Ioan $\mathrm{Suciu}^{80}$ şi Florina Maria Niţu ${ }^{81}$.

Referiri la descoperirile aparţinând culturii Vinča au fost făcute, pe scurt, în mai multe studii, nivelul Vinča fiind desemnat prin cifra romană II și separat în trei sau, uneori. patru sub-niveluri: IIa1 = sfârşitul fazei Vinča A2începutul fazei A3, IIa2 = faza A3, IIb = faza A3-B1 ${ }^{82}$; sau nivelul II este divizat în sub-nivelul IIa, împărțit în IIa1 și IIa2 ${ }^{83}$; sau nivelul vinčian este separat în patru sub-niveluri: IIa1 = sfârșitul fazei Vinča A2-începutul fazei A3, IIa2 = faza A3, IIb = faza A3-B1 și II/III = faza B1 cu ceramică pictată de tip Lumea Nouă ${ }^{84}$. Imaginea generală oferită a fost că avem de-a face cu un nivel habitaţional ce se corelează, în cea mai mare măsură, prin numărul de complexe integrate în cele patru mari etape definite, cu sub-fazele Vinča A2 și A3.

Conform opiniei din 2009 a lui C. Suciu, complexele arheologice B4b, B18, B12 sunt caracteristice pentru subnivelul IIa1, complexele B5, B7, B15 pentru sub-nivelul IIa2, iar locuințele de suprafață L3, L11, L13, L14 sunt reprezentative pentru sub-nivelul $\mathrm{IIb}^{85}$; sub-nivelului II/III i-au fost atribuite complexele G41 și G44 ${ }^{86}$. Complexul arheologic B2, neabordat/nepublicat de C. Suciu, a fost încadrat mai recent în sub-nivelul IIa2 ${ }^{87}$. Sub-nivelele discutate mai sus au fost considerate, în cea mai consistentă lucrare referitoare la nivelul Vinča de la Miercurea Sibiului, ca fiind contemporane, corespunzător, cu etapele Vinča A2, A3, B1a și B1b conform cronologiei propusă de W. Schier ${ }^{88}$, neschimbând impresia generală, de contemporaneitate, în special cu faza A a culturii Vinča.

Tabelele de contingență publicate, care conțin fiecare câte un singur tip de variabilă morfologică a ceramicii culturii Vinča (i.e. tip de parte superioară vas/buză, tip parte inferioară vas/fund, tip de toartă/buton, tip de ornament) din situl de la Miercurea Sibiului-Petriș ${ }^{89}$ prezintă o imagine greu de interpretat, a căror rezultate dorite cu valoare cronologică sunt neclare și neconvingătoare comparativ cu schema cronologică clară deja prezentată, de C. Suciu

\footnotetext{
${ }^{80}$ Suciu 2009.

${ }^{81}$ Nițu 2012a.

${ }^{82}$ Luca et al. 2006, 13 (text în limba română); această sub-împărțire nu este în conformitate cu aceeași sursă, p. 10 (text în limba engleză), unde nivelul II este văzut ca fiind format din sub-nivelul IIa, divizat în IIa1 şi IIa2 [sic!]. Luca, Diaconescu, Suciu 2008, 28, unde nivelul IIa este paralelizat cu etapele Vinča A2-A3.

${ }^{83}$ Luca et al. 2007, 12 (text în limba engleză); nu este în conformitate cu aceeași sursă p. 8 (text în limba română) unde nivelul II este separat în trei sub-niveluri: IIa1 - sfârşitul fazei A2-începutul fazeiA3, IIa2 - faza A3, IIb - sfârşitul fazei A3-începutul fazei B1 [sic!].

${ }^{84}$ Luca, Diaconescu, Suciu 2008, 326-327; Luca, Diaconescu, Suciu 2011, 23 păstrează aceeași opinie. Interesant este faptul că în Luca 2016, 239 nivelul vinčian este, din nou, împărțit în doar trei sub-niveluri: IIa1, IIa2, IIb, nemaiexistând nici o referire la nivelul II/III.

${ }^{85}$ Suciu 2009, 89-134.

${ }^{86}$ Luca et al. 2008a, 199. Suciu 2009, 174 face referire la un fragment ceramic pictat de tip Lumea Nouă descoperit în G44/2007, complex pe care autorul îl consideră a fi „mai târziu” și îl atribuie nivelului II/III.

${ }^{87}$ Luca 2016, 240. Totuși la Suciu 2009, 89, fig. 117, bordeiul B2 este încadrat în sub-nivelul IIa1.

${ }^{88}$ Suciu 2009, 42, fig. 28. De remarcat faptul că, și dacă în partea de lucrare ce abordează problematica sitului de la Miercurea Sibiului, nivelul II/III este menționat o singură dată (Suciu 2009, 174), acesta apare însă desemnat foarte clar în figura de la p. 42

${ }^{89}$ Suciu 2009, figs. 343, 346, 348, 350; Nițu 2012a, tab. II.III.5, II.III.6, II.III.7, II.III.8; Nițu 2012b, tab. 5, 6, 8; Niţu 2014, tab. 1 și 3 .
} 




Figura 3. Dispunerea siturilor de la Tărtăria. 1. Gura Luncii; 2. Gura Luncii/Gura Văii Cioarei; 3. Pietroșița.

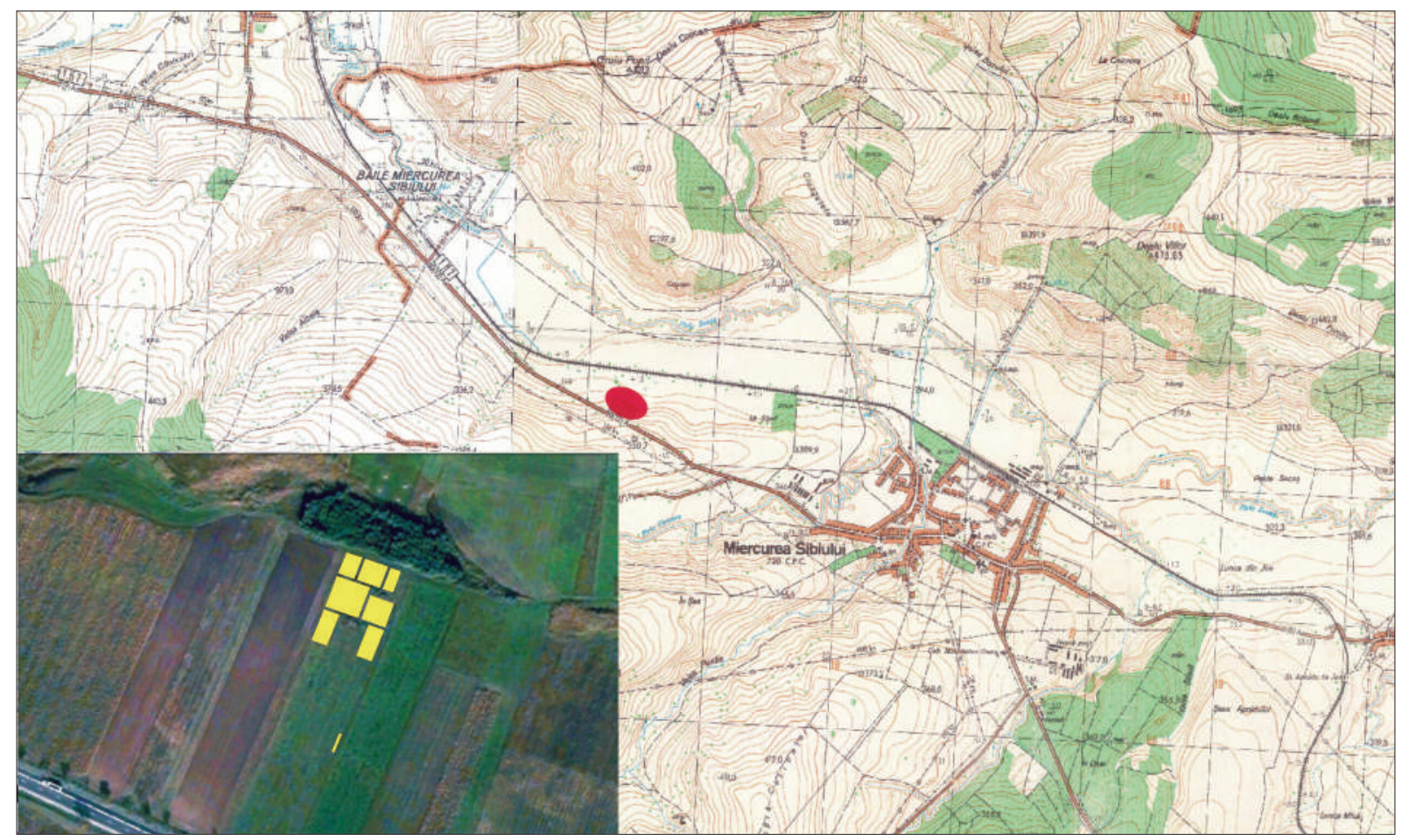

Figura 4. Harta cu poziționarea sitului de la Miercurea Sibiului - Petriș și planul de detaliu cu poziționarea unităților de cercetare din campaniile 2001-2010 (marcate cu galben). 
şi S. A. Luca. Principala dificultate întâmpinată în acest demers, aspect deja subliniat în literatura de specialitate, a fost dată de limitele pachetului de programe Zeus ${ }^{90}$, software folosit și în analizele discutate mai sus.

\subsection{Utilizarea CA pentru descoperirile nivelurilor II și II/III de la Miercurea Sibiului}

În consecință, am considerat oportună folosirea analizei de corespondență $(C A)$ pentru a verifica schema cronologică propusă pentru nivelul habitațional aparținând culturii Vinča de la Miercurea Sibiului. Această metodă a fost aplicată cu succes pe materialele ceramice aparținând unor culturi preistorice din Europa centrală și de sud-est ${ }^{91}$. Programul folosit pentru aplicarea $C A$ este WinBasp 5.4392. Caracteristicile morfologice ale ceramicii vinčiene de la Miercurea Sibiului au fost extrase în mare majoritate din tabelele de contingentă publicate de F. M. Niţu $^{93}$ și, pentru materialele neintegrate în analiza sa de către colega noastră, din planșele publicate de C. Suciu ${ }^{94}$. Pentru complexul G8, care lipsește în analiza F. M. Niţu, au fost folosite datele publicate de C. Suciu ${ }^{95}$, iar pentru complexul B2 ilustrațiile puse în circuitul științific de către S. A. Luca ${ }^{96}$. În acest mod 22 de unități de analiză au fost utilizate în procesul de analiză, reprezentând 22 de complexe arheologice atribuite culturii Vinča, folosind în chip de coduri denominative trei litere: G pentru gropi, B pentru bordeie și L pentru locuințele de suprafață. Codurile pentru aceste complexe sunt conforme cu cele publicate de C. Suciu și F. M. Niţu. Distribuţia spațială a acestor complexe este reprezentată în Fig. 5.

Caracteristicile morfologice ale ceramicii oferă 222 de variabile, fiind create 1251 de incidențe. Rezultatele CA sunt prezentate în Fig. 6a și prezintă o tendinţă de grupare de tip parabolă. Trei grupuri de unități sunt vizibile, primul fiind situat în cadrul graficului în cadranele II și III, al doilea în cadranul IV și al treilea în cadranul I. Primul grup (cadranele II și III, partea stângă a graficului din Fig. 6a) este numit aici IIA1 și este compus din 14 unități (G55, B7, B4B, G80, G73, G44, G57, B8, G41, B2, B22, G8, L3 şi B5). Al doilea cluster, etichetat ca IIA2, cuprinde cinci unități (G30, B18, B15, G23, B12), iar al treilea grup numit IIB, este compus din doar trei complexe (L11, L13, L14). Luând în considerare relațile stratigrafice directe dintre unele din complexele analizate, vizibile în Fig. 5 (e.g. L11 suprapune B5, B18 și G23, L13 suprapune G30 și L3 suprapune G8), dispunerea unităților din Fig. 6a se poate considera ca fiind influențată de factorul temporal, plecând de la primul grup definit aici către cel de-al treilea. Relația stratigrafică și cea din rezultatele $C A$ dintre L3 și G8 necesită câteva mențiuni suplimentare, pe care suntem nevoiți să le menționăm aici. Complexul G8 a fost cercetat în campania 2003, fiind în fapt o groapă de formă ovală. Complexul L3 a fost cercetat în campania 2002 şi prezenta aceleași caracteristici constructive (aglomerări de piatră de râu) cu L13, L14 și L11 (cercetate în campania 2004), fiind în fapt sub-structura podelei unei structuri interpretate ca locuință de suprafață, nearsă. Singura diferență este că, în campania 2004, nivelul de călcare aferent acestor structuri/aglomerări de piatră de râu a fost atent cercetat prin șpăcluire, documentat și recoltat ca atare. Nu dorim să comentăm aici modalitatea de cercetare, documentare și recoltare a materialului atribuit locuinței L3, dar plasarea extrem de apropiată a unităţilor de analiză L3 și G8 în etapa IIA1 din Fig. 6a ne indică faptul că marea majoritate a materialului atribuit L3 face parte de fapt din umplutura complexului G8, indicând o manieră defectuoasă de cercetare de teren.

Marcarea cromatică a unităților de analiză/complexe Vinča corespunzător schemei cronologico-stratigrafice propusă de C. Suciu, astfel încât complexele aparținând sub-nivelului IIal să fie reprezentate cu albastru deschis, cele din sub-nivelul IIa2 cu negru, cele din sub-nivelul IIb cu verde, cele din sub-nivelul II/III cu violet, iar cele neincluse în schema respectivă cu roșu, oferă imaginea prezentată în Fig. 6b. Această imagine subliniază încă o dată limitele programului folosit în analiza ceramicii de către C. Suciu și F. M. Nițu, pentru că distribuţia complexelor din sub-nivelul IIa1 este vizibilă în grupurile IIA1 și IIA2, același lucru putând fi observat și pentru complexele aparţinând sub-nivelului IIa2. Sub-nivelul IIb, are din cele patru complexe arondate, unul (L3) distribuit în clusterul IIA1 (aspect deja explicat mai sus) și pe celelalte trei (L11, L13, L14) situate în clusterul IIB. Foarte important de subliniat este poziționarea celor două complexe atribuite sub-nivelului II/III (G41 și G44) $)^{97}$ în clusterul IIA1, în puternică contradicție cu afirmațiile precedente care considerau acest sub-nivel ca fiind cel mai târziu în cadrul nivelului habitațional vinčian de la Miercurea Sibiului. Ce este interesant este că cele două complexe G41 și G44 (care conține ceramică pictată de tip Lumea Nouă) se află situate în acelaşi grup de unităţi

\footnotetext{
$\overline{{ }^{90} \text { Diaconescu 2014a }}, 220$, n.7; aici e important să reiterăm faptul că tabelele de contingență seriate de cei doi colegi conțineau fiecare doar câte un singur tip de variabilă (e.g. tip de parte superioară vas/buză, tip parte inferioară vas/fund, tip de toartă/ buton, tip de ornament).

${ }^{91}$ De exemplu vezi Schier 1995, Schier 1996, Furholt 2008a, Furholt 2008b, Müller 2009, Diaconescu 2014b, Diaconescu $2014 c$.

${ }^{92} \mathrm{http}: / /$ www.uni-koeln.de/ al001/.

${ }^{93}$ Nițu 2014, Niţu 2012, Niţu 2012b.

${ }^{94}$ Suciu 2009, fig. 121, 122, 128-132, 138-142, 149, 150, 170-172, 178-188, 192-195.

${ }^{95}$ Suciu 2009, fig. 157-161. Complexul G8 este atribuit sub-nivelului IIa2, conform Suciu 2009, 89, fig. 117.

${ }^{96}$ Luca 2016 , 240, pl. I și pl. II/1-2

${ }^{97}$ Luca et al. 2008a, 199.
} 
de analiză ca și complexul B4b, complex integrat de C. Suciu în sub-nivelul IIa1, dar care conține de asemenea ceramică pictată de tip Lumea Nouă (Zau), aspect subliniat relativ recent ${ }^{98}$.

\subsection{Verificarea valorii cronologice absolute a rezultatelor $\boldsymbol{C A}$}

Pe lângă relațiile stratigrafice directe dintre unele complexe vinčiene de la Miercurea Sibiului, pentru o evaluare din perspectivă cronologică a rezultatelor $C A$, cinci date ${ }^{14} \mathrm{C}$ sunt prezente în literatura de specialitate ${ }^{99}$.

Tabelul 1. Datele ${ }^{14} \mathrm{C}$ atribuite complexelor Vinča de la Miercurea Sibiului (după Biagi 2015, 245).

\begin{tabular}{|cccccc|}
\hline Nr. Lab. & $\begin{array}{c}\text { Valoare } \\
\text { BP }\end{array}$ & calBC 2 $\sigma$ & Material & Complex & Sub-nivel/cluster \\
\hline GrA-43076 & $6160 \pm 50$ & $5260-4940$ & $\begin{array}{c}\text { Reziduu organic de } \\
\text { pe interiorul unui } \\
\text { fragment ceramic }\end{array}$ & $\begin{array}{c}\text { B18 (pit 18 } \\
\text { Biagi) }\end{array}$ & IIa1 (Suciu 2009); IIA2 aici \\
\hline GrA-26606 & $6180 \pm 40$ & $5280-4990$ & mandibulă Bos & B9 (pit 9 Biagi) & $\begin{array}{c}\text { Ic=Starčevo-Criş faza III } \\
\text { (Luca et al. 2006) }\end{array}$ \\
\hline GrN-30500 & $6200 \pm 60$ & $5310-4990$ & astragal Cervus & L3 (pit 3 Biagi) & IIb (Suciu 2009); IIA1 aici \\
\hline GrN-29053 & $6350 \pm 130$ & $5650-4950$ & calcaneum Bos & $\begin{array}{c}\text { L11 (pit 11 } \\
\text { Biagi) }\end{array}$ & IIb (Suciu 2009); IIB aici \\
\hline GrA-33127 & $6475 \pm 40$ & $5490-5320$ & Triticum dicoccum & $\begin{array}{c}\text { B18 (pit 18 } \\
\text { Biagi) }\end{array}$ & IIa1 (Suciu 2009); IIA2 aici \\
\hline
\end{tabular}

Doar patru dintre aceste date (GrA-43076, GrA-33127, GrN-29053, GrN 30500) au fost folosite de curând pentru o estimare a etapei cronologice a nivelului II din situl de la Miercurea Sibiului, cea de-a cincea (GrA-26606) fiind neutilizată din cauza caracterului său intruziv, proba provenind dintr-un context Starčevo - Criș ${ }^{100}$. Rezultatele obținute, încadrează nivelul ocupațional Vinča, atribuit fazei B, între 5290-5095 cal BC (Start) și 5170-4970 cal $\mathrm{BC}($ End $)(68 \% \text { probabilitate })^{101}$.

Tabelul 2. Date ${ }^{14} \mathrm{C}$ inedite din nivelul habitațional Vinča de la Miercurea Sibiului - Petriș

\begin{tabular}{|lcclll|}
\hline Lab. No. & $\begin{array}{c}\text { Valoare } \\
\text { BP }\end{array}$ & calBC 2 $\sigma$ & \multicolumn{1}{c|}{ Material } & Complex & \multicolumn{1}{c|}{ Cluster } \\
\hline Poz-61037 & $6060 \pm 40$ & $5061-4842$ & Corn de Bos & B12 & IIA2 aici \\
\hline Poz-61038 & $6070 \pm 40$ & $5071-4844$ & metacarp Bos & G55 & IIA1 aici \\
\hline Poz-61039 & $6190 \pm 40$ & $5231-5026$ & Corn de Bos & G44 & IIA1 aici \\
\hline Poz-61040 & $6110 \pm 40$ & $5208-4942$ & metacarp Bos & G81 & Nedeterminat \\
\hline Poz-61041 & $6000 \pm 70$ & $5061-4718$ & metacarp Bos & G83 & Nedeterminat \\
\hline Poz-61045 & $6180 \pm 40$ & $5229-5002$ & Craniu uman & G73 & IIA1 aici \\
\hline Poz-61046 & $6090 \pm 40$ & $5082-4900$ & Corn de Bos & B22 & IIA1 aici \\
\hline
\end{tabular}

* $\mathrm{Nu}$ au fost efectuate analize speciale de determinare a izotopilor $\delta^{13} \mathrm{C} s ̦ i \delta^{15} \mathrm{~N}$, analize care să ofere date legate de paleo-dieta individului respectiv și de o eventuală influență de tip freshwater reservoir effect.

În 2013, prin suportul financiar oferit de un proiect condus de C. Suciu, șapte probe din tot atâtea complexe aparținând culturii Vinča de la Miercurea Sibiului - Petriș, au fost prelevate și trimise la laboratorul din Poznan.

\footnotetext{
${ }^{98}$ Luca 2016, 243, photo 254 face atribuirea respectivă doar în cadrul textului explicativ al figurii. Fragmentele ceramice pictate sunt publicate și de Suciu 2009, 93, fig. 123/f care discută aceste fragmente din B4b în cadrul relațiilor lumii vinčiene cu orizontul Esztár - Pişcolt - Raškovce - Sátoraljaújhely - Lumea Nouă/Zau (vezi Suciu 2009, 174), dar cărora le vede cele mai bune analogii în mediul Dimini timpuriu, omițând însă o analogie extrem de bună pentru asocierea dintre forma de vas (strachină lobată) și motivul pictural exterior (bandă lată verticală pictată brun-vișiniu pe fond alb-gălbui) oferită chiar de descoperirile din situl de la Alba Iulia - Lumea Nouă (vezi Berciu, Berciu 1949, 11, fig. 7 sau Gligor 2009, pl. CLXIV) şi integrată de descoperitori în tipul ceramic D1a.

${ }^{99}$ Biagi 2015, 245, Table 1.

${ }^{100}$ Whittle et al. 2016, 15, n. 8 .

${ }^{101}$ Whittle et al 2016, 15.
} 


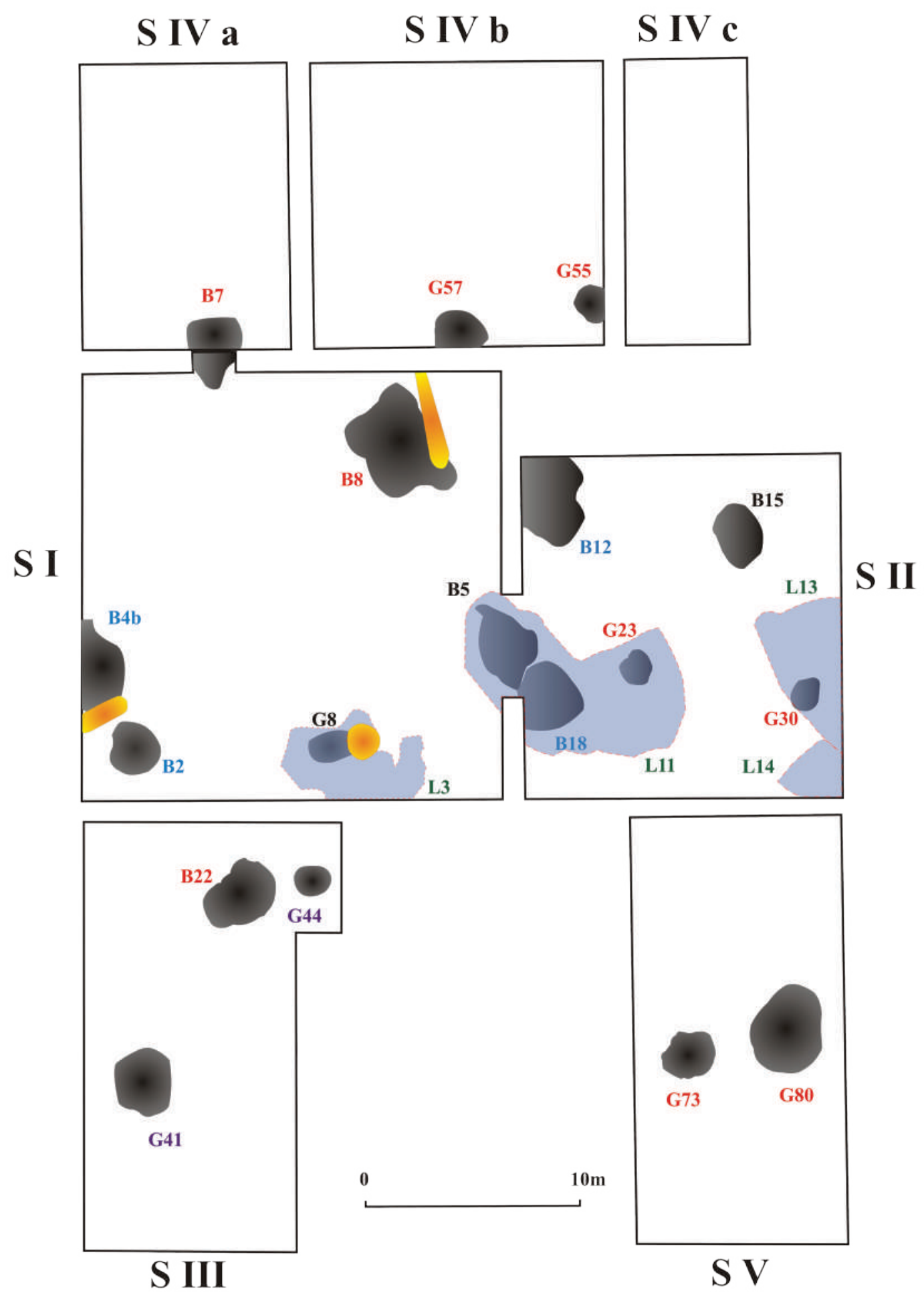

Figura 5. Distribuția spațială a complexelor aparținând culturii Vinča analizate prin CA. Cu albastru deschis sunt desemnate complexele atribuite nivelului IIa1, cu negru cele integrate în nivelul IIa2, cu verde cele aparținând nivelului $\mathrm{IIb}$, cu violet cele atribuite nivelului II/III. Cu roșu sunt marcate complexele neincluse în nici unul din sub-nivelurile sitului de la Miercurea Sibiului . 
La acel moment nevoia de date de cronologie absolută era stringentă pentru a putea verifica aspectul temporal al rezultatelor demersurilor întreprinse de F. M. Nițu ${ }^{102}$. Datele respective sunt prezentate în Tabelul 2 (toate datele din acest studiu sunt calibrate folosind curba de calibrare IntCal $13^{103}$ ). Astfel au fost selectate probe din complexe situate în unitățile de cercetare S.II (B12), S.III (G41, B22), S.IV b (G55) și S.V (G73, G81, G83) într-o încercare de a "acoperi teritorial" cât mai bine, din perspectiva cronologiei absolute, arealul cercetat. Cu excepția complexului B12 pe care îl regăsim și în analiza întreprinsă de C. Suciu, toate celelalte șase complexe erau inedite și incluse în analiza F. M. Niţu, subliniind practic dorința de a susține cu date de cronologie absolută demersurile respective. Din păcate, din motive mai presus de noi, complexele G83 și G81 nu au mai apucat să fie evaluate de regretata noastră colegă.

Folosind ca prior-estimates rezultatele analizei de corespondență, a fost construit un model bayesian ${ }^{104}$, în care, au fost utilizate datele GrA-43076, GrA-33127, GrN 30500 și Poz-61037, Poz-61038, Poz-61039, Poz-61045, Poz-61046. Data GrN-29053 a fost exclusă datorită deviației standard mult prea mare ( \pm 130$)$, iar datele Poz-61040 și Poz-61041 nu au fost utilizate în abordarea bayesiană din imposibilitatea integrării complexelor din care provin (G81 și respectiv G83), cu excepția valorii numerice a datelor, în cadrul etapelor definite prin rezultatele $C A$.

Folosind ca exemplu inspirațional structura modelului bayesian creat de A. Whittle și colaboratorii săi ${ }^{105}$ au fost definite fazele $G 73, G 44, B 22$, $G 55$ L3 (i.e. clusterul IIA1) și B18, B12 (i.e. clusterul IIA2).

Modelul, prezentat în Fig. 7 prezintă un agreement de 67,3\%, subliniind valoarea și cronologică a rezultatelor $C A$ și sugerează că etapele Vinča IIA1 și IIA2 de la Miercurea Sibiului-Petriş apar între 5300-5025 cal BC (95,4\% probabilitate; Start Miercurea) sau 5168-5056 cal BC (68\% probabilitate; Start Miercurea) și 5065-4820 cal BC (95\% probabilitate; End Miercurea) sau 5036-4934 cal BC (68\% probabilitate; End Miercurea). Valorile mean pentru limitele Start și End al modelului cronologic din Fig. 7 indică un interval cronologic cuprins între cca 5149$4971 \mathrm{cal} \mathrm{BC}$.

Elaborarea sumelor mărginite pentru fiecare din cele două faze (IIA1 și IIA2) din modelul prezentat în Fig. 7 și compararea intervalului $\sigma$ a fiecăreia dintre ele (ca zona cea mai consistentă a fiecărui grup de date) cu o diagramă cronologică deja binecunoscută, elaborată pe baza sistemului cronologic a lui V. Milojcić, pentru cultura Vinča ${ }^{106}$, devine extrem de clar că etapa IIA1 are intervalul $\sigma$ cuprins între cca 5130-5025 cal BC și este contemporană cu zona cea mai consistentă a fazei Vinča B1, iar etapa IIA2 oferă un interval $\sigma$ cuprins între cca 5060-4975 cal BC în bună corelație cu Vinča B2 (vezi Fig. 8).

Ce înseamnă aceste rezultate din perspectiva stilistică a modei ceramice? Dacă facem o comparație, pe baza Fig. 6b, între sistemul cronologico-stilistic propus de C. Suciu și rezultatele prezentei abordări se poate observa că etapa IIA1 este compusă din complexe aparținând sub-nivelurilor IIa1, IIa2, IIb și II/III, etapa IIA2 cuprinde complexe din subnivelurile IIa1 și IIa2, etapa IIB fiind singura care include, aproximativ aceleași complexe ca sub-nivelul IIb. Dacă acceptăm că sub-nivelurile IIa1 și IIa2 de la Miercurea sunt contemporane cu Vinča A2 și A3 ${ }^{107}$ este oare etapa cea mai timpurie nou definită IIA1 contemporană cu faza Vinča A? În Fig. 8 se poate vedea că zona cea mai aplatizată, din stânga, a digramei sumei mărginite pentru etapa IIA1 suprapune foarte scurt partea finală a zonei cele mai consistente a intervalului cronologic definit pentru faza Vinča A, între cca 5225-5175 cal BC.

\section{Comparația cu situl eponim al culturii Vinča}

Cea mai bună metodă de a rezolva această chestiune este comparația directă, prin folosirea analizei de corespondență, dintre complexele de la Miercurea Sibiului cu cele din situl de la Vinča - Belo Brdo. Pornind de la cataloagele tipologice create de Florina Maria Nițu ${ }^{108}$ și completându-le, atunci când a fost cazul, în conformitate cu sistemul creat de colega noastră (vezi cataloagele tipologice de la Fig. 14-19), materialele ceramice de la Belo Brdo, dintre

\footnotetext{
102 Din păcate o boală nemiloasă a împiedicat-o pe colega noastră să mai poată folosi rezultatele primite în aprilie 2014 de la Poznan, răpind-o dintre noi, la o vârstă mult prea tânără, în luna august 2014.

${ }^{103}$ Reimer et al. 2013.

${ }^{104}$ Bronk Ramsey 2009.

${ }^{105}$ Whittle et al. 2016, 15-16, fig. 11; vezi de asemenea explicațiile pentru fig. 7.

${ }^{106}$ Whittle et al. 2016, 40, fig. 37.

${ }^{107}$ Suciu 2009, 42, fig. 28.

108 Nițu 2008; Nițu 2012a. Diferitele variante de ornamente au fost codate plecând de la catalogele de ornamente create de colega noastră, în funcție de tehnica de decorare, după cum urmează: OA-pliseuri, OB-canelură, OC-incizie, OD-tăieturi şi crestături, OE-alveolare, OF-impresiuni, OG-împunsături, OH-imprimare, OJ-perforație, OK-barbotină, OL-aplicare și alveolare, OM-impresiune, crestături, alveolare pe buza vasului, OP-bandă punctat-incizată, OR-spatulare și/sau lustruire (vezi Nițu 2012a, 85-103). Noi am mai adăugat tipul de ornament OS-pictare.
} 
adâncimile de 9,3 m până la 6,5 m ${ }^{109}$, au fost introduse în aceeași bază de date cu cele de la Miercurea SibiuluiPetriș. Conform opiniei lui W. Schier, ceramica cuprinsă între adâncimile menționate mai sus este reprezentativă pentru etapele A și B ale culturii Vinča, corespunzând fazelor 2a, 2b, 3, 4, 5a, 5b și 5c din analiza autorului german $^{110}$. Cincizeci și trei de unități de analiză caracterizate de patru sute douăzeci de variabile sunt cuprinse în analiza respectivă, rezultatele $C A$ fiind prezentate în Fig. 9.

Este clar că grupurile/etapele definite de la Miercurea Sibiului sunt vizibile, dar este extrem de evidentă și disocierea față de materialele de la Belo-Brdo, oferind o perspectivă uşor neașteptată. În dispunerea unităţilor de analiză de la Vinča sunt vizibile de asemenea trei grupuri: primul este situat în cadranul IV al graficului din Fig. 9 și este compus din G. 9.3, G.T, G.A, G.R, G.9.2, G.M, G.K, G.W, G.B, 9.3, 9.0, 9.2. 9.1 ${ }^{111}$, al doilea grup, dispus în partea dreaptă a cadranului I, este format din unitățile $8.9,8.7,8.5,8.4,8.3,8.1,8.0$, iar cel de-al treilea grup, plasat în partea stângă a cadranului I, cuprinde unitățile 7.8, 7.7, 7.3, 7.6, 7.5, 7.0, 6.9, 6.7, 6.6, 6.5. Primul grup este compus din unități ce corespund fazelor $2 \mathrm{a}, 2 \mathrm{~b}$ și parțial $3^{112}$, al doilea grup este format din unități integrate în fazele parțial 3 şi $4^{113}$, iar cel de-al treilea corespunde fazelor 5a, 5b, 5c ${ }^{114}$.

Această disociere dintre descoperirile de la Miercurea Sibiului și Vinča face necesară verificarea prezenței și a unei eventuale valori cronologice a unităților de la Vinča în cadrul $C A$. Astfel, crearea unei baze de date doar pentru unitățile de analiză de la Belo Brdo ne oferă imaginea din Fig. 10.

Influența factorului cronologic este extrem de vizibilă, având în vedere dispunerea, dinspre colțul dreapta sus al graficului către colțul stânga sus, a nivelurilor/gropilor înregistrate altimetric. Rezultatele obținute de noi sunt într-o foarte bună corelație cu cele obținute de W. Schier în cadrul aceluiaşi $\operatorname{sit}^{115}$.

Practic, rezultatele de mai sus ne conduc către o concluzie cu caracter preliminar în cadrul excursului nostru. Mai precis ceramica atribuită culturii Vinča de la Miercurea Sibiului este contemporană cu faza B a culturii, dar diferită din punct de vedere stilistic de ceramica fazelor 5a, $5 \mathrm{~b}$ și $5 \mathrm{c}$ de la Belo Brdo, etape reprezentative pentru faza B a culturii Vinča. De asemenea putem sublinia că nu există elemente de tip Vinča A (așa cum au fost definite în situl eponim) pe care să le regăsim la Miercurea Sibiului, acest aspect, pe lângă valorile cronologice absolute ale etapelor definite în situl de la Petriș, accentuând absența primei faze a culturii Vinča în cadrul descoperirilor din respectivul nivel habitaţional.

\subsection{Includerea altor situri în discuție}

Dintre siturile atribuite culturii Vinča din Transilvania, pe lângă situl de la Miercurea Sibiului discutat în detaliu mai sus, singurele materiale care oferă suficiente elemente pretabile pentru analiza de corespondență sunt, așa cum am precizat deja, cele publicate relativ de curând, de la Tărtăria - Gura Luncii/Gura Văii Cioarei ${ }^{116}$ (complexul C.5/2014) şi Tărtăria - Pietroșița ${ }^{117}$ (complexul C.53 din acest sit a fost selectat pentru analiza de corespondență,

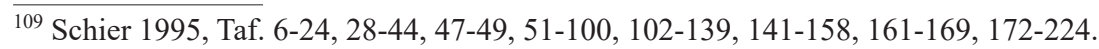

${ }_{110}$ Schier 1996, 158, fig. 9.

${ }^{111} \mathrm{Cu}$ litera $\mathrm{G}$ sunt indicate gropile din situl de la Vinča.

112 Schier 1996, 152, Fig. 2., i.e. Vinča A1 și parțial A2.

${ }^{113}$ Schier 1996, 152, Fig. 2, i.e. parţialVinča A2 şi A3.

${ }^{114}$ Schier 1996, 152, Fig. 2, i.e. Vinča B1 și B2.

${ }^{115}$ Schier 1995, 207, Abb. 114; Schier 1996, 152, fig. 2; Schier 2000, 192, fig. 4.

${ }^{116}$ Rogozea 2016, 121-161, fig. VI/4-6; VII-XI; autorul încadrează materialele Vinča de aici, din complexul C.5/2014 în faza A3. Pentru localizarea acestui sit vezi Fig. 3 de mai sus. Chiar dacă autorul consideră că situl de la Balomiru de CâmpGura Văii Cioarei este cel mai apropiat de situl pe care îl discută (vezi Rogozea 2016, 121-122) totuși, centrul sitului de la Tărtăria - Gura Luncii este situat la 421 m, pe direcție ENE de situl în cauză, iar situl de la Balomiru de CâmpGura Văii Cioarei, pe coordonatele indicate de O. Rogozea (4556'37.17" N, 2323'32.57" E - Rogozea 2016, 123) se află la 1279 m pe direcție VSV de situl respectiv. Coordonatele GPS oferite de C. Suciu pentru așezarea de la Balomiru de Câmp sunt de fapt datele sitului din care O. Rogozea publică în 2016 materialele considerate Vinča A3 (verificarea acestor date s-a putut face utilizând harta militară a României de la https://portal.geomil.ro/arcgis/home/webmap/viewer. html?webmap=cce134f4a9694d9faa353983fbc15635 - accesat în data de 10.02.2020). Conform Lazarovici, Kalmar-Maxim 1991a, 95-96, situl de la Gura Văii Cioarei este situat la stânga Văii Cioarei pe o terasă a Mureșului, la 500-600 m vest de situl de la Tărtăria (aceeași opinie privind distanța dintre cele două situri la Vlassa 1967, 404). Folosind coordonatele GPS oferite de O. Rogozea putem vedea că amplasamentul propus se află situat la stânga Văii Cioarei, în imediata vecinătate a confluenței pârâului Cioara cu Mureșul. Distanța dintre acest amplasament si poziția sitului de la Tărtăria este de 1676 m, pe direcție ENE, de trei ori mai mult decât fusese declarat de descoperitorul sitului, N. Vlassa. O distanță aproximativ egală cu observațiile noastre, de "1,5-2 km în aval" între siturile de la Gura Luncii și cel de la Gura Văii Cioarei este indicată clar de Lazarovici, Maxim 1991, 5. Poziția amplasamentului propus de O. Rogozea este confirmat de rezultatele cercetărilor efectuate de C. I. Popa în zona văii Cugirului (Popa 2011, 672-673). Rogozea 2016, 124 folosește denominativul de Tărtăria - Gura Luncii - Gura Văii Cioarei pentru acest sit, fapt care ne determină să îi respectăm opinia.

${ }^{117}$ Rogozea 2017, pl. 7, 8, 9/1-3.
} 


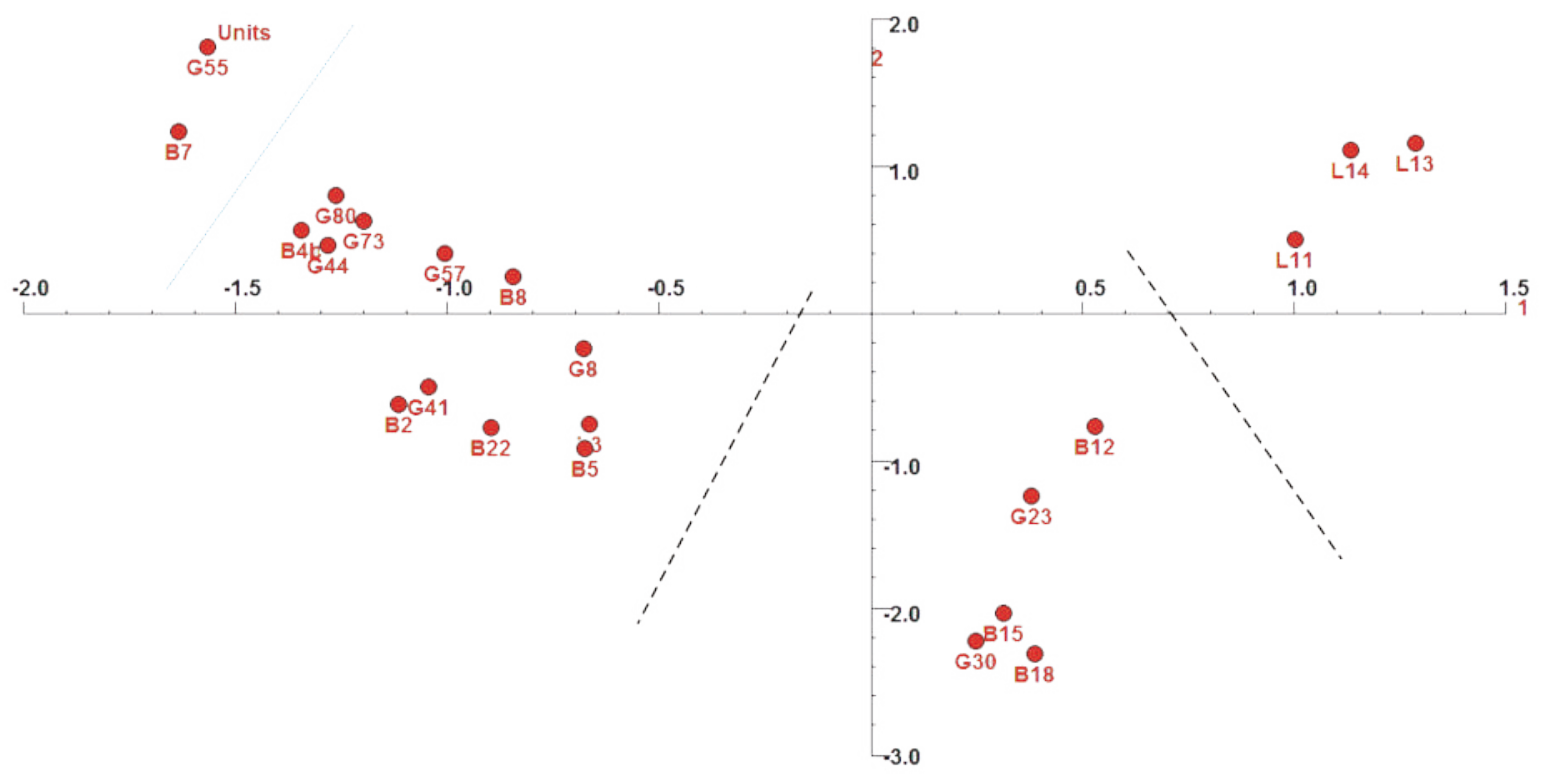

Figura 6a. Rezultatele CA aplicată pe complexele aparținând culturii Vinča de la Miercurea Sibiului folosind informațiile preluate din literatura de specialitate menționată.

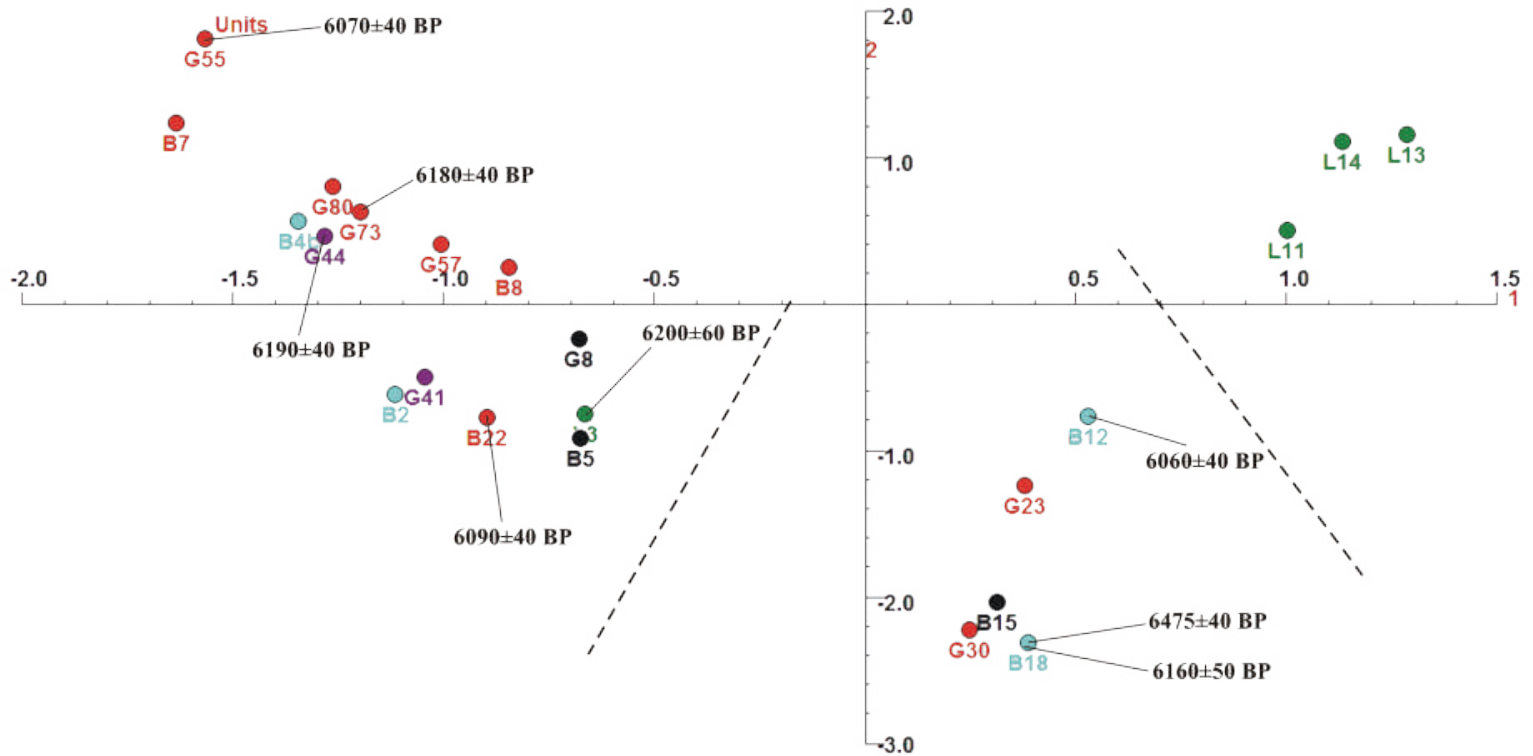

Figura 6b. Rezultatele CA pentru complexele din nivelul II de la Miercurea Sibiului, prezentând și valoarea BP a datelor ${ }^{14} \mathrm{C}$ existente. 


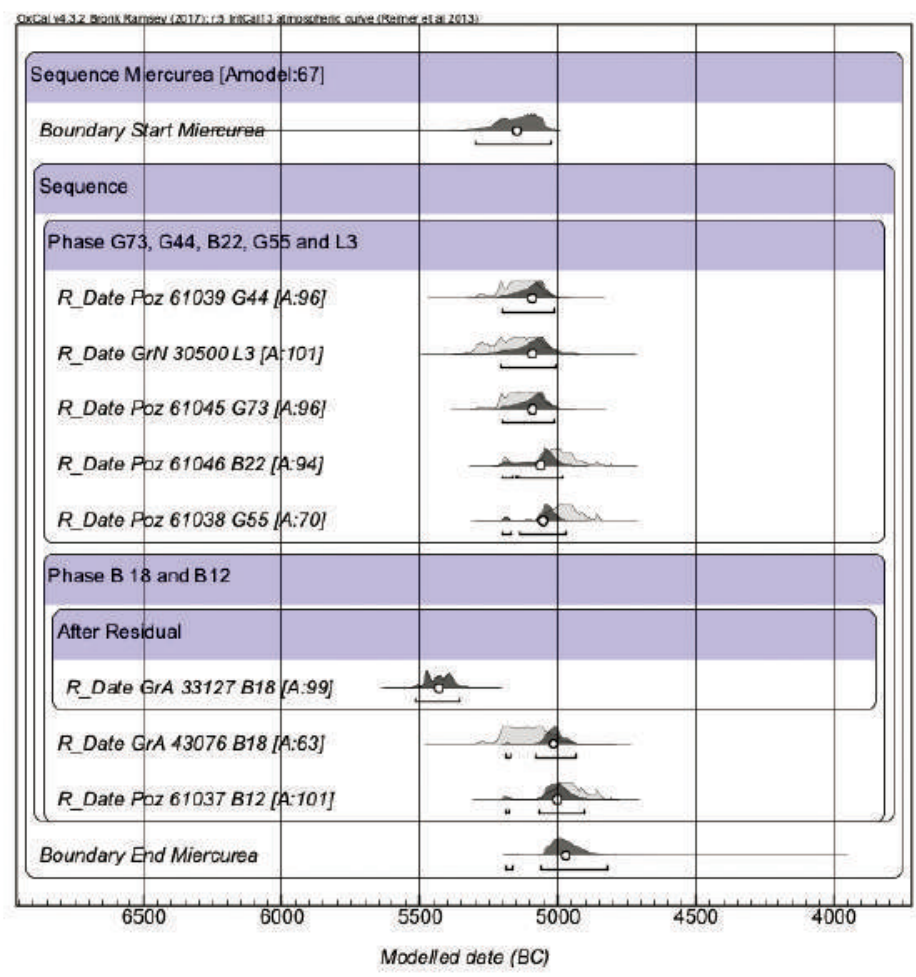

Figura 7. Modelul Bayesian pentru nivelul II din situl de la Miercurea Sibiului, folosind ca și prior-estimates rezultatele CA.

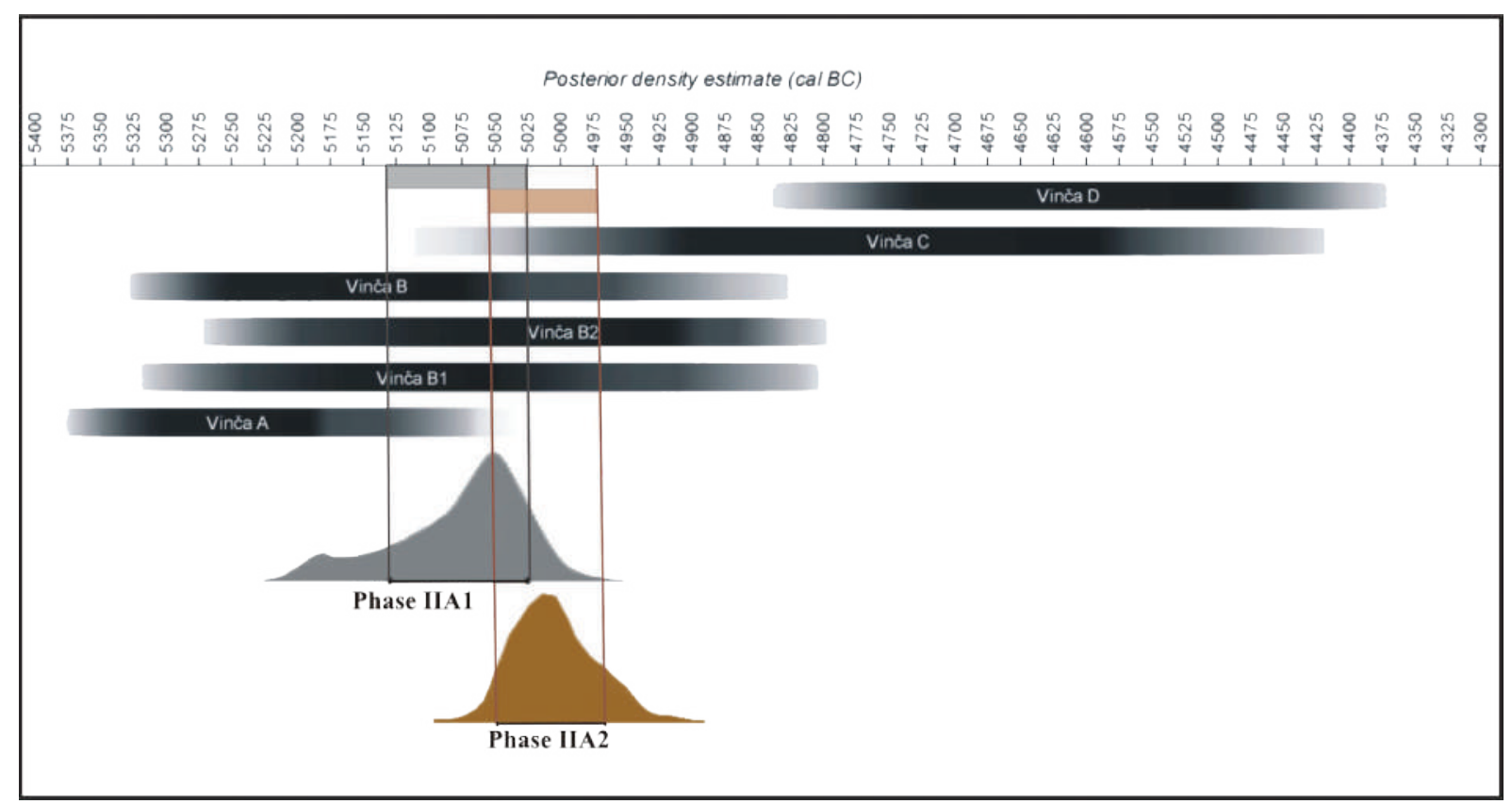

Figura 8. Diagrama cronologică absolută a culturii Vinča și poziția intervalelor $\sigma$ pentru sumele mărginite ale etapelor IIA1 și IIA2 de la Miercurea Sibiului (prelucrare după Whittle et al 2016, fig. 37). 
oferind cel mai consistent lot de ceramică publicat). Dacă analizăm imaginea oferită de harta acestor situri de la Tărtăria (vezi mai sus Fig. 3) putem avansa opinia conform căreia aceste două obiective mai nou definite și cercetate preventiv fac parte de fapt din același ansamblu ca și mai celebrul lor companion, Tărtăria - Gura Luncii.

Din nefericire situri precum Romos-Fagădau ${ }^{118}$, Balomiru de Câmp - Gura Văii Cioarei ${ }^{119}$ sau Limba-Bordane, Limba-Vărărie, Limba - Șesul Orzii ${ }^{120}$ nu oferă la acest moment contexte stratigrafice clare/cu caracter închis pentru materialul publicat. Absența publicării adecvate a contextelor Vinča timpurii din siturile importante de la Tărtăria - Gura Luncii sau Alba Iulia - Lumea Nouă nu sprijină deloc demersurile științifice legate de poziționarea elementelor vinčiene transilvănene în cadrul cronologico-cultural al culturii Vinča. Pentru situl de la Alba IuliaLumea Nouă a fost însă, grație amabilităţii colegului nostru Mihai Gligor, analizat în mod direct complexul C.013/2014-2015 $5^{121}$.

Cele trei complexe numite au fost introduse în baza de date comună a siturilor de la Vinča-Belo Brdo și Miercurea Sibiului-Petriş (vezi Fig. 11). Rezultatele $C A$ oferă imaginea a două grupuri de unități de analiză, cel din cadranele II și III fiind legat de clusterul format de complexele de la Miercurea Sibiului, unde în grupul corespunzător etapei IIA1 putem vedea plasat complexul C013LN (Alba Iulia - Lumea Nonă, C.013/2014-2015, marcat cu culoarea violet). Al doilea grup, situat în cadranele I și II, este format în marea majoritate din unitățile de analiză oferite de situl de la Vinča, dar trebuie sublinată prezența aici a unităților de analiză C5/TartB (C.5/2014 Tărtăria - Gura Luncii/Gura Văii Cioarei) și C53/Tart (C.53/2014 Tărtăria-Pietroșița), complexe provenite din situri transilvănene (marcate cu roșu).

Poziționarea complexului $C 013 L N$ de la Alba Iulia - Lumea Nouă, în acelaşi cluster cu complexele de la Miercurea Sibiului din etapa IIA1, unde se află situate și complexele $B 4 b, G 44$, toate trei conținând ceramică pictată de tip Lumea Nouă, subliniază convergența puternică dintre ele. Complexele G44 și C.013/2014-2015 sunt datate cu ${ }^{14} \mathrm{C}$, dar pentru unitatea stratigrafică de la Alba Iulia doar valoarea calibrată a datei obținute, fără nici un grad de probabilitate specificat, ne este cunoscută: $5178-5066$ cal BC ${ }^{122}$. Totuși această valoarea calibrată corespunde intervalului propus şi definit pentru sub-faza Vinča B1 ${ }^{123}$ și de altfel și pentru etapa IIA1 de la Miercurea Sibiului (vezi mai sus Fig. 8). Astfel, este clar că ceramica de tip Lumea Nouă apare, în două situri arheologice importante pentru neoliticul mijlociu transilvănean, în etapa cronologică absolută corespunzătoarea sub-fazei Vinča B1.

Disparitatea dintre clusterul format din unitățile de analiză de la Miercurea Sibiului și Alba Iulia față de cel format din unitățile de analiză de la Vinča și cele două complexe de la Tărtăria atribuite fazei A3, precum și rezultate foarte recente ${ }^{124}$ creează o bază foarte solidă de redeschidere a discuției legată de existența unei variante transilvănene a culturii Vinča ${ }^{125}$.

Practic rezultatele din Fig. 12 ne indică faptul că, despre existența unui aspect regional transilvănean pentru cultura Vinča, se poate vorbi doar la nivelul cronologic corespunzător fazei B a culturii, când diferențele dintre stilul ceramic al complexelor din Transilvania (e.g. Miercurea Sibiului, Alba Iulia) față de cele de la Vinča-Belo Brdo (adâncimi 7,8-6,5 m) sunt clare.

\section{Problema culturii Vinča, faza A în Transilvania}

Prezența unităților de analiză $C 5 / \operatorname{Tart} B$ și $C 53 /$ Tart în clusterul determinat de unitățile stratigrafice din situl de la Vinča-Belo Brdo (vezi Fig. 12) ridică problema disparității evidente a acestor complexe arheologice față de cele din celelalte două situri transilvănene discutate aici. Acest fenomen poate fi legat, cel mai probabil de factorul temporal, aducând în discuție prezența elementelor de fază Vinča A în Transilvania. Cele două complexe provin din două situri care "flanchează” situl de la Tărtăria - Gura Luncii (vezi Fig. 3, siturile 2 și 3), unul dintre ele, Tărtăria - Pietroșița/Situl $10 b$ fiind amplasat pe aceeași terasă ca cel de la Gura Luncii, conform hărții militare a RSR din 1975.

\footnotetext{
${ }^{118}$ Luca 1995-1996, Taf. I-VI.

${ }^{119}$ Popa 2011, pl. 11-16.

${ }^{120}$ Florescu 2007, fig. 13-26.

${ }^{121}$ Acest complex este încadrat în faza B1 a culturii Vinča și conține fragmente ceramice pictate de tip Lumea Nouă (cf. Ileș 2018, 152 și Mihai Gligor, comunicare personală).

${ }^{122}$ Ileș 2018, 152.

${ }^{123}$ Whittle et al 2016, 40, fig. 37.

${ }^{124}$ Diaconescu, Niţu, Suciu in press

${ }^{125}$ Paul 1965, 298; Garašanin 1979, 192-193; Chapman 1981, 22, 29-30; Garašanin 1982, 125; Garašanin 1993, 15, n. 38; Maxim 1999, 63-64.
} 


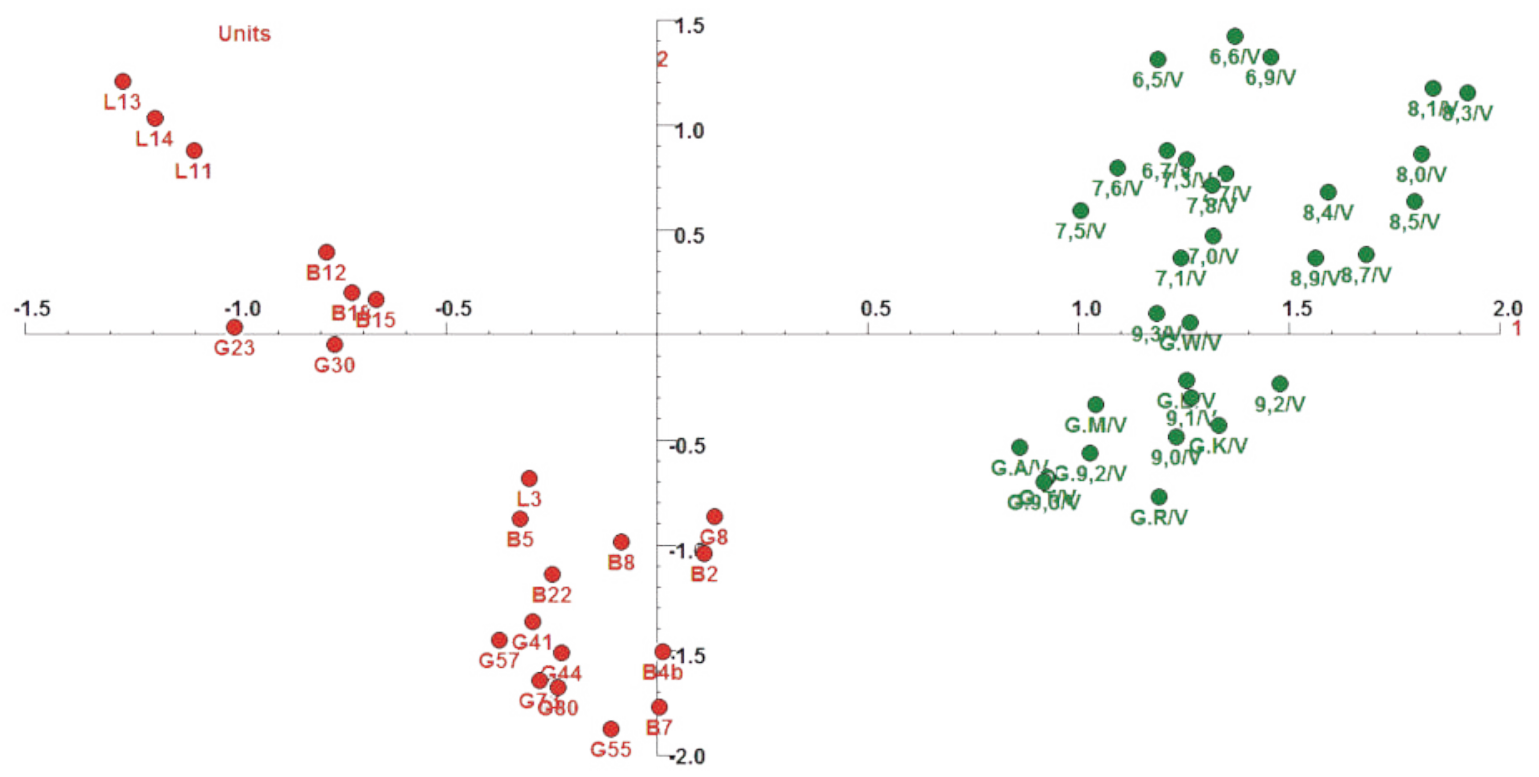

Figura 9. Rezultatele CA aplicată pe complexe/unităţi stratigrafice de la Miercurea Sibiului - Petriş și Vinča - Belo Brdo (ad. 9,3-6,5 m).

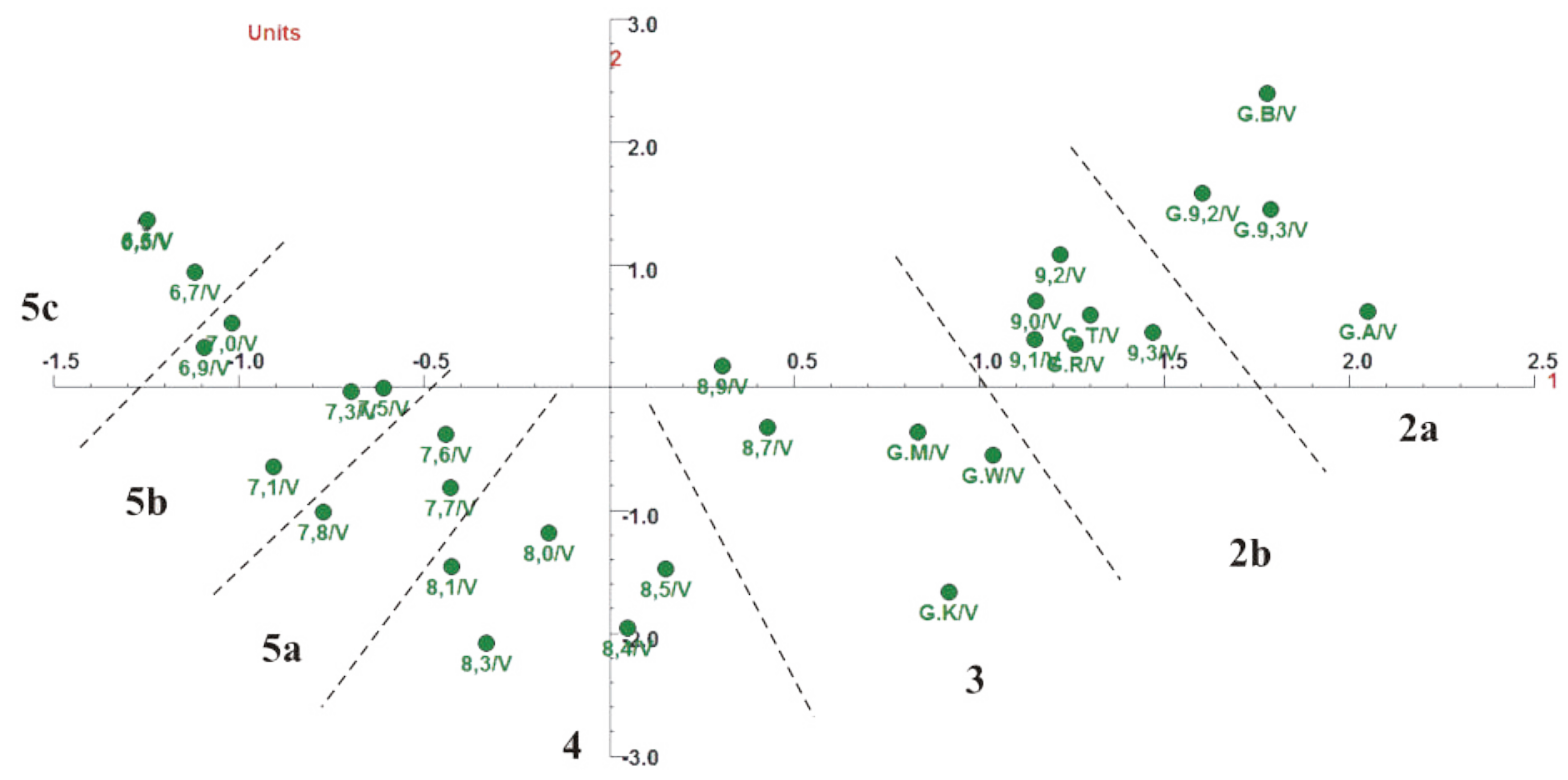

Units: 31 Iypes: $274 \quad$ Incis: 1217

Figura 10. Rezultatele CA aplicată pe unitățile stratigrafice aparținând fazelor timpurii (A și B) ale culturii Vinča din situl eponim de la Belo Brdo. 
Situl de la Tărtăria - Gura Luncii a fost ținta mai multor proiecte de cercetare arheologică de-a lungul timpului, conduse de K. Horedt în 1942-1943 ${ }^{126}$, N. Vlassa în $1961^{127}$, I. Paul $1989^{128}$, S. A. Luca din 2010-prezent ${ }^{129}$, dar, din păcate, materiale publicate in extenso din contexte stratigrafice clare/cu caracter închis încă nu există. Practic publicarea materialelor reprezentative din complexele C5/2014 și C53/2014 din siturile de la Tărtăria-Gura Luncii/ Gura Văii Cioarei și Tărtăria - Pietroșița/sit $10 b^{130}$ este foarte importantă în problematica prezenței elementelor de fază Vinča A din sudul Transilvaniei.

În Fig. 13, rezultat al $C A$ aplicată pe unitățile stratigrafice de la Vinča (ad. 9,3-6,5 m) împreună cu cele două complexe de la Tărtăria, se poate observa că cele două unităţi de analiză sud-transilvănene (C5/TartB și C53/Tart) sunt grupate în corelație cu 8.9/V, 8.7/V, G.W/V, G.M/V, G.K/V, unități stratigrafice considerate reprezentative pentru faza a 3-a sitului de la Vinča ${ }^{131}$ echivalată cu sub-faza A2 a culturii Vinča ${ }^{132}$. Astfel, la acest moment al cercetării, cele mai timpurii elemente de tip A ale culturii Vinča pot fi regăsite la Tărtăria, în imediata proximitate a sitului de la Gura Luncii ${ }^{133}$. Subliniem aici încadrarea, de către autorul publicării materialelor, a complexelor C.5/2014 şi C.53/2014 în sub-faza Vinča A3, respectiv A2-A3 ${ }^{134}$. Rezultatele prezente pledează însă, așa cum menţionam mai sus, pentru o încadrare uşor mai timpurie.

Pentru situl de la Tărtăria-Gura Luncii, prezența elementelor de tip Vinča A nu sunt o noutate, ele fiind menționate ca prezente aici în nivelul Ib și încadrate ori ca A3/B1 sau A2 ${ }^{135}$. În consecință nu putem considera surprinzătoare existența la Tărtăria a unor complexe cu materiale de tip Vinča A2, a căror elemente definitorii privind caracteristicile morfologice ale ceramicii sunt în strânsă corelație cu cele din situl eponim al culturii. Problematică rămâne însă încadrarea cronologică pentru unele din complexele din nivelul IV (inferior) din situl de la Tărtăria-Gura Lunciii ${ }^{136}$, propusă de responsabilul științific al celei mai noi etape de cercetare din acest sit, același specialist care a creionat și schema cronologică preliminară pentru situl de la Miercurea Sibiului. Aici folosim exemplul oferit de complexele C. XLV și C. XLIV, complexe încadrate inițial în nivelul IV al schemei stratigrafice de la Tărtăria și atribuite fazei Vinča $\mathrm{A}^{137}$, dar care, ulterior, doar pe baza valorii numerice a unor date AMS sunt „translatate”, tot de S. A. Luca, în nivelul III al sitului (imediat superior nivelului IV) la un moment cronologic contemporan cu faza B, poate C, a culturii Vinča ${ }^{138}$. Aceste încadrări marcate de inconstanță, sugerând o abordare făcută superficial, fac ca orice atribuire cronologică propusă pentru complexele nivelului IV din situl de la Gura Luncii să fie privite cu mari rezerve. Subliniem că suma mărginită a celor cinci date AMS de la Tărtăria, provenite din acest nivel, este într-o foarte bună corelare cu intervalul cronologic la care se află suma mărginită a datelor ${ }^{14} \mathrm{C}$ din etapa IIA2 de la Miercurea Sibiului - Petriș ${ }^{139}$.

Despre alte situri care au fost atribuite fazei A a culturii Vinča, cum ar fi cele de la Romos (încadrare fază A3-B1) ) $^{140}$, Sîntimbru (încadrare fază A2) ${ }^{141}$, Aiud (încadrare fază A2, poate A3) ${ }^{142}$, Hunedoara (încadrare fază A3) ${ }^{143}$, Balomir - Gura Văii Cioarei (fază A) ${ }^{144}$, Limba (încadrare fază A) ${ }^{145}$, cu excepția ultimului sit care prezintă vase ce au caracteristici clare ale fazei Vinča $\mathrm{A}^{146}$, nu putem să ne pronunțăm, dat fiind caracterul descoperirilor respective ${ }^{147}$ și faptul că încadrarea este făcută pe criterii care, cel puțin, la Miercurea Sibiului - Petrişs și Tărtăria - Gura Luncii, s-au dovedit a nu fi corecte.

$\overline{126}$ Horedt $1949,44-57$.

${ }^{127}$ Vlassa 1963, 485-494.

${ }^{128}$ Paul 2011, 19-25.

${ }^{129}$ Dumitrescu-Chioar, Luca, Suciu 2014, 28-34; Luca 2016.

${ }^{130}$ Rogozea 2016; Rogozea 2017.

${ }^{131}$ Schier 1996, 145-146.

${ }^{132}$ Schier 1995, 318, Abb. 146.

${ }^{133}$ Pentru o datare ușor mai timpurie, la orizont de A1b, a complexului C.5/2014 de la Tărtăria - Gura Luncii/Gura Văii Cioareii, vezi Diaconescu, Niț, Suciu in press.

${ }^{134}$ Rogozea 2016, 134 și Rogozea 2017, 15.

${ }^{135}$ Lazarovici, Maxim 1991, 9, 12. Paul 2011, 25 propune o încadrare la orizont de Vinča A1-A2 a acestui nivel.

${ }^{136}$ Luca 2016, 27-28.

${ }^{137}$ Ambele complexe sunt descrise ca fiind suprapuse de locuința L. XV. Luca 2016, 152, 225 pentru complexul C. XLIV și Luca 2016, 142, 225 pentru complexul C. XLV. Locuinţa L. XV este atribuită nivelului IV și încadrată în faza Vinča A (Luca 2016, 225, 234).

${ }^{138}$ Luca et al. 2016, 11. O discuție critică legată de această problemă la Diaconescu 2017.

${ }_{139}$ Pentru comparație vezi fig. 8 din prezentul studiu și Diaconescu 2017, 30, fig. 5.

${ }^{140}$ Luca 1995-1996, 49. Luca et al. 2000, 45 propune o încadrare în faza A și, unele elemente, în sub-faza B1.

${ }^{141}$ Luca et al. 2000, 46.

${ }^{142}$ Luca et al. 2000, 38.

${ }^{143}$ Luca et al. 2000, 39.

${ }^{144}$ Popa 2011, text pl. 11-16.

${ }^{145}$ Florescu 2007, 34-36, fig. 13-17.

${ }^{146}$ Florescu 2007, fig. 13, 15.

${ }^{147}$ Asupra siturilor de la Aiud și Hunedoara ne-am pronunțat mai sus opiniile (vezi n. 52, respectiv n. 56). 


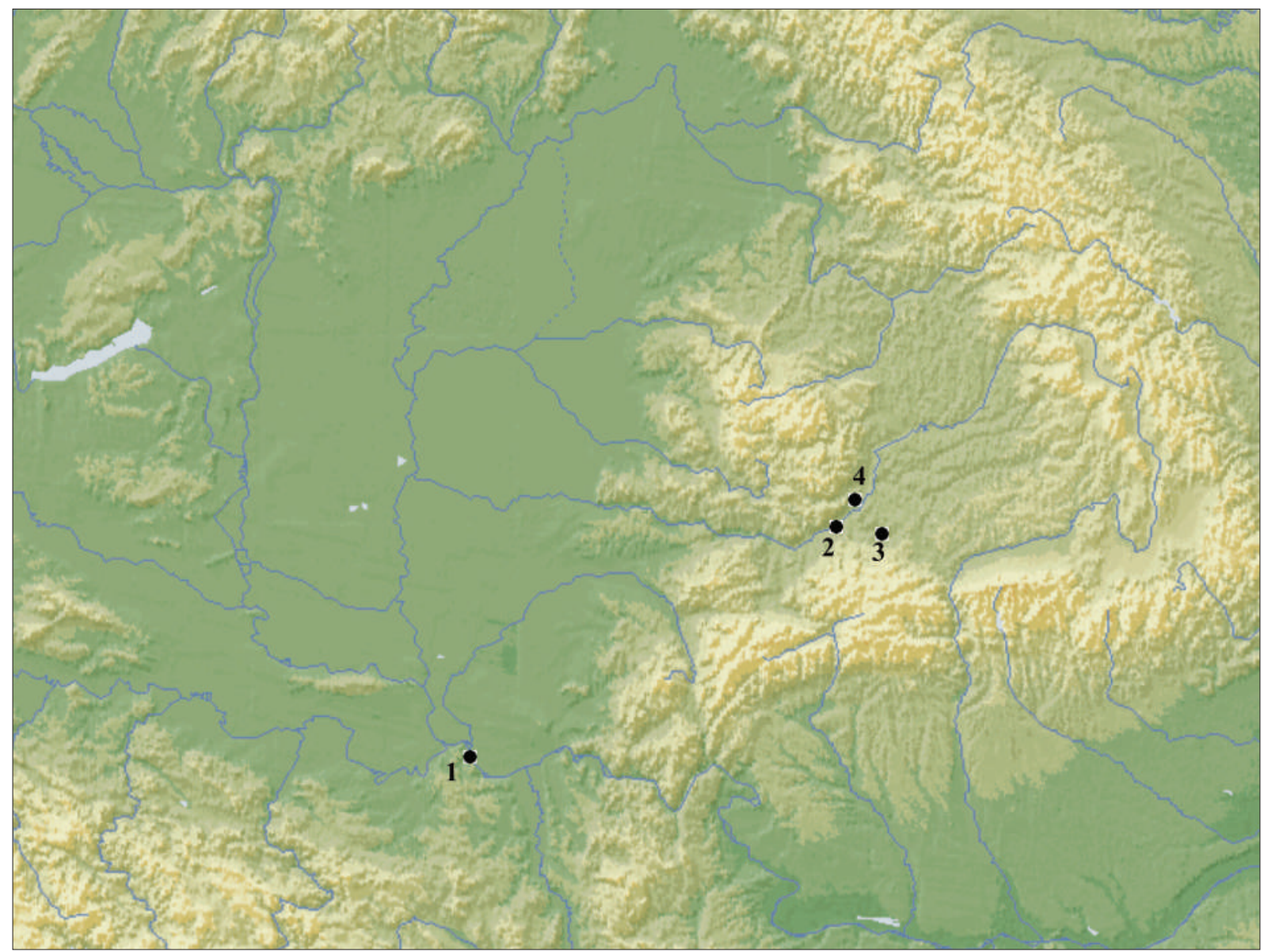

Figura 11. Harta sitului de la Vinča - Belo Brdo și siturilor din Transilvania ce au oferit unități de analiză pentru CA: 1) Vinča - Belo Brdo; 2) Tărtăria - Gura Luncii/Gura Văii Cioarei și Tărtăria - Pietroșița/sit 10b; 3) Miercurea Sibiului - Petriș;

4) Alba Iulia - Lumea Nouă.

\section{Discuții privind grupul Lumea-Nouă}

O primă mențiune a unui complex cultural Lumea Nouă i se datorează lui I. Paul ${ }^{148}$ dar definirea acestuia îi aparține lui I. Berciu ${ }^{149}$. Ulterior, pe baza stratigrafiei de la Tărtăria, ceramica pictată de tip Lumea Nouă ${ }^{150}$, este atribuită nivelului II de la Tărtăria, unde apare în asociere cu ceramică de tip Vinča B1, în sub-nivelul IIa ${ }^{151}$ și, în pondere mai mare, cu analogii în complexul cultural Cluj - Cheile Turzii-Lumea Nouă, în nivelul IIb în asociere cu ceramică de tip Vinča $B^{152}$. Pentru materialele de tip Lumea Nouă de la Zau de Câmpie, Z. Maxim nu vede elemente de locuire ante-Vinča B153. S. A. Luca considera poziția stratigrafică a acestui tip de ceramică pictată ca neclară, referirile la asocierea cu ceramica de tip Turdaş, putând oferi un palier cronologic post-Vinča B2 ${ }^{154}$.

M. Gligor consideră, pe baza cercetărilor de la Alba Iulia - Lumea Nouă, că ceramica pictată de tip Lumea Nouă apare asociată cu ceramică de factură vinčiană (fazele B1-B2) într-o primă etapă și apoi cu ceramică încadrabilă la

\footnotetext{
$\overline{148}$ Paul 1965, 300 (autorul subliniază că la Lumea Nouă și Tărtăria, ceramica pictată de tip Lumea Nouă ,apare întotdeauna în asociere cu ceramică Turdaş, deci în mediu cultural Turdaş, în peșterile de la Cheile Turzii și în peștera Devențului a fost găsită numai ceramică de tip «Lumea Nouă», fără elemente Turdaș”). De subliniat modul în care Iuliu Paul vede cultura Turdaş (vezi supra n. 35).

149 Berciu 1968, 57-58. Denumit și facies (vezi Vlassa 1976, 128, 132-133) sau grup (Lazarovici 1991d, 111-114). Grupul Lumea Nouă este încorporat în complexul cultural Cluj-Cheile Turzii-Lumea Nouă-Iclod (Lazarovici 1991e, 100).

${ }^{150}$ Numită inițial de tip D1a (vezi Berciu, Berciu 1949, 9-11, fig. 6/1, 4-6, 8, 10-12 şi fig. 7).

${ }^{151}$ Lazarovici, Maxim 1991, 12.

${ }^{152}$ Lazarovici, Maxim 1991, 10. Aceeași opinie și la Maxim 1999, 64. Complexul cultural cu pricina, prescurtat CCTLNI, este văzut ca evoluând în trei etape, prima dintre ele, numită B.I., fiind compusă din descoperiri de tip Cluj, Cheile Turzii, Lumea Nouă, Pișcolt și situată la un palier cronologic Vinča A2/A3-B1 (Maxim 1999, 69).

${ }^{153}$ Maxim 1999, 75. Lazarovici 2009, 183 vede însă toată faza I a culturii Zau, contemporană cu etapele Vinča A 2 și A3 (opinii similare la Lazarovici 2010, Lazarovici, Lazarovici, Merlini 2011, Lazarovici 2014).

${ }^{154}$ Luca 1999, 10. Text identic, tot în limba română la Luca 2006b, 24; Luca 2006a, 353. Text identic, tot în limba engleză, la Luca, Diaconescu, Suciu 2008, 28-29.
} 


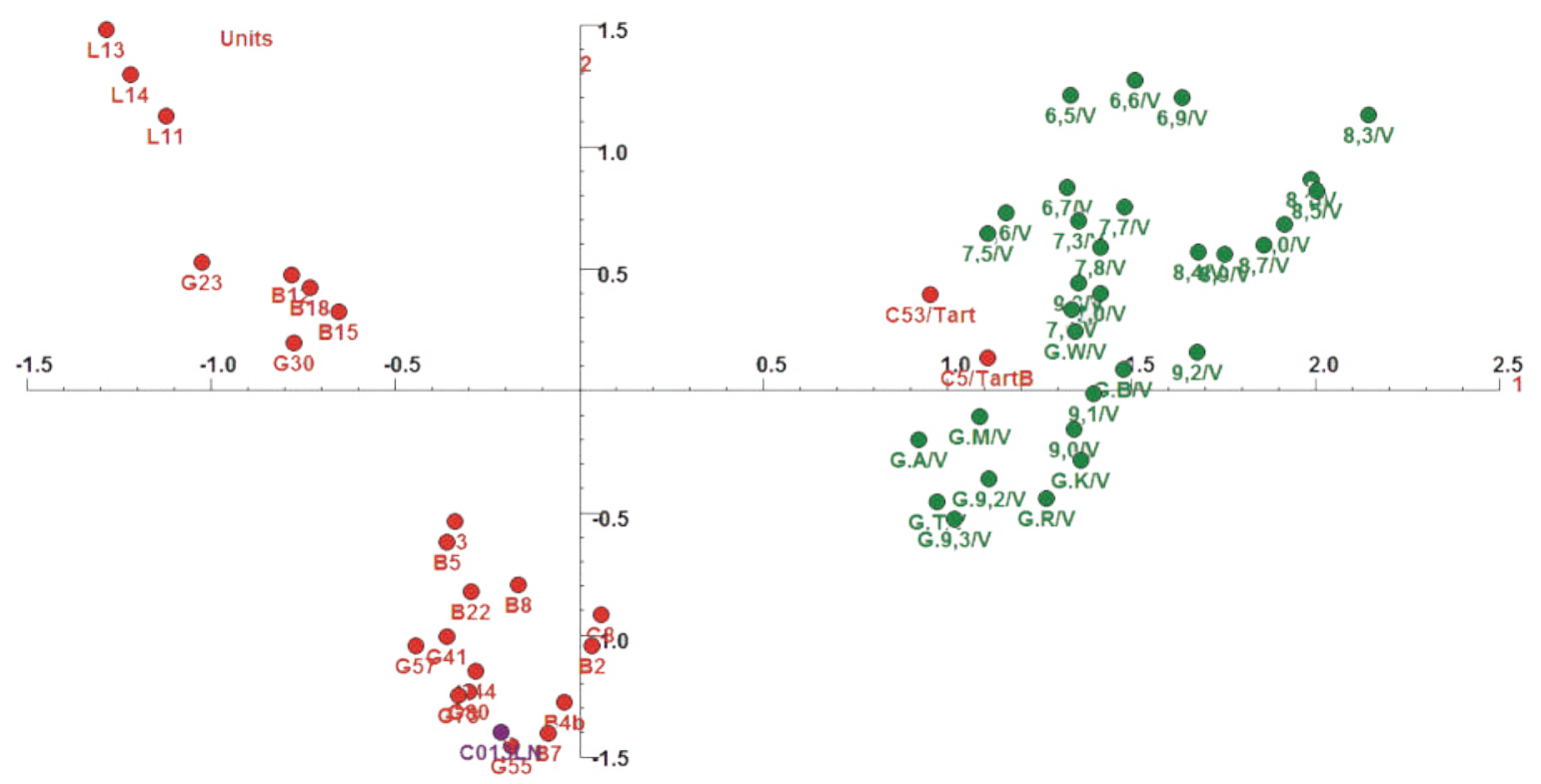

Figura 12. Rezultatele CA aplicată pe complexe/unități stratigrafice provenind din patru situri transilvănene și de la Vinča - Belo Brdo.



A3

Figura 13. Rezultatele CA aplicată pe unitățile de analiză din cadranele I și IV ale graficului din fig. 12. 
orizont de Vinča B2/C - Vinča C, propunând în esenţă o divizare în două faze a grupului Lumea Nouă ${ }^{155}$. Acelaşi autor afirmă că în partea superioară a nivelului Vinča din situl de la Alba Iulia, ceramică de tip Turdaș apare, sporadic (în text: „rarely”), în asociere cu ceramică de tip Lumea Nouă ${ }^{156}$. Cele două etape din cadrul grupului Lumea Nouă sunt numite I (ceramică bicromă cu motive constând în benzi de linii și decor perlat/ghirlande şi ceramică tricromă cu motive de tip benzi simple) şi II (numită și clasică, în care se constată generalizarea picturii tricrome în special a motivelor în arcadă) ${ }^{157}$.

Legat de materialele pictate de tip Lumea Nouă de la Miercurea Sibiului, constatăm că fragmentele provenite din B4b fac parte din categoria picturii bicrome, ornamentată cu bandă lată verticală, de culoare brun-deschis pe fond alb-gălbui, dispusă pe o strachină tronconică cu buză lobată și cu pereții ușor arcuiți spre exterior ${ }^{158}$, care are, aşa cum precizam mai sus, analogii extrem de bune în așezarea de la Alba Iulia-Lumea Nouă. Vasul de la Lumea Nouă este încadrat în categoria ceramicii bicrome, prezentând însă, spre deosebire de fragmentele de la Miercurea Sibiului, pictură și la interior. În mod special decorul de la interior este considerat ca aparținând unei etape ce aparține unui palier cronologic de nivel Vinča B2 ${ }^{159}$. Este însă clar că, din punct de vedere tipologic, vasul fragmentar din bordeiul B4b de la Miercurea Sibiului se încadrează în faza I a grupului Lumea Nouă, așa cum a fost definită de M. Gligor, însă la un moment cronologic absolut Vinča B1.

Un alt fragment ceramic de tip Lumea Nouă a fost identificat în complexul G44 de la Miercurea Sibiului-Petriş ${ }^{160}$ şi provine dintr-un vas bitronconic, a cărui zonă maximă de dezvoltare este marcată printr-o nervură orizontală profilată, pe care este dispus un buton semisferic (cel mai probabil vasul avea patru asemenea butoni). Decorul, pictat cu brun-vișiniu pe un fond alb-gălbui, este compus în partea superioară a vasului dintr-o bandă lată orizontală asociată buzei, o bandă lată verticală ce pleacă de deasupra butonului și se întâlnește cu banda orizontală asociată buzei. Banda lată verticală este flancată spre stânga de o altă bandă verticală, simplă, îngustă, iar spre dreapta de un motiv pictural mai complex format din două benzi simple, înguste, verticale care cuprind în spațiul dintre ele benzi orizontale perlate. Partea inferioară a vasului este decorată din benzi subțiri și late, verticale, dispuse alternativ față de motivele ornamentale de partea superioară a vasului. Pictura bicromă și motivele ornamentale descrise sunt deasemenea caracteristice fazei I a grupului Lumea Nouă. Complexul G44 intră în aceeaşi etapă cu complexul B4b, fiind contemporan, cronologic absolut, cu faza Vinča B1.

Foarte important în discuția de faţă este și vasul descoperit în relaţie cu locuința L13 de la Miercurea Sibiului, considerat un import cultural ${ }^{161}$. Analogiile identificate îl determină pe primul autor al studiului în cauză să încadreze acest vas în faza III a grupului Pișcolt ${ }^{162}$. Luând în calcul faptul că acest vas are suprafața acoperită de o angobă albă, cu aspect văros, de proastă calitate, căzută în cea mai mare parte, fapt care duce și la dispariția unui bune părți din decorul pictat, îl putem pune în legătură într-adevăr cu etapa târzie (III) a grupului Pișcolt, așa cum a fost ea definită ${ }^{163}$. Cele mai bune analogii pentru forma de vas, tipul de angobă folosit, dar și pentru motivul pictural, compus din benzi în arcade formate din linii subțiri, însoțite în duct paralel de benzi late, pictate cu negru,

\footnotetext{
$\overline{155}$ Gligor 2007a, 175-176. O opinie mai tranșantă legată de cele două faze la Gligor 2009, 69, 161.

${ }^{156}$ Gligor 2007b, 44.

157 Gligor 2009, 69.

${ }^{158}$ Suciu 2009, fig. 123/f.

159 Gligor 2009, 67.

${ }^{160}$ Vezi descrierea acestuia la Suciu 2009, 174.

${ }^{161}$ Luca, Diaconescu, Suciu 2011.

${ }^{162}$ Luca, Diaconescu, Suciu 2011, 25. Suciu 2009, 174 vede analogii pentru acest vas în materialele de la Blaja-Grind Cehal, fără a oferi însă vreo trimitere bibliografică către materialul respectiv. Acesta a fost publicat de Virag 2007, iar vasul de la pl. 9/6 din această sursă este citat de Luca, Diaconescu, Suciu 2011, 25 ca o bună analogie pentru motivul ornamental; subliniem că nu considerăm respectiva analogie ca cea mai potrivită datorită faptului că liniile subțiri nu formează benzi bine individualizate, ci sunt plasate mai rar umplând uniform spațiul dintre benzile late. Același lucru se poate spune despre descoperirile de la Porț-Corău (Băcueț-Crișan 2008, 21, pl. 4/6, pl. 5).

163 Lazarovici, Németi 1983, 33. Colesniuc 2014, 116 consideră vasul din L13 de la Miercurea Sibiului ca aparținând mai degrabă culturii Zau (probabil faza IC având în vedere poziția discuției respective în economia lucrării) decât grupului Pișcolt, folosind ca argument prezența restului de angobă albă de pe suprafața exterioară a vasului (?). Aici ne rezumăm doar să cităm din Lazarovici, Németi 1983, 33, atunci când sunt definite caracteristicile ceramicii fazei Pișcolt târzii (III): „Suprafaţa vaselor nu mai are luciul metalic al neoliticului mijlociu, din care motive se folosește tot mai des angobarea cu alb.... Această angobare este de proastă calitate, fiind slab arsă sau doar calcinată din care motive cade sau cade pictura, reconstituirea ei fiind adeseori dificilă... Angobarea cu alb, ca fond pentru pictură, este des întâlnită, dar sub forma unor urme sporadice”. Lazarovici, Lazarovici 2015, 11, încadrează acest vas de la Miercurea Sibiului, fără nici un argument clar definit, într-o etapă Pișcolt IIB, considerând mediul cultural în care este prezent ca Vinča B. Această etapă IIB, nedefinită la Lazarovici, Németi 1983 o întâlnim la Băcueț-Crișan 2008, 23 paralelizată cu fazele Vinča B1/B2 (i.e. sf. B1b-înc. B2 sistem Schier) sau la Lazarovici 2014, 22 unde această etapă este văzută ca fiind contemporană cu faza 5b de la Belo Brdo (i.e subfaza B1b cronologie Schier) sau Vinča B1/B2 (cronologie Lazarovici).
} 
le găsim în groapa nr. 1 de la Vărzari ${ }^{164}$ și Pișcolt - SMA/Cărămidărie ${ }^{165}$. Forma patrulateră a corpului vasului, dacă este privită de deasupra ${ }^{166}$ și prezența unei adâncituri orizontale care marchează zona de demarcație a gâtului de corpul vasului sunt deasemenea elemente morfologice caracteristice ceramicii grupului Pișcolt ${ }^{167}$. Orizontul cronologic al acestor descoperiri de tip Pișcolt târziu este situat la nivel de Vinča B2/C-C1 (i.e. Vinča C1-C2 în cronologia Schier), post Tărtăria $\mathrm{II}^{168}$. Orizontul cronologic relativ propus pentru acest tip de descoperiri, raportat la sistemul cronologic absolut al culturii Vinča ar putea fi poziționat la palierul de cca 5000-4850 cal BC ${ }^{169}$. Relativ recent, materialele de la Vărzari sunt considerate contemporane/integrate etapei Pișcolt IIIA, la nivel de Zau IIIA, faza 6 Belo Brdo/Vinča C1 (cronologie Schier), etapă datată absolut la cca 5050-4950 cal BC ${ }^{170}$.

S. A. Luca consideră, relativ de curând, că, de fapt, plecând de la datarea absolută a locuințelor de suprafață de la Miercurea Sibiului, vasul cu pricina din locuința L13 nu ar aparține grupului Pișcolt, ci grupului Lumea Nouă şi că datarea propusă (de data asta Pișcolt II/III sau III), cităm ,.....arată doar faptul că - tipologico-stilistic - el este, la Miercurea Sibiului, cu cele mai vechi elemente ale grupului Pișcolt" ${ }^{\prime 11}($ ?). Locuința L13, împreună cu L11 și L14, fac parte din clusterul IIB al analizei $C A$ de mai sus (Fig. 6a), cluster care nu beneficiază de date ${ }^{14} \mathrm{C}$ viabile, dar care, conform modelării bayesiene, are ca terminus post quem intervalul cronologic absolut determinat pentru clusterul IIA2 (i.e. cca 5060-4975 cal BC), aspect susținut și de determinarea aproximativă a intervalului cronologic absolut, plecând de la palierul cronologic relativ stabilit (vezi mai sus). Astfel putem considera că, analogiile pentru vasul din L13, în mediu Pișcolt III sunt corecte, la un palier cronologic relativ contemporan cu Vinča B2/C-C1 (cronologie Lazarovici), datat la cca 5000-4900 cal BC, aserțiune susținută și de poziția etapei IIB de la Miercurea Sibiului în cadrul rezultatelor $C A$ (post cluster IIA2).

O ultimă discuție este necesară în cazul unui fragment ceramic, provenit tot de la Miercurea Sibiului, ale cărui elemente decorative au fost incluse în tipul Lumea Nouă/Zau ${ }^{172}$. Acest fragment ceramic este atribuit prin textul explicativ al unei figuri ${ }^{173}$ complexului/gropii Gr16. Aici trebuie să ne manifestăm nedumerirea, pentru că nu cunoaştem care este complexul/groapa 16 la care face referire S. A. Luca. Din campania 2003, inclusiv, documentaţia grafică a șantierului de la Petriș fost întocmită de D. Diaconescu, în calitate de nou membru/responsabil de sector al echipei de cercetare. Conform numerotării complexelor, unitatea stratigrafică de tip adâncit cu nr. 16 ar fi trebuit să fie cercetată în suprafața S.I/2001-2003, cel mai probabil în campania 2003. Pe nici unul dintre planurile întocmite ale acestei unități de cercetare nu există complexul G16/Gr16 $6^{174}$. Revenind însă la fragmentul ceramic, căruia nu îi cunoaștem contextul, constatăm că este decorat în tehnica picturii tricrome, specifică aşa-numitului

\footnotetext{
${ }^{164}$ Ignat 1982, pl. II; Ignat 1999-2000, table II/3, 4 (pentru forma de vas) și Ignat 1999-2000, table III/2, V/3.

${ }_{165}$ Bune analogii pentru motivul pictural la Lazarovici, Németi 1983, fig. 19/2. Németi 1986-1987, 34-36, încadrează de asemenea descoperirile din groapa nr. 2 de aici în etapa Pișcolt târzie.

${ }^{166}$ Luca, Diaconescu, Suciu 2011, 24, photo 9.

167 Virag 2004, 50; Lazarovici, Németi 1983, 29, 33; Ignat 1982, 361.

${ }^{168}$ Lazarovici, Németi 1983, 35. Sistemul cronologic pentru cultura Vinča este cel al lui Gh. Lazarovici. O opinie asemănătoare, referitoare la palierul cronologic pentru faza III (târzie) a grupului Pișcolt, la Băcueț-Crișan 2008, 23 care plasează la debutul fazei III etapa Vinča B2 iar la finalul ei etapa Vinča C (dacă plecăm de la premisa folosirii de către autoare a sistemului cronologic Lazarovici, palierul propus ar fi în sistemul Schier Vinča B2-sf. C1/înc. C2).

${ }^{169}$ Raportarea s-a făcut la digrama propusă de Whitle et al. 2016, fig. 37.

${ }^{170}$ Lazarovici 2014, 25.

${ }^{171}$ Luca 2016, 243-245. Din păcate datarea absolută a locuințelor de suprafață de la Miercurea Sibiului, este presupusă de S. A. Luca, nu pe baza datei GrN-29053: 6350 130 BP, care provine conform lui Biagi 2015, 245 din locuința 11 (această unitate stratigrafică, ca și L13 și L14, oferă materiale doar din nivelul de călcare aferent acestor locuințe, care nu au fost distruse prin incendiere; probabilitatea ca și calcaneum-ul de bovideu din care provine proba să fie intruzivă în acest caz este foarte mare, fapt argumentat conjunctural și de valoarea numerică a datei, iar deviația standard foarte lungă face ca data în cauză să nu fie viabilă pentru estimarea cronologiei absolute a nivelului IIb din situl de la Miercurea Sibiului-Petriş). Dacă lecturăm cu atenție textul constatăm că Luca 2016, 251 ne spune că, de fapt, data GrA-43076: 6160 \pm 50 BP (din B18 n.n.) este obținută dintr-o probă ce provine „dintr-o amenajare ce ține de locuința de suprafață aparținând nivelului IIb”. Amenajarea cu pricina este de fapt locuința L11, care suprapune B18. Plecând de la valoarea numerică a acestei date, neluând în calcul detaliile stratigrafice ale probei, și bazându-se și pe cronologia relativă a nivelului IIb propusă (i.e. Vinča A3-B1) este foarte clar de ce S. A. Luca nu mai dorește ca vasul din locuința L13 să fie încadrat/încadrabil în faza Pișcolt III, fază plasată, așa cum am văzut mai sus, la nivel de final de fază B2, început de fază C. De aceea, chiar dacă tipologico-stilistic vasul cu pricina chiar are analogii foarte bune în ceramica de tip Pișcolt III, S. A. Luca pare derutat (aspect subliniat și de structura frazei citate de noi) și trimite acest vas, pe criterii tipologico-stilistice [sic!] ştiute doar de domnia-sa, înspre orizonturile cele mai vechi (timpurii) ale acestui grup cultural (?). Autorul continuă să afirme că şi dacă vasul respectiv ar fi de tip Lumea Nouă, ar trebui să fie vorba de un orizont mai vechi (Luca 2016, 244).

${ }^{172}$ Luca 2016, 241

${ }^{173}$ Luca 2016, 241, fig. 253.

${ }^{174}$ Cel mai elocvent exemplu este planul din Suciu 2009, 89, fig. 117 al complexelor adâncite aparținând culturii Vinča, unde acest complex nu este de găsit.
} 
grup cultural Lumea Nouă ${ }^{175}$, prin decorul pictat pe un fond alb-gălbui cu bandă lată de culoare roșiatică, peste care sunt aplicate linii subțiri de culoare neagră, grupate doar pe suprafața benzii roșiatice. Motivul ornamental este unul în arcadă, cu bune analogii la Alba Iulia-Lumea Nouă ${ }^{176}$. Conform sistemului evolutiv pentru acest tip de ceramică, propus de M. Gligor, acest fragment ceramic aparține fazei a II-a, evoluată, caracterizată în special de pictură tricromă, organizată în arcade ${ }^{177}$. Din păcate lipsa unui context stratigrafic clar/cert pentru acest fragment îl face inutilizabil într-o dorită discuție referitoare la prezența ceramicii de tip Lumea Nouă în cadrul structurii interne a sitului de la Miercurea Sibiului - Petriș.

\section{Concluzii}

Utilizarea analizei de corespondență $(C A)$ în evaluarea caracteristicilor morfologice ale ceramicii aparținând culturii Vinča, în special din Transilvania, ne oferă posibilitatea să subliniem câteva aspecte foarte interesante.

Faza Vinča A este prezentă în Transilvania și prezintă caracteristici tipologico-stilistice asemănătoare unităților stratigrafice ce aparțin sub-fazei Vinča A2 (i.e. faza 3) din cadrul sitului de la Belo-Brdo ${ }^{178}$. Complexele de la Tărtăria - Gura Luncii/Gura Văii Cioarei și Tărtăria - Pietroșița/sit 10 b aparțin acestui orizont. Aceste descoperiri, deși flanchează situl de la Tărtăria - Gura Luncii, nu conțin, la stadiul publicării lor actuale (și aici ne referim strict la cele două complexe arheologice utilizate în analiza prezentată aici), elemente de tip Lumea Nouă. Materiale ceramice de la Limba - Bordane sau Limba-Vărărie prezintă, la o analiză macroscopică, caracteristici tipologicostilistice tipice pentru faza $\mathrm{A}^{179}$. Chiar dacă se afirmă că la Limba-Bordane apare ceramică de tip Lumea Nouă, considerată de fază Zau IB, împreună cu ceramică Vinča A $3^{180}$, un studiu al autorului cercetărilor de aici, arată că materialele Lumea Nouă abordate în articolul respectiv, sunt descoperite de fapt în mediu Vinča B ${ }^{181}$. Astfel, sincronismele propuse, începând din 2009, de Gh. Lazarovici pentru faza IB a culturii Zau cu faza 3 a sitului de la Vinča - Belo Brdo (i.e. faza Vinča A2) ${ }^{182}$, bazate, cronologic relativ în mod special pe asocierea artificială a două vase din situl de la Limba - Bordane ${ }^{183}$, nu mai pot fi susținute la acest moment. Analiza bayesiană a datelor ${ }^{14} \mathrm{C}$ din situl de la Zau de Câmpie, într-un context mai larg, a dus la concluzia că, din punct de vedere cronologic absolut, etapele Zau IB-IC nu pot fi sincronizate cu faza A a culturii Vinča, ci cu mijlocul fazei B ${ }^{184}$.

La Miercurea Sibiului - Petriș, materialele pictate de tip Lumea Nouă, provenite din contexte stratigrafice certe, apar în complexe (B4b și G44), aparținând etapei IIA1 a nivelului habitaţional II, a cărei cronologie absolută este situată la acelaşi palier cu sub-faza B1 a culturii Vinča.

Cronologia internă a sitului de la Petriş cuprinde trei etape (IIA1, IIA2 și IIB). Nu există până la acest moment descoperiri de fază A în acest sit. Comparația directă a materialului de aici cu cel de la Vinča - Belo Brdo arată o disociere clară de materialul de fază B din situl eponim (i.e. ad. 7,8-6,5 m). Pe baza datelor de cronologie absolută putem propune sincronismele Miercurea Sibiului IIA1 = Vinča B1/înc. B2, Miercurea Sibiului IIA2 = Vinča B2. Este clar că Miercurea Sibiului IIB are ca terminus post quem etapa IIA2 din acelaşi sit, astfel că pe această bază, cu prudența de rigoare, putem considera că Miercurea Sibiului IIB = sf. Vinča B2/înc. C1. Conjunctural, data ${ }^{14} \mathrm{C}$ din complexul G83 de la Miercurea Sibiului (Poz-61041) are valoarea calibrată $2 \sigma$ de 5061-4718 cal BC, iar pe cea $1 \sigma$ de 4981-4800 cal BC), care este cea mai târzie din nivelul ocupațional aparținând culturii Vinča din acest sit, poate fi relaţionată cu etapa IIB a nivelului vinčian, prelungindu-i palierul cronologic absolut către cca 4875 cal BC, perioadă ce corespunde debutului celei mai consistente marje temporale pentru faza Vinča $\mathrm{C}^{185}$.

\footnotetext{
$\overline{175}$ Gligor 2009, 68 .

${ }^{176}$ Gligor 2009, pl. CLXXIII/9; CLXXV/2.

177 Gligor 2009, 69.

178 În Diaconescu, Nițu, Suciu in press complexul C.5 de la Tărtăria-Gura Luncii/Gura Văii Cioarei este integrat în sub-faza A1b, asociat însă în același cluster şi cu groapa G.W/V, care aparține, în analiza lui Schier (Schier 1996, fig. 2), fazei 3 a sitului de la Belo Brdo.

${ }^{179}$ Florescu 2007, 34-35, cat. no. 13-16; Ciută, Ciută 2015, fig. 9, 10, 11, 13.

${ }^{180}$ Lazarovici 2010, 115; Lazarovici 2014, 16, 17 citând Florescu 2007, cat. 13 și Gligor 2007b, cat. 28, consideră cele două vase ca provenind din același complex [sic!].

${ }^{181}$ Ciută, Ciută 2015, 62, fig. 18 încadrează ceramica din L1/1996 în faza Vinča B1, iar la p. 71 bordeiul din SIX/1997, unde este descoperit un vas de tip Lumea Nouă (fig. 32 - i.e. Gligor 2007b, nr. cat. 28) este încadrat în faza B a culturii Vinča B1. Vasul de la Florescu 2007, nr. cat. 13 îl găsim la Ciută, Ciută 2015, 61, fig.13 încadrat în Vinča A2 și provenind dintr-o locuință de suprafață abordată în unitățile de cercetare SX/1998 și SXI/1999.

${ }^{182}$ Lazarovici 2009, 183; Lazarovici 2010, 116, fig. 2; Lazarovici, Lazarovici, Merlini 2011, 81, Table IV.32; Lazarovici $2014,16$.

${ }^{183}$ Vezi mai sus n. 181.

${ }^{184}$ Drassovean 2014, 39.

${ }^{185}$ Conform Whittle et al. 2016, 40, fig. 37.
} 
Includerea în $C A$ a unor complexe provenite din două situri de la Tărtăria și din situl de la Alba Iulia-Lumea Nouă, ne arată că orizontul Vinča A din Transilvania are aceleași caracteristici cu cel din zona Dunării mijlocii, iar materialul de palier cronologic Vinča B din Ardeal arată o clară disociere de materialele arondate fazei B din situl eponim. Prezența elementelor de tip Lumea Nouă și în complexul C.013/2014-2015 de la Alba Iulia-Lumea Nouă, unitate stratigrafică care converge foarte bine cu etapa IIA1 de la Miercurea Sibiului, ne arată că disocierea materialelor de tip Vinča B din Transilvania față de cele de la Belo Brdo este în strânsă legătură cu prezența elementelor pictate de tip Lumea Nouă. Importul de tip Pișcolt III de la Miercurea Sibiului, provenit din etapa IIB a sitului, converge foarte bine cu datele de cronologie relativă propuse pentru această fază a grupului Pișcolt.

Poziția materialelor de la Miercurea Sibiului, în primul rând, față de cele de la Belo Brdo readuce în discuție problematica variantei transilvănene a culturii Vinča, dar doar de la momentul fazei B a acestei culturi. Această situație poate fi explicată doar printr-o întrerupere a legăturilor culturale dintre Transilvania și arealul Dunării mijlocii undeva la finalul fazei A a culturii Vinča (i.e. cca 5200 cal BC), întrerupere care determină/este determinată de apariția ceramicii de tip Lumea Nouă în mediul cultural vinčian.

Această regionalizare a fost sesizată și menționată în literatura de specialitate fiind folosit termenul de variantă transilvăneană a culturii Vinča ${ }^{186}$. Relativ recent două opinii ale istoriografiei românești au oferit două variante denominative alternative. Prima dintre ele, propune, ca titulatură provizorie, pentru această variantă a culturii Vinča, termenul de ,aspectul turdășean al culturii Vinča”187. Cea de-a doua, propune, considerând că la orizont de Vinča B se produce o regionalizare culturală, termenul de „Lumea Nouă (cultura Zau, mai nou)"188. Nu putem să fim de acord cu nici una dintre aceste propuneri. Pentru propunerea făcută de I. Paul, subliniem din nou că la Turdaș nu există elemente mai timpurii de palierul cronologic al fazei $\mathrm{C}$ a culturii Vinča, deci aspectul turdășean devine un termen caduc, pentru manifestările vinčiene din Transilvania. Opinia lui S. A. Luca nu are substanță pentru că elementele de tip Lumea Nouă de la Tărtăria sunt considerate importuri ale culturii Zau ${ }^{189}$. Totodată elementele de tip Lumea Nouă de la Tărtăria și Alba Iulia-Lumea Nouă au fost considerate ca provenind din mediu Vinča (numit în 1965 Turdaș), iar în cazul peșterilor din Cheile Turzii și Devenț elementele de tip Vinča lipsesc ${ }^{190}$, același lucru fiind afirmat și pentru situl de la Zau de Câmpie ${ }^{191}$. Un argument solid pentru considerarea ceramicii pictate de tip Lumea Nouă ca import în situri vinčiene este oferit chiar de situl de la Miercurea Sibiului. Aici, au apărut fragmente ceramice pictate de tip Lumea Nouă doar în trei contexte stratigrafice (G44, B4b şi, incert, G16), restul ceramicii (cu excepția importului Pișcolt III din L13) oferind date morfologice caracteristice produselor de olărit specifice culturii Vinča.

Pentru situl de la Tărtăria-Gura Luncii, cea mai recentă publicație referitoare la acest sit, care pune în circuitul științific rezultatele cercetărilor preventive, ca urmare a amenajării căii ferate rapide (pe axă aproximativ E-V), pe o lungime de peste 256 metri, fiind cercetate peste 100 de complexe ${ }^{192}$, ne prezintă, publicate, fragmente ceramice pictate de tip Lumea Nouă din 9 complexe (8 cu câte un fragment ceramic pictat - L.III, C.XXXVIII, C.IV, C.VI, C.X, L.XIII, C.XC, C.LXXXIX şi 1 complex cu 5 fragmente ceramice pictate - L.XVI ${ }^{193}$. Patru dintre aceste complexe sunt atribuite fazei A (C.XXXVIII, C.IV, C.VI, C.X), două fazei A3/B1 (C.XC, C.LXXXIX) și trei fazei B (L.III, L.XIII, L.XVI) ${ }^{194}$. Nu insistăm aici asupra valențelor eventual cronologice ale diverselor motive ornamentale ${ }^{195}$, dar dorim să subliniem numărul mic de fragmente ceramice de tip Lumea Nouă și în cadrul sitului de la Tărtăria, aspect care subliniază presupusul caracter de import al acestui gen de materiale în siturile vinčiene din Valea Mureșului mijlociu' ${ }^{196}$.

\footnotetext{
${ }^{186}$ Garašanin 1979, 181-194; Chapman 1981, 21-22, 29-30; Garašanin 1982, 124-126; Maxim 1999, 63 care numește acest fenomen, aspectul transilvănean al culturii Vinča.

${ }_{187}$ Paul 2011, 25

${ }^{188}$ Luca 2016, 238. Asta chiar dacă tot în Luca 2016, 25 cercetătorul sibian susține că pictura de tip Lumea Nouă (Zau) apare în mai multe situri transilvănene, inclusiv Miercurea Sibiului, la un moment Vinča A2-A3 (la Miercurea Sibiului este menționată etapa II/III care conține acest tip de materiale), explicând cititorilor și că "pictura se asociază cu ceramica vinciană şi în faza B a aceleiași culturi”. În acest caz nu ne putem explica teoria regionalizării propuse de S. A. Luca la nivel de Vinča B, câtă vreme elementele Lumea Nouă, conform opiniei acestuia, ar apărea deja de la un moment A2-A3.

${ }^{189}$ Lazarovici, Lazarovici 2006, 410; Lazarovici, Lazarovici, Merlini 2011, 77.

190 Paul 1965, 300. Pentru Cheile Turzii-Peștera Ungurească este subliniată prezența, în proporție de 30\%, a ceramicii pictate şi lipsa ceramicii incizate (cf. Maxim 1999, 72).

${ }^{191}$ Lazarovici, Lazarovici, Merlini 2011, 367.

${ }^{192}$ Luca 2016.

${ }^{193}$ Luca 2016, 159, fig.: 7/3; 42/3; 46/3; 57/1; 61; 69; 137; 149; 158; 159.

${ }^{194}$ Luca 2016, 213. Conform autorului „această specie pictată apare atât la orizont Vinča A (L.XVI; C.IV; C.VI; C.X, dar și în zona de nord-est: C.XC și C.LXXXIX), cât și la orizont Vinča B (L.II [sic!] și L.XIII)”.

${ }^{195}$ Precizăm totuși că pictura tricromă, considerată de M. Gligor ca specifică etapei mai târzii apare în complexe încadrate în fazele Vinča A (C.XXXVIII, C.IV, C.VI) sau Vinča B (L.III, L.XVI), la fel ca pictura cu benzi simple sau motive perlate, specifică unui orizont mai timpuriu (C.X - pentru Vinča A și L.XIII - pentru Vinča B).

${ }^{196}$ Materiale de acest gen apar și în situl de la Șoimuș-Avicola (vezi Ștefan, Petcu, Petcu 2013, 52, pl. XI/1, 2).
} 
De aceea, preferăm pentru acest aspect regional al culturii Vinča, regionalizare petrecută la orizont de fază B a culturii, denumirea de varianta transilvăneană a culturii Vinča.

\section{Mulțumiri}

Aplicarea analizei de corespondență în cazul Miercurea Sibiului-Petriș nu ar fi fost posibilă fără excelenta activitate a regretatei noastre colege dr. Florina Maria (Nina) Nițu, în ceea ce privește ceramica vinčiană de aici. Lucrările Ninei se constituie într-o adevărată "coloană vertebrală,, pentru demersul de faţă. Nu există cuvinte prin care să ne exprimăm gratitudinea pentru munca depusă ${ }^{197}$. Mulțumim colegului Mihai Gligor pentru permisiunea acordată de a analiza nemijlocit caracteristicile morfologice ale ceramicii Vinča din complexul C013/2014-2015 de la Alba Iulia-Lumea Nouă și pentru toate informațiile despre acest complex, oferite cu generozitate. Nu în ultimul rând dorim să mulțumim lui Tomasz Goslar şi echipei sale de la laboratorul din Poznan pentru excelenta calitate a muncii lor.

\section{BIBLIOGRAFIE}

Băcueț-Crișan 2008

Berciu 1961

Berciu 1968

Berciu, Berciu 1949

Biagi 2015

Bronk Ramsey 2009

Chapman 1981

Childe 1929

Ciugudean 1978

Ciugudean 1979

Ciută 2004

Ciută 2009
Băcueț-Crișan, S., Descoperiri ale grupului Pișcolt în județul Sălaj, Acta Musei Porolissenis, XXX, 2008, 11-51.

Berciu, D., Contribuții la problemele neoliticului în România în lumina noilor cercetări, Editura Academiei Republicii Populare Române: București, 1961.

Berciu, I., Importanța complexului neolitic Lumea Nouă în lumina noilor săpături (1961-1963), Apulum, VII/1, 1968, 53-58.

Berciu, D., Berciu, I., Săpături şi cercetări arheologice în anii 1944-1947, Apulum, III, 1949, 1-43.

Biagi, P., The Middle Neolithic and Chalcolithic chipped stone assemblages of Transylvania: their exploitation, manufacture and Trans-Carpathian Trade, in S. Hansen, P. Raczky, A. Anders, A. Reingruber (eds.), Neolithic and Copper Age between the Carpathians and the Aegean See. Chronologies and Technologies from the 6th to the 4th Millennium BCE, International Workshop Budapest 2012, Archäologie in Eurasien 31, Habelt Verlag: Bonn, 2015, 243-262.

Bronk Ramsey, C., Bayesian analysis of radiocarbon dates, Radiocarbon, 51 (1), 2009, 337-360.

Chapman, J., The Vinča Culture of South East Europe. Studies in chronology, economy and society, BAR International Series, 117, 1981.

Childe, V. G., The Danube in prehistory, Clarendon Press: Oxford, 1929.

Ciugudean, H., Săpăturile de salvare de la Aiud-Cetățuie, Acta Musei Napocensis, XV, 1978, 49-62.

Ciugudean, H., Noi descoperiri arheologice pe teritoriul județului Alba (II), Apulum, XVII, 1979, 65-86.

Ciută, M. M., Contribuţii la repertoriul descoperirilor aparţinând fazelor timpurii ale culturii Vinča din sud-vestul Transilvaniei, Patrimonium Apulense, IV, 2004, 29-35.

Ciută, M. M., Precizări cu privire la topografia, toponimia, stratigrafia și sectoarele complexului de așezări de la Limba-Oarda de Jos (jud. Alba), Apulum, XLVI, 2009, 335-362.

\footnotetext{
${ }^{197}$ Studiul Diaconescu, Nițu, Suciu in press, care vizează un spațiu geografic mai larg, o are drept coautor pe colega noastră. În cazul demersului de față, în care discuțiile fiind mai concentrate pe Transilvania, unele dintre ele având și un puternic caracter critic, am considerat mult mai potrivit să nu îi expunem memoria, în mod gratuit, unor eventuale reacții cu încărcătură polemică.
} 
Ciută, Ciută 2015

Ciută et al. 2016

Colesniuc 2014

Coltofean 2016

Diaconescu 2014a

Diaconescu 2014b

Diaconescu 2014c

Diaconescu 2017

Diaconescu, Nițu, Suciu în press

Draşovean 1996

Drașovean 2014

Draşovean, Rotea 1986

Dumitrescu 1984

Dumitrescu-Chioar,

Luca, Suciu 2014

Florescu 2007

Furholt 2008a

Furholt 2008b

Garašanin 1951

Garašanin 1979

Garašanin 1982

Garašanin 1993
Ciută, M. M., Ciută, E. B., New considerations about Neolithic development habitation in the archaeological site Limba-Oarda de Jos (Alba county), Acta Terrae Septemcastrensis, XIV, 2015, 49-83

Ciută, M. M.,Totoianu, R., Şuteu, C., Codrea, II., Ciută, B., Bobînă, B., Bărbat, A., Consideraţii preliminare privind cercetările preventive din situl nr. 6, aparţinând lotului 1 al autostrăzii Sebeş-Turda (jud. Alba), Terra Sebus. Acta Musei Sabesiensis, 8, 2016, 9-22.

Colesniuc, S. M., Cultura Zau, Editura Ex Ponto: Constanța, 2014.

Coltofean, L., Zsófia Torma și așezarea de la Turdaș, punctul Luncă, județul Hunedoara, Teză de doctorat, manuscris nepublicat, Universitatea Lucian Blaga Sibiu, 2016.

Diaconescu, D., Despre cultura Turdaș şi poziţia sa cronologică, Analele Banatului S. N., XXII, 2014, 69-90.

Diaconescu, D., Considerations concerning the chronology of the Early Copper Age Tiszapolgár culture, Praehistorische Zeitschrift, 89 (2), 2014, 219-241.

Diaconescu, D., Remarks on the chronology of the Lengyel culture in the western half of the Carpathian Basin based on the analysis of funerar assemblages, Praehistorische Zeitschrift, 89 (1), 2014, 12-39.

Diaconescu, D., Despre cronologia absolută a unui nivel din situl neolitic de la Tărtăria-Gura Luncii, Analele Banatului, XXV, 2017, 25-33.

Diaconescu, D., Nițu, F. M., Suciu, C. I., The early Vinča culture in Transylvania. Considerations regarding its chronological position from the correspondence analysis perspective, in LBK and Vinča. Formation and transformation of Early Neolithic Lifestyles in Europe in the second half of the 6th millenium BC, Tübingen, 21-23 March, 2019, https://doi.org/10.1016/j.quaint.2020.05.019.

Draşovean, F., Cultura Vinča târzie (faza C) în Banat, Bibliotheca Historica et Archaeologica Banatica, I: Timișoara, 1996.

Draşovean, F., Despre cronologia relativă și absolută a neoliticului și eneoliticului timpuriu din răsăritul Bazinului Carpatic. O abordare Baesiană, Analele Banatului S. N., XXII, 2014, 33-67.

Drașovean, F., Rotea, M., Așezarea neolitică de la Șoimuș. Contribuții la problemele neoliticului târziu din sud-vestul Transilvaniei, Apulum, XXIII, 1986, 9-24.

Dumitrescu, H., Cercetările arheologice de la Tăualaş-Deva (partea I), Acta Musei Napocensis, XXI, 1984, 4-44.

Dumitrescu-Chioar, F., Luca, S. A.; Suciu, C. I., Excavations from 2010 at TărtăriaGura Luncii, Alba County, in J. Marler (ed.), Fiftty Years of Tărtăria Excavations. Festschrift in Honor of Gheorghe Lazarovici, Institute of Archaeomythology Sebastopol, Editura Suceava: Suceava, 2014, 28-34.

Florescu, C., Vinča culture, A history lesson. Pottery manufacturing 8000 years ago: exibition catalogue, Aeternitas: Alba Iulia, 2007, 31-41.

Furholt, M., Pottery, cultures, people? The European Baden material re-examined, Antiquity, 82, 2008, 617-628.

Furholt, M., Die Złota-Gruppe in Kleinpolen: Ein Beispiel für die Transformation einen Zeichensystems?, Germania, 86, 2008, 1-27.

Garašanin, M., Hronologija Vinčanske Gruppe, $\mathrm{PhD}$ dissertation at the University of Ljubljana, 1951.

Garašanin, M., Centralnobalkanska zona, Praistorija Jugoslavenskih Zemalja II. Neolitisko doba, Sarajevo, 1979, 79-212.

Garašanin, M., The Stone Age in the Central Balkan Area, J. Boardman, I. Edwards, N. Hammond, E. Sollberger (eds.), The Cambridge Ancient History, 1982, 75-135.

Garašanin, M., Zu den Problemen der Vinča-Gruppe in Rumänien, Balcanica, XXIV, 1993, 7-20. 
Ghenescu, Sana, Ștefu 2000

Gligor 2007a

Gligor 2007b

Gligor 2009

Holste 1939

Horedt 1949

Ignat 1982

Ignat 1999-2000

Ileș 2018

Kalicz, Makkay 1977

Lazarovici 1979

Lazarovici 1991a

Lazarovici 1991b

Lazarovici 1991c

Lazarovici 1991d

Lazarovici 1991e

Lazarovici 1991f

Lazarovici 2009

Lazarovici 2010

Lazarovici 2014

Lazarovici, Lazarovici 2006
Ghenescu, O., Sana, D., Ștefu, V., Cercetări arheologice de suprafață în sectorul Vințu de Jos-Tărtăria (jud. Alba), Buletinul Cercurilor Științifice Studențești, 6, 2000, 69-85.

Gligor, M., Situl arheologic de la Alba Iulia-Lumea Nouă. Istoricul cercetărilor, Annales Universitatis Apulensis, Series Historica, 11/I, 2007, 161-178.

Gligor, M., Lumea Nouă cultural group, in A history lesson. Pottery manufacturing 8000 years ago: exibition catalogue, Aeternitas: Alba Iulia, 2007, 43-49.

Gligor, M., Așezarea neolitică și eneolitică de la Alba Iulia-Lumea Nouă în lumina noilor cercetări, Editura Mega: Cluj-Napoca, 2009.

Holste, F., Zur chronologischen Stellung der Vinča-Keramik, Wiener Prähistorische Zeitschrift, XXVI, (2), 1939, 1-21.

Horedt, K., Săpături privitoare la epoca neo şi eneolitică, Apulum, III, 1949, 44-69.

Ignat, D., Un aspect mai puțin cunoscut în cadrul ceramicii pictate din nord-vestul României, Crisia, XII, 1982, 361-370.

Ignat, D., An overview of the neolithic of Crișana, Analele Banatului S. N., VII-VIII, 1999-2000, 13-33.

Ileș, A. I., Plastica antropomorfă și zoomorfă neolitică și eneolitică din Transilvania, Teză de doctorat, Manuscris nepublicat, Universitatea 1 Decembrie 1918 Alba Iulia, 2018.

Kalicz, N.,Makkay, J., Die Linienbandkeramik in der grossen Ungarischen Tiefebene, Studia Archaeologica VII, Budapest, 1977

Lazarovici, G., Neoliticul Banatului, Bibliotheca Musei Napocensis IV, Cluj-Napoca, 1979.

Lazarovici, G., Așezarea și grupul Bucovăț, Timișoara, 1991.

Lazarovici, G., Aspectul Tăulaș, in Gh. Lazarovici, F. Drașovean (eds.), Cultura Vinča în România. Origine, evoluţie, legături, sinteze, Comisia Muzeelor şi Colecţiilor: Timişoara, 1991, 115-121.

Lazarovici, G., Grupul și stațiunea Iclod, Muzeul de Istorie al Transilvaniei: ClujNapoca, 1991.

Lazarovici, G., Grupul Lumea Nouă, in Gh. Lazarovici, F. Drașovean (eds.), Cultura Vinča în România. Origine, evoluție, legături, sinteze, Comisia Muzeelor şi Colecţiilor: Timișoara, 1991, 111-114

Lazarovici, G., Complexul Cluj-Cheile Turzii-Lumea Nouă-Iclod, in Gh. Lazarovici, F. Drașovean (eds.), Cultura Vinča în România. Origine, evoluție, legături, sinteze, Comisia Muzeelor şi Colecţiilor: Timișoara, 1991, 100-102.

Lazarovici, G., Cultura Banatului, in Gh. Lazarovici, F. Draşovean (eds.), Cultura Vinča în România. Origine, evoluție, legături, sinteze, Comisia Muzeelor şi Colecţiilor: Timişoara, 1991, 32-40.

Lazarovici, G., The Zau culture, in F. Drașovean, D. L. Ciobotaru, M. Maddison (eds.), Ten years after: the Neolithic of the Balkans, as uncovered by the last decade of research, Bibliotheca Historica et Archaeologica Banatica, XLIX, Timișoara, 2009, 179-217.

Lazarovici, G., Evolution, absolute and relative chronology of the Zau culture, in J. Šuteková, P. Pavúk, P. Kalábková, B. Kovár (eds.), Panta Rhei. Studies on the Chronology and Cultural Developmnet of South-eastern and Central Europe in Earlier Prehistory: presented to Juraj Pavik on the Occasion of his 75th Birthday, Studia Archaeologica et Mediaevalia Bratislava, XI, 2010, 115-128.

Lazarovici, G., Cronologia absolută, relativă și evoluţia culturii Zau, in S. M. Colesniuc, Cultura Zau, Editura Ex Ponto: Constanța, 2014, 15-32.

Lazarovici, C.-M., Lazarovici, G., Arhitectura Neoliticului și Epocii Cuprului din România. I. Neoliticul, Bibliotheca Archaeologica Moldaviae, IV, Iași, 2006. 
Lazarovici, Lazarovici 2015

Lazarovici, KalmarMaxim 1991a

Lazarovici, KalmarMaxim 1991b

Lazarovici, Maxim 1991

Lazarovici, Maxim 1996

Lazarovici, Németi 1983

Lazarovici, Lazarovici, Merlini 2011

Luca 1986

Luca 1995-1996

Luca 1997

Luca 1999

Luca 2001

Luca 2008

Luca 2006a

Luca 2006b

Luca 2009

Luca 2016

Luca, Părean 1995-1996

Luca et al. 2000

Luca, Roman, Diaconescu 2004
Lazarovici, G., Lazarovici, C.-M., Chronological and cultural correlations between Neolithic and Copper Age civilizations of Central and North Transylvania and East Alföld area, în C. Virag (ed.), Neolithic cultural phenomena in the Upper Tisa Basin, Editura Muzeului Sătmărean: Satu-Mare, 2015, 7-28.

Lazarovici, G., Kalmar-Maxim, Z., Vinča în Transilvania, în Gh. Lazarovici, F. Draşovean (eds.), Cultura Vinča în România. Origine, evoluție, legături, sinteze, Comisia Muzeelor şi Colecţiilor: Timişoara, 1991, 93-99.

Lazarovici, G., Kalmar-Maxim, Z., Aspectul Turdaş, în Gh. Lazarovici, F. Drașovean (eds.), Cultura Vinča în România. Origine, evoluție, legături, sinteze, Comisia Muzeelor şi Colecţiilor: Timișoara, 1991, 122-132.

Lazarovici, G., Maxim, Z., Tărtăria, Muzeul de Istorie al Transilvaniei: Cluj-Napoca, 1991.

Lazarovici, G., Maxim, Z., Marton Roska’ excavation from Turdaș and their results, în F. Draşovean (ed.), The Vinča culture, its role and cultural connections, Bibliotheca Historica et Archaeologica Banatica, II,Timișoara, 1996, 223-267.

Lazarovici, G., Németi, I., Neoliticul dezvoltat din nord-vestul României (Sălajul, Sătmarul și Clujul), Acta Musei Porolissensis, VII, 1983, 17-60.

Lazarovici, G., Lazarovici, C.-M., Merlini, M., Tărtăria and the sacred tablets, Editura Mega: Cluj-Napoca, 2011.

Luca, S. A., Discuții asupra materialului ceramic din stațiunea neolitică de la LipovaHodaie, Apulum, XXIII, 1986, 43-53.

Luca, S. A., Die Vinča-Siedlung aus Rumess. Die A-Phase der Vinča-Kultur în Siebenburgen, Sargetia, XXVI/1, 1995-1996, 45-62.

Luca, S.A., Aşezări neolitice pe Valea Mureşului I. Habitatul turdăşean de la OrăştieDealul Pemilor (punct X2), Bibliotheca Musei Apulensis IV, Alba Iulia, 1997.

Luca, S. A., Aspecte ale neoliticului și eneoliticului din sudul și sud-vestul Transilvaniei, Apulum, XXVI, 1999, 5-33.

Luca, S. A., Aşezări neolitice pe Valea Mureşului II. Noi cercetări arheologice la Turdaş-Luncă. I Campaniile anilor 1992-1995, Bibliotheca Musei Apulensis XVII, Alba Iulia, 2001.

Luca, S. A., The Neolitihic and Eneolithic Periods in Tranylvania, in J. Marler (ed.), The Danube script: Neo-Eneolithic Writing in South-Eastern Europe: exhibition catalog, Institute of Archaeomythology Sebastopol, Brukenthal National Museum: Sibiu, 2008, 23-38.

Luca, S. A., Aspects of the neolithic and eneolithic periods in Transylvania (II), in N. Tasić, C. Grozdanov (eds.), Homage to Milutin Garašanin, Serbian Academy of Sciences and Arts: Belgrade, 2006, 341-366.

Luca, S. A., Aspecte ale neoliticului și eneoliticului din Transilvania (II), Corviniana, X, 2006, 11-44.

Luca, S. A., Issues in defining the Foeni-Mintia cultural group in Transylvania, in V. Cotiugă, F. Tencariu, G. Bodi (eds.), Itinera in praehistoria. Studia in honorem magistri Nicolae Ursulescu quinto a sexagesimo anno, Editura Universităţii „Alexandru Ioan Cuza”: Iași, 2009, 199-210.

Luca, S. A., Tărtăria rediviva, Bibliotheca Brukenthal, LXXI, Alba Iulia, 2016.

Luca, S. A., Părean, I., Descoperiri arheologice în hotarul comunei Orlat (jud. Sibiu), Sargetia, XXVI/1, 1995-1996, 227-232.

Luca, S. A., Ciugudean, H., Roman, C. C., Dragotă, A., Faza timpurie a culturii Vinča în Transilvania. Repere ale orizontului cronologic şi etnocultural, Angustia, 5, 2000, $37-72$.

Luca, S. A., Roman, C., Diaconescu, D., Cercetări arheologice în peștera Cauce, Volumul 1. Bibliotheca Septemcastrensis, IV, Sibiu, 2004. 
Luca et al. 2006

Luca et al. 2007

Luca, Diaconescu, Suciu 2008

Luca et al. 2008a

Luca et al. 2008b

Luca, Diaconescu, Suciu 2011

Luca et al. 2013

Luca et al. 2016

Luca et al. 2017a

Luca et al. $2017 \mathrm{~b}$

Luca et al. 2018

Luca et al. 2019

Maxim 1999

Mazăre 2005

Milojčić 1949a

Milojčić 1949b

Müller 2009

Németi 1986-1987
Luca, S. A., Diaconescu, D.,Georgescu, A., Suciu, C., Cercetările arheologice de la Miercurea Sibiului-Petriş (jud. Sibiu). Campaniile anilor 1997-2005, Brukenthal Acta Musei, I.1, 2006, 9-21.

Luca, S. A., Diaconescu, D., Georgescu, A., Suciu, C., Archaeological researches at Miercurea Sibiului-Petriș (Sibiu-county, Romania). The campaigns from 1997 to 2005, Acta Terrae Septemcastrensis, VI, 2007, 7-23.

Luca, S. A.; Diaconescu, D., Suciu, C., Archaeological research in Miercurea Sibiului-Petriș (Sibiu County, Romania): the Starčevo-Criș level during 1997-2005 (a preliminary report). în Documenta Praehistorica, XXXV, 2008, 325-343.

Luca, S. A., Beldiman, C., Biagi, P., Ciută, B., Ciută, M.M., Diaconescu, D., Georgescu A., El Susi, G., Spataro, M., Suciu, C., Miercurea Sibiului, com. Miercurea Sibiului, jud. Sibiu. Punct: Petriş, CCA. Campania 2007, 2008, 199-200.

Luca, S. A., Suciu, C. I., Diaconescu, D., Niţu, F. M., Şeulean, A., Contribuţii la repertoriul arheologic al judeţului Sibiu. O nouă aşezare vinčiană timpurie la Miercurea Sibiului-Pustia (Luncă), Buridava, VI, 2008, 20-29.

Luca, S. A.; Diaconescu, D., Suciu, C., A ceramic import from Neolithic discovered at Miercurea Sibiului-Petriş, Sibiu county, Brukenthal Acta Musei, VI.1, 2011, 23-34.

Luca, S. A., Georgescu, A., Natea, G.V.,Teodorescu, M. R.,Urduzia, C., Munteanu, C. I., Palaghie, V., Luca, A., Cercetarea preventivă. Provocarea arheologică a zilelor noastre, Bibliotheca Brukenthal LXV, Sibiu, 2013.

Luca, S. A., Sava, B. T., Păceșilă, D., Gaza, O., Stanciu, I., Sava, G., Ştefan, B., Radiocarbon data for level III from Tărtăria-Gura Luncii (preventive researches from 2014-2015), Brukenthal Acta Musei, XI.1, 2016, 11-15.

Luca, S. A., Dumitrescu-Chioar, F., Sava, B. T., Păceșilă, D., Gaza, O., Stanciu, I., Sava, G., Ștefan, B., Date radiocarbon din situl arheologic de la Turdaș-Luncă (Cercetările preventive ale anului 2011) (II), Analele Banatului S.N., XXV, 2017, 35-39.

Luca, S. A., Sava, B.T., Păceșilă, D. Gaza, O., Stanciu, I., Sava, G., Ștefan, B., Date radiocarbon din situl arheologic de la Turdaş-Luncă (cercetările preventive ale anului 2011) (I), Apulum, LIV, 2017, 137-146.

Luca, S. A., Dumitrescu-Chioar, F., Sava, B. T., Păceșilă, D., Gaza, O., Stanciu, I., Sava, G., Ștefan, B., Radiocarbon data from the Turdaş-Luncă archaeological site. Petreşti culture (preventive research of 2011) (II), Acta Terrae Septemcastrensis, XVII, 2018, 115-120.

Luca, S. A., Sava, B. T., Păceșilă, D., Gaza, O., Stanciu, I., Sava, G., Ștefan, B., Date radiocarbon din situl arheologic de la Turdaş-Luncă (Cercetările preventive ale anului 2011) (III), Apulum, LVI, 2019, 1-15.

Maxim, Z., Neo-eneoliticul din Transilvania, Bibliotheca Musei Napocensis XIX, Cluj-Napoca, 1999.

Mazăre, P., Artefacte din os descoperite în așezarea neolitică de la Limba (jud. Alba), în C. Popa, G. Rustoiu (eds.), Omagiu profesorului Ioan Andrițoiu cu prilejul implinirii a 65 de ani. Studii și cercetări Arheologice, Editura „Altip”: Alba Iulia, 2005, 237-312.

Milojčić, V., Chronologie der jüngeren Steinzeit Mittel- und Südosteuropas, Gebr. Mann: Berlin, 1949.

Milojčić, V., South-eastern elements in the prehistoric civilization of Serbia, The Annual of the British School at Athens, 44, 1949, 258-306.

Müller, J., Dating the Neolithic: methodological premises and absolute chronology, Radiocarbon, 51 (2), 2009, 721-736.

Németi, I., Descoperiri din neoliticul târziu în Valea Crasnei, Satu-Mare. Studii și Comunicări, VII-VIII, 1986-1987, 15-61. 
Nițu 2008

Nițu 2012a

Nițu 2012b

Nițu 2014

Paul 1960

Paul 1965

Paul 1981

Paul 1992

Paul 2011

Popa 2000

Popa 2011

Popa, Totoianu 2001

Reimer et al. 2013

Rogozea 2016

Rogozea 2017

Roman 2008

Roska 1941

Rustoiu 2001

Schier 1995
Nițu, F. M., Cataloage tipologice privind cultura Vinča, faza timpurie, Corviniana, XII, 2008, 29-54.

Nițu, F. M., Aspecte tehnologice privind ceramica culturii Vinča din Transilvania, Teză de doctorat. Manuscris nepublicat, Sibiu, 2012.

Nițu, F. M., Turdaș culture pottery from Turdaș-Luncă site. Typological and morphological analysis. A case study, Acta Terrae Septemcastrensis, XI, 2012, 57-84.

Nițu, F. M., Așezarea Vinča de la Ocna Sibiului-Fața Vacilor (jud. Sibiu). Un studiu tehnologic și morfologic asupra ceramicii, in C.E. Ștefan, M. Florea, S. C. Ailincăi, C. Micu (eds.), Studii privind preistoria sud-estului Europei. Volum dedicate memoriei lui Mihai Șimon, Institutul de cercetari Eco-Muzeale „Gavrila Simion”, Editura Istros: Brăila, 2014, 77-130.

Paul, I., Așezarea neolitică tîrzie de la „Poiana în Pisc”, Materiale și Cercetări Arheologice, VII, 1960, 107-120.

Paul, I., Unele probleme ale neoliticului din Transilvania în legătură cu cultura Petrești, Revista Muzeelor, 4, (II), 1965, 294-301.

Paul, I., Die gegenwärtige Forschungsstand zur Petrești-Kultur, Praehistorische Zeitschrift, 56, 1981, 197-234.

Paul, I., Cultura Petreşti, Editura Museion: Bucureşti, 1992.

Paul, I., Enigma Tăbliţelor de la Tărtăria-schiță preliminară, Conferințele Bibliotecii Astra, 130, Sibiu, 2011, 9-73.

Popa, C. I., Descoperiri neolitice timpurii în bazinul hidrografic al Cugirului (jud. Alba), Banatica, 15/I, 2000, 17-47.

Popa, C. I., Valea Cugirului din preistorie până în zorii epocii moderne, Editura Mega: Cluj-Napoca, 2011.

Popa, C. I., Totoianu, R., Date noi asupra locuirilor umane de la Sebeș-Podu Pripocului (jud. Alba), Patrimonium Apulense, I, 2001, 33-54.

Reimer, P. J., Bard, E., Bayliss, A., Beck, J. W., Blackwell, P. G., Bronk Ramsey, C., Grootes, P. M., Guilderson, T. P., Haflidason, H., Hajdas, I., Hatt, C., Heaton, T. J., Hoffmann, D. L., Hogg, A. G., Hughen, K. A., Kaiser, K. F., Kromer, B., Manning, S. W., Niu, M., Reimer, R. W., Richards, D. A., Scott, E. M., Southon, J. R., Staff, R. A., Turney, C. S. M., van der Plicht, J., IntCal13 and Marine13 Radiocarbon Age Calibration Curves 0-50,000 Years cal BP, Radiocarbon, 55(4), 2013, 1869-1887.

Rogozea, O.-C., Un semibordei atribuit fazei A3 a culturii Vinča descoperit la Tărtăria (com. Săliștea, jud. Alba), in D. Micle, A. Stavilă, C. Oprean, S. Forțiu (eds.), ArheoVest, Interdisciplinaritate in Arheologie și Istorie, IV/1, In Honorem Prof. Univ. Dr. Adrian Bejan, Timişoara, 26 Noiembrie 2016, Universitatea de Vest din Timișoara, JATEPress Kiadó, Szeged, 2016, 121-161.

Rogozea, O.C., Discoveries attributed to the early Vinča phase in Tărtăria „Gura Luncii" (Alba County). The 214 preventive archaeological researches performed on „Site 10B”, Ziridava. Studia Archaeologica, 31, 2017, 7-28.

Roman, C. C., Habitatul uman în peșterile din sud-vestul Transilvaniei, Bibliotheca Brukenthal, XXV, Sibiu, 2008.

Roska, M., A Torma Zsófia - Gyüjtemény az Erdély Nemzeti Múzeum éremés régiségtárában (Die Sammlung Zsófia von Torma in der numismatischarchaeologischen Abteilung des siebenbürgischen Nationalmuseums), Minerva ClujNapoca, 1941.

Rustoiu, G., Așezarea de la Oarda-Dublihan (mun. Alba Iulia), Patrimonium Apulense, I, 2001, 55-70.

Schier, W., Vinca studien. Tradition und Innovation im Spätneolithikum des zentralen Balkanraumes am Beispiel der Gefässkeramik aus Vinča-Belo Brdo, Teză de habilitare. Manuscris nepublicat, Universitatea Heidelberg, 1995. 
Schier 1996

Schier 2000

Schmidt 1903

Suciu 2009

Ştefan, Petcu, Petcu 2013

Torma 1879

Vasić 1910

Vasić 1936

Virag 2004

Virag 2007

Vlassa 1963

Vlassa 1967

Vlassa 1976

Whittle et al. 2016
Schier, W., The relative and absolute chronology of Vinča: new evidence from the type site, în F. Drașovean (ed.), The Vinča culture, its role and cultural connections, Editura Mirton, Timișoara, 1996, 141-162.

Schier, W., Measuring Change: the Neolithic Pottery Sequence of Vinča-Belo Brdo, Documenta Praehistorica, XXVII, 2000, 187-197.

Schmidt, H., Tordos, Zeitschrift für Ethnologie, 35, H. 2/3, 1903, 438-469.

Suciu, C.I., Cultura Vinča în Transilvania, Bibliotheca Brukenthal XLIV, Alba Iulia, 2009.

Ștefan, C.E., Petcu, R., Petcu, R., Reprezentări antropomorfe din așezarea neolitică de la Șoimuș - La Avicola (Ferma 2), jud. Hunedoara, Studii de Preistorie, 10, 2013, 49-66.

Torma, Z., Neolith kőkorszakbeli telepek Hunyadmegyében, Erdélyi Múzeum, VI, 7, 193-211.

Vasić, M., Die Hauptergebnisse der prähistorischen Ausgrabung in Vinča im Jahre 1908, Praehistorische Zeitschrift, 2 (1), 1910, 23-29.

Vasić, M., Preistoriska Vinča III. Plastika, terakote, Državne Štamparije: Beograd, 1936.

Virag, C., Cercetări arheologice la Urziceni-Vamă, Acta Musei Porolissensis, XXVI, 2004, 41-76.

Virag, C., Materiale ceramice neolitice de la Blaja-Grind Cehal, în V. Ciubotă; T. Nicoară; M. Vegheş; L.-I. Horvat (eds.), Relaţii româno-ucrainene. Istorie şi contemporaneitate, Presa Universitară Clujeană: Cluj-Napoca, Editura Muzeului Sătmărean, Satu Mare, 2007, 27-42.

Vlassa, N., Chronology of the Neolithic in Transylvania in the Light of the Tărtăria Tablets, Dacia. Revue d'archéologie et d'histoire ancienne - Nouvelle Série, VII, 1963, 485-494.

Vlassa, N., Unele probleme ale neoliticului din Transilvania, Acta Musei Napocensis, IV, 1967, 403-423.

Vlassa, N., Neoliticul Transilvaniei. Studii, articole, note, Bibliotheca Musei Napocensis, III, Cluj-Napoca, 1976.

Whittle, A., Bayliss, A., Barclay, A., Gaydarska, B., Bánffy, E., Borić, D., Drașovean, F., Jakucs, J., Marić, M., Orton, D., Pantović, I., Schier, W., Tasić N., Vander Linden, M., A Vinča potscape formal chronological models for the use and development of Vinča ceramics in south-east Europe, Documenta Praehistorica, XLIII, 2016, 1-60.

\section{LIST OF ILLUSTRATIONS}

Figure 1. The absolute cronological position of the layers belonging to Turdaș and Petrești cultures from TurdașLuncă site (processed after Whittle et al. 2016, fig. 37).

Figure 2. The map of the sites belonging to the early Vinča culture in Transylvania: 1) Râpaş; 2) Romos; 3) Balomiru de Câmp; 4) Tărtăria; 5) Vurpăr; 6) Oarda de Jos; 7) Limba; 8) Șeușa; 9) Alba Iulia; 10) Sântimbru; 11) Aiud; 12) Sebeș Alba; 13) Miercurea Sibiului; 14) Ocna Sibiului; 15) Orlat; 16) Șoimuș.

Figure 3. The disposal of the sites from Tărtăria: 1. Gura Luncii; 2. Gura Luncii/Gura Văii Cioarei; 3. Pietroșița.

Figure 4. The map of the Miercurea Sibiului - Petriș site position and the detailed plan of the research units disposal from 2001-2010 research campaigns (marked with yellow).

Figure 5. The spatial distribution of the features belonging to Vinča culture and introduced into the CA. Light-blue designates the features from the layer IIa1, black indicates the features attributed to the layer IIa2, green shows the features assingned to the layer IIb, purple for the features from the layer II/III. With red labels are indicating the 
features that were not integratied in any of the layers from Miercurea Sibiului, level II.

Figure 6. a - The results of the CA applied on the Vinča features from Miercurea Sibiului, using the data from the already mentioned archaeological literature; $\mathrm{b}$ - The CA results for the level II from Miercurea Sibiului, showing also the $\mathrm{BP}$ value for the ${ }^{14} \mathrm{C}$ existing dates.

Figure 7. The Bayesian approach for the level II from Miercurea Sibiului, using the CA results as prior-estimates.

Figure 8. The absolute chronological chart of the Vinča culture and the positions of the $\sigma$ ranges for the stages IIA1 and IIA2 from Miercurea Sibiului (processed after Whittle et al. 2016, fig. 37).

Figure 9. The results of the CA applied on the research units/features from Miercurea Sibiului- Petriş and VinčaBelo Brdo (depth 9.3-6.5 m).

Figure 10. The CA results for the Vinča-Belo Brdo's research units, belonging to the early phases (a and B) of the Vinča culture.

Figure 11. The map of the Vinča - Belo Brdo site and of the Transylvanian sites which offered analysys units for the CA approach: 1) Vinča - Belo Brdo; 2) Tărtăria - Gura Luncii/Gura Văii Cioarei and Tărtăria - Pietroșița/site $10 b$; 3) Miercurea Sibiului - Petriş,; 4) Alba Iulia - Lumea Nouă.

Figure 12. The results of the $\mathrm{CA}$ applied on the features/research units belonging to four tranylvanian sites and to the Vinča - Belo Brdo site.

Figure 13. The results of the CA applied on the analysis units from quadrants I and IV of the graphic from fig. 12

Figure 14. The catalogue of the decorative motifs for the Vinča culture's pottery.

Figure 15. The catalogue of the decorative motifs for the Vinča culture's pottery.

Figure 16. The catalogue of the upper parts (rims) of the Vinča culture's pottery.

Figure 17. The catalogue of the upper parts (rims) of the Vinča culture's pottery.

Figure 18. The catalogue of the upper parts (rims) of the Vinča culture's pottery.

Figure 19. The catalogue of pots' shapes of the Vinča culture's pottery.

DRAGOȘ DIACONESCU, Muzeul Național al Banatului, secția Arheologie, str. Martin Luther, nr. 4, 300054, Timișoara, România, goshu_d@yahoo.com.

COSMIN IOAN SUCIU, Cercetător independent, Timișoara, România, cos_suciu@yahoo.com. 


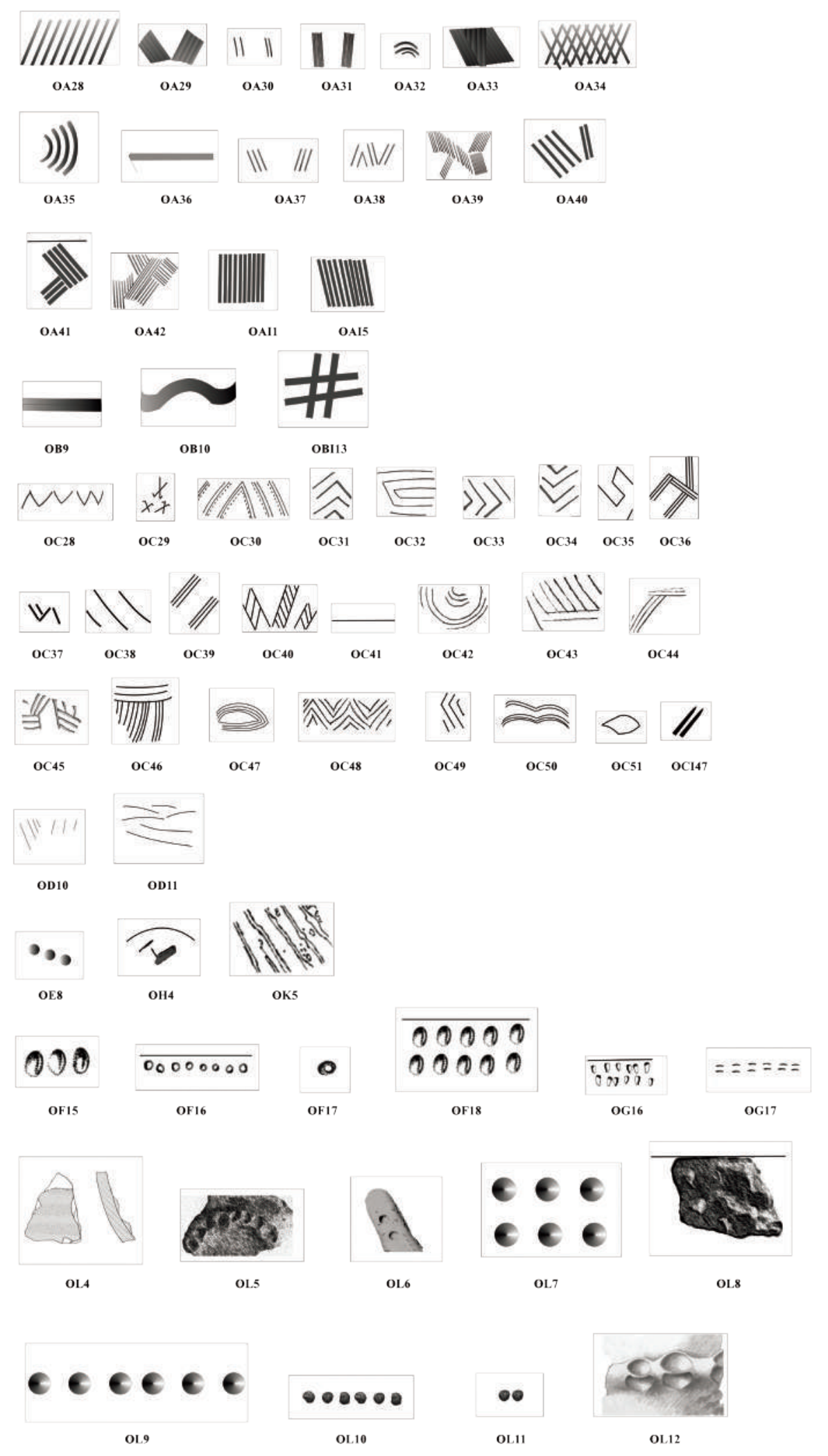

Figura 14. Catalog ornamente ceramică cultura Vinča. 



OP74

OPC1
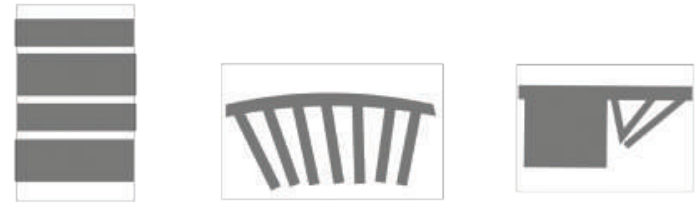

OR2

OR3

ORI3
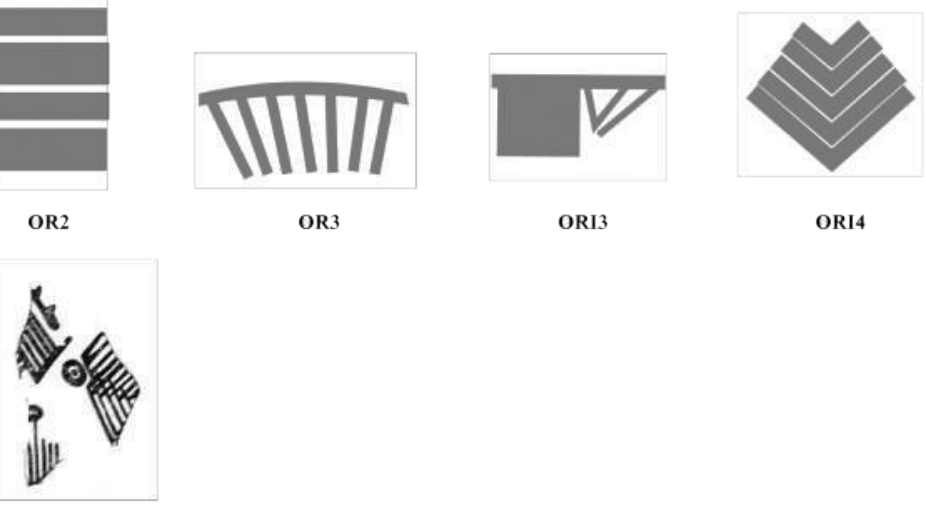

os1

Figura 15. Catalog ornamente cultura Vinča. 

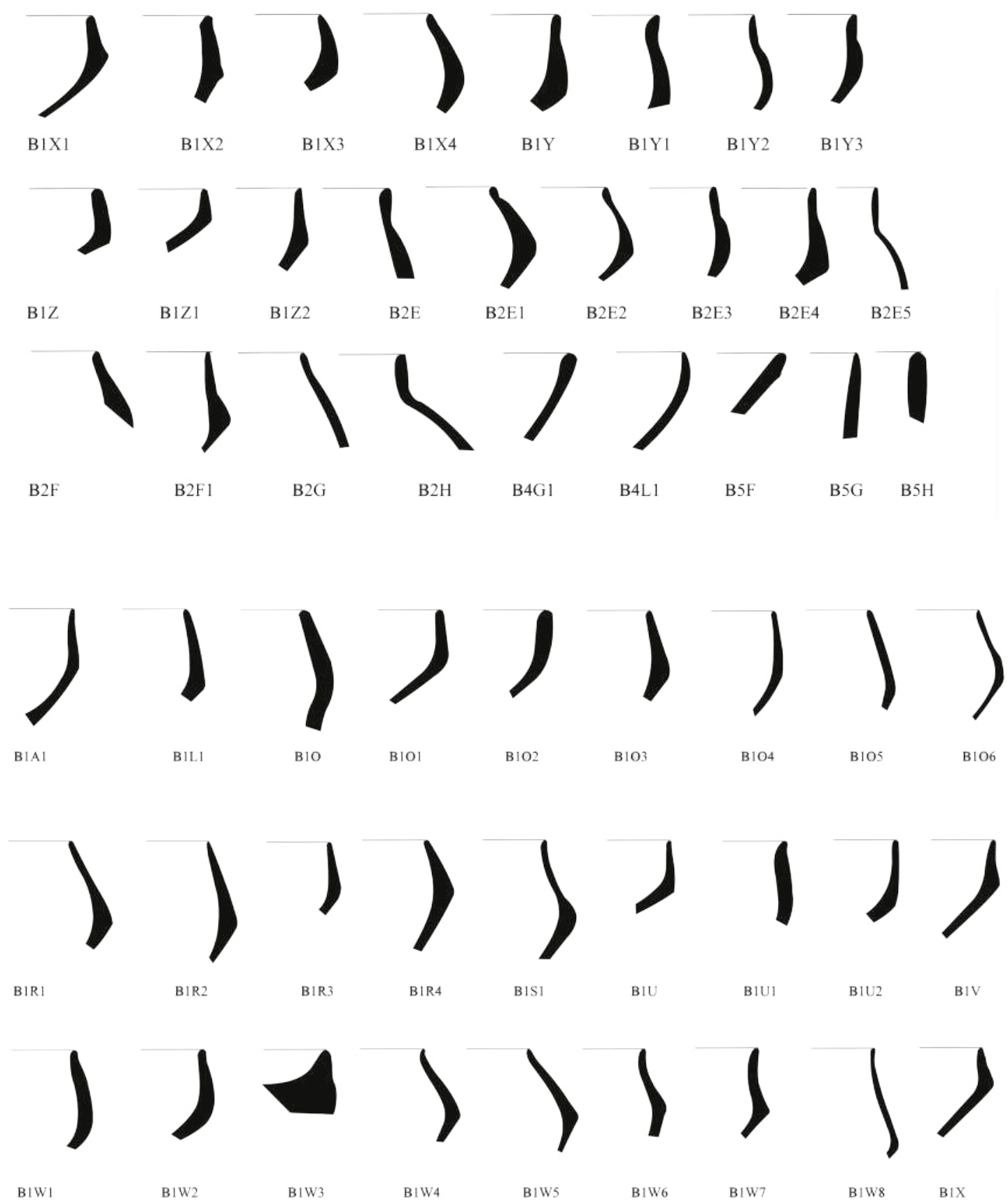

Figura 16. Catalog buze de vas cultura Vinča. 


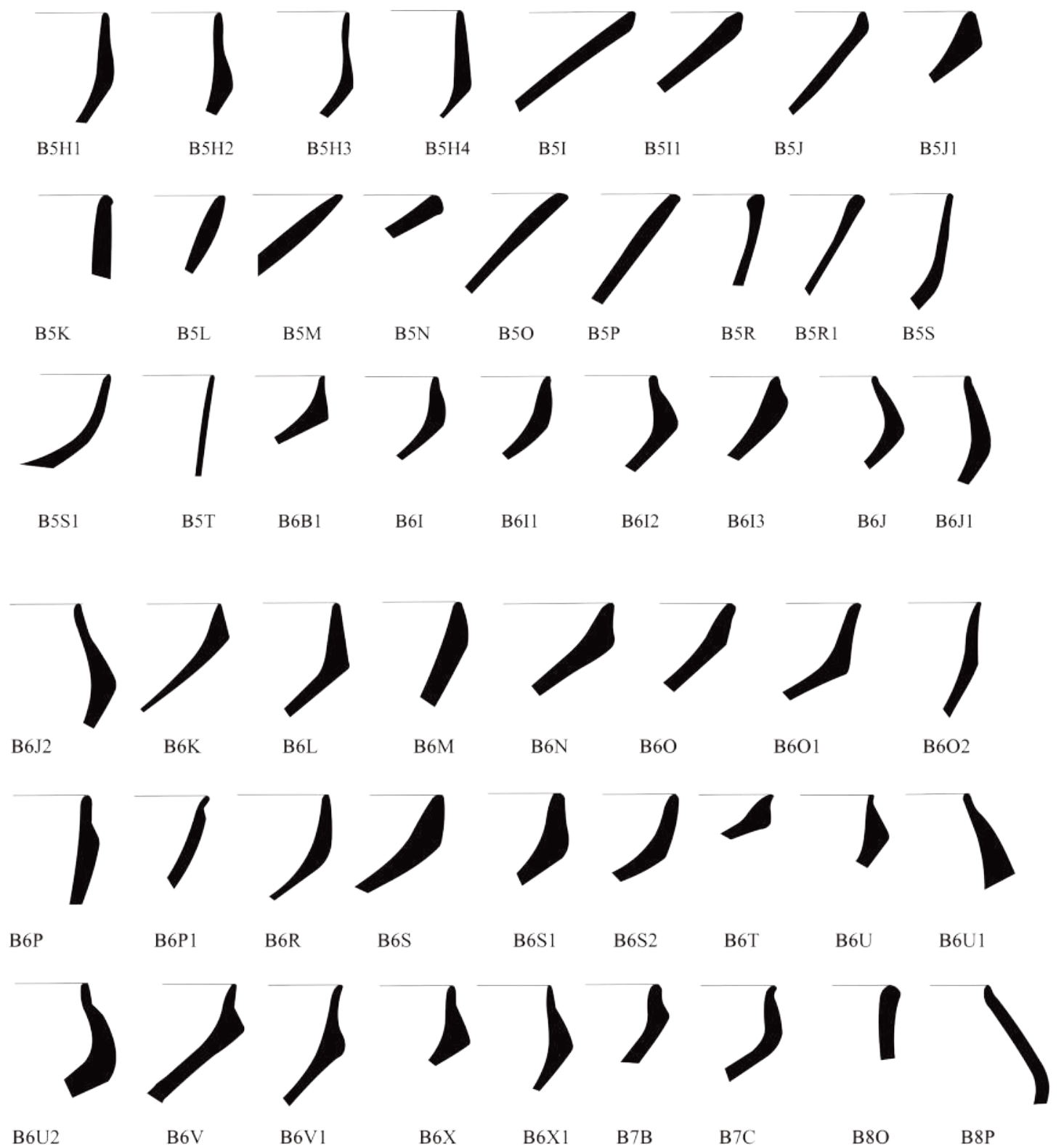

Figura 17. Catalog buze de vas cultura Vinča. 


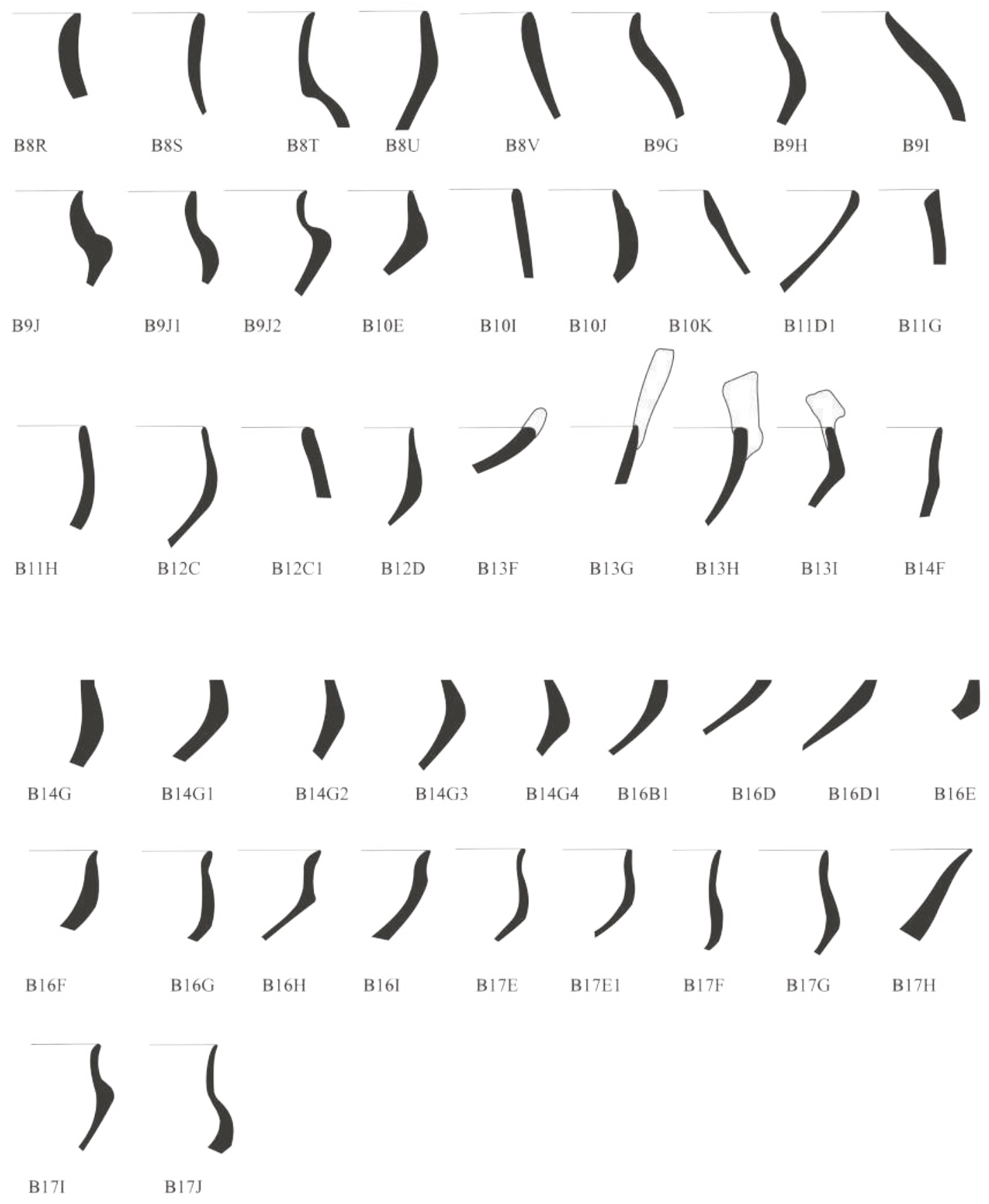

Figura 18. Catalog buze de vas cultura Vinča. 


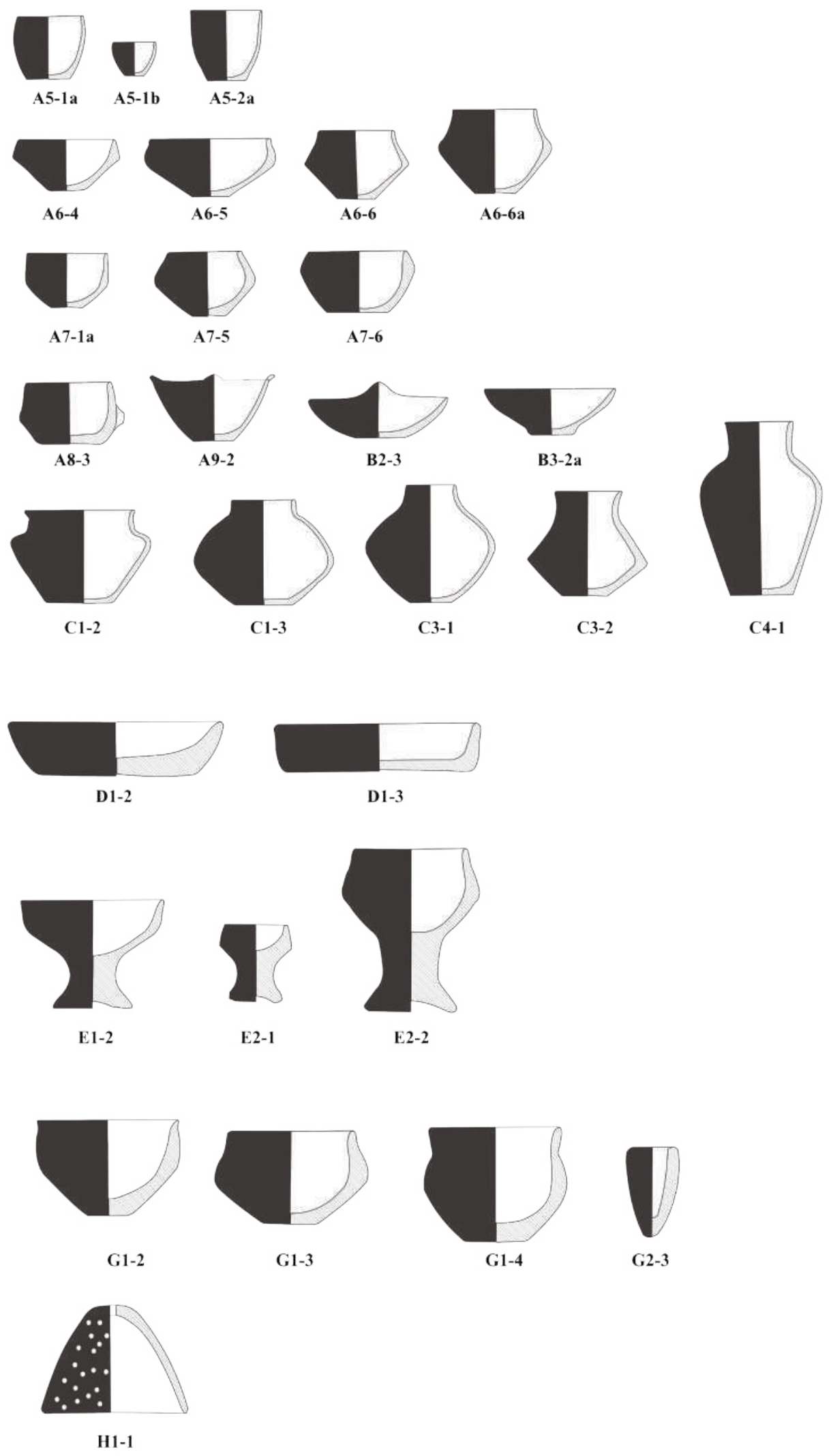

Figura 19. Catalog forme de vas cultura Vinča. 